[Supporting Information]

\title{
Constructing Crystalline Covalent Organic Frameworks from Chiral Building Blocks
}

\author{
Hai-Sen $\mathrm{Xu}^{\dagger}{ }^{\dagger}$ San-Yuan Ding, ${ }^{*}{ }^{\dagger}$ Wan-Kai An, ${ }^{\dagger}$ Han $\mathrm{Wu}^{\dagger}{ }^{\dagger}$ and Wei Wang ${ }^{*, \dagger}$, \\ † State Key Laboratory of Applied Organic Chemistry, College of Chemistry and \\ Chemical Engineering, Lanzhou University, Lanzhou, Gansu 730000, China \\ ${ }^{\ddagger}$ Collaborative Innovation Center of Chemical Science and Engineering, Tianjin \\ 300071, China \\ *E-mail:wang_wei@lzu.edu.cn; dingsy@lzu.edu.cn
}

1. Summary of Schemes, Figures, and Tables $\quad$ S2

2. General Information $\quad$ S4

3. Synthesis of Monomer 2, N-Boc-protected 3, Monomer 3, and DPBIP S5

4. Conversion of DPBIP under Solvothermal Conditions S9

5. Synthesis, Characterization, and Structural Modeling of LZU-70 S10

6. Synthesis, Characterization, and Structural Modeling of LZU-72-Boc and LZU-72 S20

7. Synthesis, Characterization, and Structural Modeling of LZU-76-Boc and LZU-76 S35

$\begin{array}{ll}\text { 8. Catalytic Activity Test of LZU-76 } & \text { S48 }\end{array}$

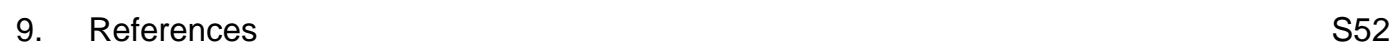

10. Liquid ${ }^{1} \mathrm{H}$ and ${ }^{13} \mathrm{C}$ NMR Spectra

11. HPLC Spectra $\quad S 62$ 


\section{Summary of Schemes, Figures, and Tables}

$\begin{array}{lll}\text { Scheme S1 Synthesis of LZU-70 } & \text { S10 }\end{array}$

Figure S1 FT-IR spectra of LZU-70, monomer 2, and monomer 4

Figure S2 $\quad{ }^{13} \mathrm{C}$ CP/MAS NMR spectrum of LZU-70 S11

Figure S3 PXRD patterns of LZU-70, monomer 2, and monomer $4 \quad \mathrm{~S} 12$

Figure S4 TGA data of LZU-70 $\quad$ S12

Figure S5 Nitrogen adsorption and desorption isotherms of LZU-70 S13

$\begin{array}{lll}\text { Figure S6 } & \text { BET surface area plot for LZU-70 } & \text { S13 }\end{array}$

$\begin{array}{lll}\text { Figure S7 } & \text { Langmuir surface area plot for LZU-70 } & \text { S14 }\end{array}$

$\begin{array}{llr}\text { Figure S8 Pore size distribution of LZU-70 } & \text { S14 }\end{array}$

Figure S9 Simulated nitrogen adsorption isotherm of LZU-70 $\quad$ S15

Figure S10 Simulated BET surface area plot for LZU-70 S15

Figure S11 SEM image of LZU-70 S16

Figure S12 TEM image of LZU-70

$\begin{array}{lll}\text { Figure S13 } & \text { Observed and calculated PXRD patterns of LZU-70 } & \text { S17 }\end{array}$

Figure S14 Experimental and Pawley-refined PXRD patterns of LZU-70 S18

Table S1 Fractional atomic coordinates for the unit cell of LZU-70 S19

Scheme S2 Synthesis of LZU-72-Boc and LZU-72 S20

Figure S15 FT-IR spectra of LZU-72-Boc, N-Boc-protected 3, and monomer $4 \quad$ S21

Figure S16 FT-IR spectra of LZU-72-Boc and LZU-72 S21

Figure S17 $\quad{ }^{13} \mathrm{C}$ CP/MAS NMR spectra of LZU-72-Boc and LZU-72 S22

Figure S18 PXRD patterns of LZU-72-Boc, N-Boc-protected 3, and monomer $4 \quad$ S23

Figure S19 PXRD patterns of LZU-72-Boc and LZU-72 S23

$\begin{array}{lll}\text { Figure S20 TGA data of LZU-72-Boc and LZU-72 } & \text { S24 }\end{array}$

Figure S21 Nitrogen adsorption and desorption isotherms of LZU-72-Boc $\quad$ S24

$\begin{array}{lll}\text { Figure S22 } & \text { BET surface area plot for LZU-72-Boc } & \text { S25 }\end{array}$

Figure S23 Langmuir surface area plot for LZU-72-Boc S25

Figure S24 Pore size distribution of LZU-72-BoC S26

Figure S25 Nitrogen adsorption and desorption isotherms of LZU-72 S26

$\begin{array}{lll}\text { Figure S26 } & \text { BET surface area plot for LZU-72 } & \text { S27 }\end{array}$

$\begin{array}{lll}\text { Figure S27 } & \text { Langmuir surface area plot for LZU-72 } & \text { S27 }\end{array}$

$\begin{array}{lll}\text { Figure S28 Pore size distribution of LZU-72 } & \text { S28 }\end{array}$

Figure S29 Single-crystal structure of $N$-Boc-protected $3 \quad S 29$

Figure S30 Simulated pore structures of LZU-72-Boc and LZU-72 S29

Figure S31 Simulated nitrogen adsorption isotherm of LZU-72 S30 
Figure S32 Simulated BET surface area plot for LZU-72 S30

Figure S33 SEM images of LZU-72-Boc S31

$\begin{array}{lll}\text { Figure S34 SEM images of LZU-72 } & \text { S31 }\end{array}$

Figure S35 TEM image of LZU-72-Boc S32

Figure S36 TEM image of LZU-72 S32

Figure S37 Observed and calculated PXRD patterns of LZU-72 S33

Table S2 Fractional atomic coordinates for the unit cell of LZU-72 S34

Scheme S3 Synthesis of LZU-76-Boc and LZU-76 S35

Figure S38 FT-IR spectra of LZU-76-Boc, N-Boc-protected 3, and monomer $5 \quad$ S36

Figure S39 FT-IR spectra of LZU-76-Boc and LZU-76 S36

Figure S40 $\quad{ }^{13} \mathrm{C}$ CP/MAS NMR spectra of LZU-76-Boc and LZU-76

Figure S41 PXRD patterns of LZU-76-Boc, $N$-Boc-protected 3, and monomer 5 S38

Figure S42 PXRD patterns of LZU-76-Boc and LZU-76 S38

Figure S43 TGA data of LZU-76-Boc and LZU-76 S39

Figure S44 Nitrogen adsorption and desorption isotherms of LZU-76-Boc S39

Figure S45 BET surface area plot for LZU-76-Boc $\quad$ S40

Figure S46 Langmuir surface area plot for LZU-76-Boc $\quad$ S40

$\begin{array}{lll}\text { Figure S47 Pore size distribution of LZU-76-Boc } & \text { S41 }\end{array}$

Figure S48 Nitrogen adsorption and desorption isotherms of LZU-76 $\quad$ S41

$\begin{array}{lll}\text { Figure S49 } & \text { BET surface area plot for LZU-76 } & \text { S42 }\end{array}$

Figure S50 Langmuir surface area plot for LZU-76 S42

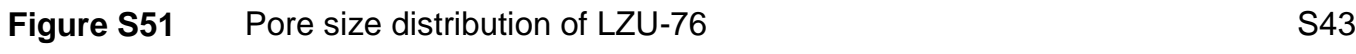

Figure S52 Simulated nitrogen adsorption isotherm of LZU-76 S44

$\begin{array}{lll}\text { Figure S53 Simulated BET surface area plot for LZU-76 } & \text { S44 }\end{array}$

Figure S54 SEM images of LZU-76-Boc and LZU-76 S45

Figure S55 TEM images of LZU-76-Boc and LZU-76 S45

Figure S56 Observed and calculated PXRD patterns of LZU-76 S46

Table S3 Fractional atomic coordinates for the unit cell of LZU-76 S47

Table S4 Optimization of the reaction conditions of asymmetric aldol reaction S48

Table S5 Recycle test of LZU-76

Figure S57 PXRD patterns of fresh and recycled LZU-76 $\quad$ S51

Figure S58 $\quad{ }^{13} \mathrm{C}$ CP/MAS NMR spectra of fresh and recycled LZU-76 S51

Liquid ${ }^{1} \mathrm{H}$ and ${ }^{13} \mathrm{C}$ NMR Spectra $\quad \mathrm{S} 53$

$\begin{array}{ll}\text { HPLC Spectra } & \text { S62 }\end{array}$ 


\section{General Information}

All starting compounds and solvents were purchased from commercial sources and, if necessary, purified before use by standard techniques. Compounds $\mathbf{S} \mathbf{1}$ and $\mathbf{S} 3$ were prepared according to the literature procedures. ${ }^{1}$ All anhydrous reactions were carried out under dry argon by using Schlenk line techniques. Liquid ${ }^{1} \mathrm{H}$ and ${ }^{13} \mathrm{C}$ NMR spectra were recorded on a Bruker Avance III $400 \mathrm{MHz}$ or a Varian Inova $600 \mathrm{MHz}$ NMR spectrometer. High resolution mass spectra (HRMS) were obtained with ESI ionization sources on a Bruker Maxis 4G (Data analysis 4.0) instrument. Powder X-ray diffraction (PXRD) data were collected using a PANalytical X'Pert Pro diffractometer operated at $40 \mathrm{kV}$ and $40 \mathrm{~mA}$ with $\mathrm{Cu} \mathrm{K} \alpha$ radiation (step size of $0.017^{\circ}$ and step time of $8.41 \mathrm{~s}$ ). Elemental analysis was performed on an Elementar Analysensysteme GmbH VarioEL V3.00 elemental analyser. FT-IR spectra were collected on a Nicolet NEXUS 670 instrument. Solid-state NMR experiments were performed on a Bruker WB Avance II $400 \mathrm{MHz}$ spectrometer. The ${ }^{13} \mathrm{C}$ CP/MAS NMR spectra were recorded with a 4-mm double-resonance MAS probe and with a sample spinning rate of $10.0 \mathrm{kHz}$; a contact time of $2 \mathrm{~ms}$ (ramp 100) and pulse delay of $3 \mathrm{~s}$ were applied. The thermal properties of COFs were evaluated using a STA PT1600 Linseis thermogravimetric analysis (TGA) instrument or a Netzsch STA449C TGA instrument within the temperature range of 20 to $800{ }^{\circ} \mathrm{C}$ under a nitrogen atmosphere with a heating rate of $10{ }^{\circ} \mathrm{C} / \mathrm{min}$. The nitrogen adsorption and desorption isotherms were performed at $77 \mathrm{~K}$ with a Micromeritics ASAP 2020M system. Surface areas were calculated using Langmuir and Brunauer-Emmett-Teller (BET) methods, respectively. The pore-size-distribution curves were calculated from nitrogen adsorption isotherms using non-local density functional theory (NLDFT). Scanning electron microscopy (SEM) images were obtained with a JSM-6701F microscope or a Hitachi S-4800 microscope operated at an accelerating voltage of $5.0 \mathrm{kV}$. Transmission electron microscopy (TEM) images were obtained with an FEI TF20 instrument operated at $200 \mathrm{kV}$. The enantiomeric excess (ee) and enantiomeric ratios (e.r.) were determined by HPLC on a Waters 1525 Delta system with Daicel chiral AS-H, AD-H and OD-H columns and with hexane/i-PrOH as the eluent. 


\section{Synthesis of Monomer 2, N-Boc-protected 3, Monomer 3, and DPBIP}

\section{Synthesis of monomer 2}

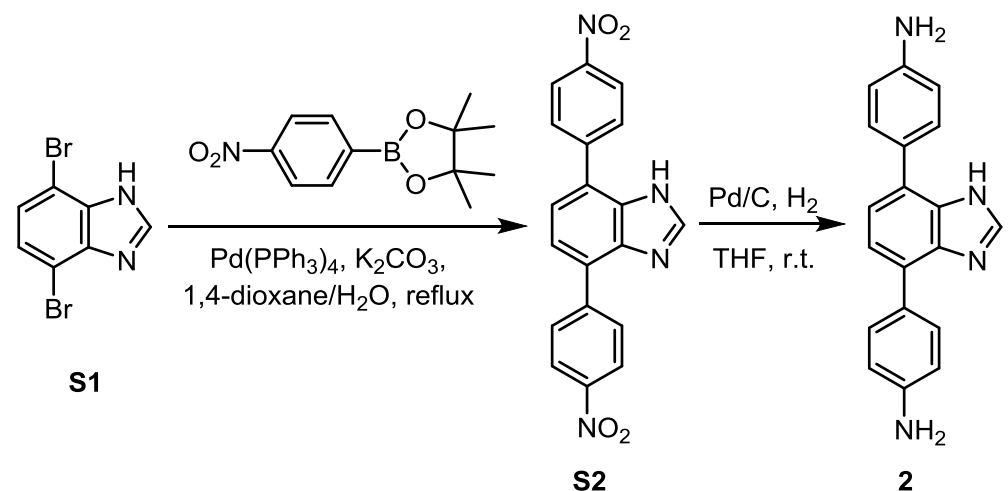

Compound S2. To a two-necked flask were added compound S1 (552 mg, $2.0 \mathrm{mmol}$ ), 4,4,5,5-tetramethyl-2-(4-nitrophenyl)-1,3,2-dioxaborolane (1.10 g, $4.4 \mathrm{mmol}), \mathrm{K}_{2} \mathrm{CO}_{3}(828 \mathrm{mg}, 6.0$ $\mathrm{mmol}$ ), and $\mathrm{Pd}\left(\mathrm{PPh}_{3}\right)_{4}$ (233 mg, $\left.0.2 \mathrm{mmol}\right)$. A degassed mixture of 1,4-dioxane $(16 \mathrm{~mL})$ and $\mathrm{H}_{2} \mathrm{O}(4$ $\mathrm{mL}$ ) was added into the flask under Ar atmosphere. The reaction mixture was heated to reflux at $100{ }^{\circ} \mathrm{C}$ for $8 \mathrm{~h}$. After cooling to room temperature, the mixture was filtered and the solid residue was rinsed with $\mathrm{H}_{2} \mathrm{O}$, EtOAc, and $\mathrm{Et}_{2} \mathrm{O}$. Drying under air gave compound $\mathbf{S 2}$ (649 $\mathrm{mg}, 90 \%$ yield). ${ }^{1} \mathrm{H}$ NMR (400 MHz, DMSO- $\left.d_{6}\right): \delta=8.44(\mathrm{~s}, 1 \mathrm{H}), 8.38-8.35(\mathrm{~m}, 4 \mathrm{H}), 8.26-8.24(\mathrm{~m}, 4 \mathrm{H}), 7.63(\mathrm{~s}, 2 \mathrm{H}) .{ }^{13} \mathrm{C}$ NMR $\left(100 \mathrm{MHz}\right.$, DMSO- $\left.d_{6}\right): \delta=146.6,144.2,144.1,129.7,123.8,122.4$. HRMS: $\mathrm{m} / \mathrm{z}$ calcd for $\mathrm{C}_{19} \mathrm{H}_{12} \mathrm{~N}_{4} \mathrm{O}_{4}[\mathrm{M}+\mathrm{H}]^{+}: 361.0931$, found: 361.0929 .

Monomer 2 (4,4'-(1H-benzo[d]imidazole-4,7-diyl)dianiline). Compound S2 (360 mg, $1.0 \mathrm{mmol})$ was dissolved in dry THF $(20 \mathrm{~mL})$ at room temperature. To the mixture was added $10 \% \mathrm{Pd} / \mathrm{C}(100$ $\mathrm{mg}$ ). The mixture was then degassed, backfilled with $\mathrm{H}_{2}$ five times, and stirred under $\mathrm{H}_{2}$ atmosphere at room temperature for $24 \mathrm{~h}$. After the reaction was completed, the reaction mixture was filtered through Celite to afford a clear solution. The solution was then evaporated under reduced pressure to give monomer 2 (276 mg, 92\% yield). ${ }^{1} \mathrm{H}$ NMR (400 MHz, DMSO- $\left.d_{6}\right): \delta=12.32(\mathrm{~s}, 1 \mathrm{H}), 8.15(\mathrm{~s}$, $1 \mathrm{H}), 7.88(\mathrm{~d}, J=6.8 \mathrm{~Hz}, 2 \mathrm{H}), 7.35-7.32(\mathrm{~m}, 3 \mathrm{H}), 7.18-7.16(\mathrm{~m}, 1 \mathrm{H})$, 6.73-6.66 $(\mathrm{m}, 4 \mathrm{H})$, 5.27-5.18 (m, $4 \mathrm{H}) .{ }^{13} \mathrm{C}$ NMR $\left(150 \mathrm{MHz}\right.$, DMSO- $\left.d_{6}\right): \delta=148.2,147.8,141.7,140.7,131.3,129.3,128.5,125.9$, 125.4, 124.1, 121.3, 119.2, 114.3, 113.6. HRMS: $\mathrm{m} / \mathrm{z}$ calcd for $\mathrm{C}_{19} \mathrm{H}_{16} \mathrm{~N}_{4}[\mathrm{M}+\mathrm{H}]^{+}: 301.1448$, found: 301.1445 . 


\section{Synthesis of N-Boc-protected 3}

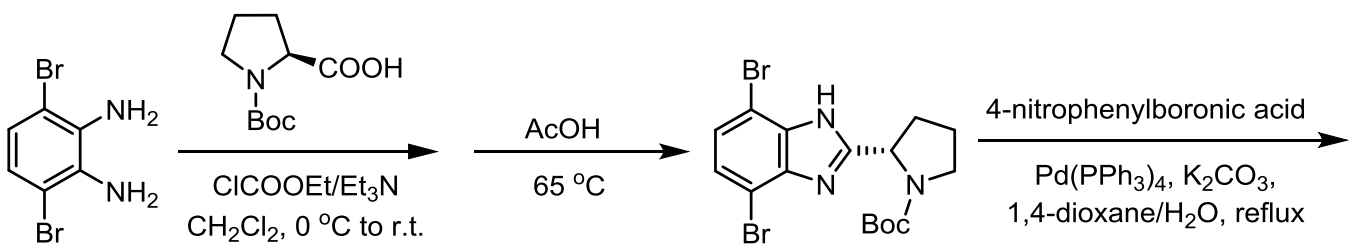

S3<smiles>CC(C)(C)OC(=O)N1CCC[C@H]1c1nc2c(-c3ccc([N+](=O)[O-])cc3)ccc(-c3ccc([N+](=O)[O-])cc3)c2[nH]1</smiles>

S5
S4

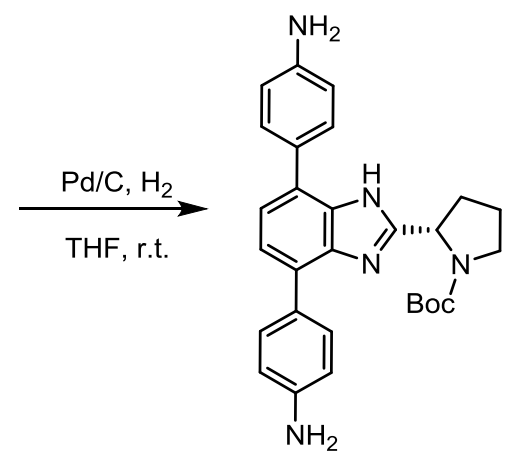

N-Boc-protected 3

Compound S4. ${ }^{2}$ Boc-protected $L$-proline $(5.17 \mathrm{~g}, 24.0 \mathrm{mmol})$ was dissolved in anhydrous $\mathrm{CH}_{2} \mathrm{Cl}_{2}$ $(60 \mathrm{~mL})$ at $0{ }^{\circ} \mathrm{C}$. To the mixture were added ethyl chloroformate $(2.28 \mathrm{~mL}, 24.0 \mathrm{mmol})$ and $\mathrm{Et}_{3} \mathrm{~N}$ (6.65 $\mathrm{mL}, 48.0 \mathrm{mmol})$ dropwise. Compound $\mathbf{S 3}(5.32 \mathrm{~g}, 20.0 \mathrm{mmol})$ was then added, and the resulting mixture was stirred at room temperature for $36 \mathrm{~h}$. The residue was treated with $\mathrm{H}_{2} \mathrm{O}(100$ $\mathrm{mL})$, extracted with $\mathrm{CH}_{2} \mathrm{Cl}_{2}(3 \times 40 \mathrm{~mL})$, and the combined organic phase was then dried over anhydrous $\mathrm{Na}_{2} \mathrm{SO}_{4}$. After removing the solvent under reduced pressure, a light brown oil was obtained. The oil was dissolved in glacial acetic acid $(25 \mathrm{~mL})$ and the reaction mixture was heated at $65^{\circ} \mathrm{C}$ for $12 \mathrm{~h}$. After cooling to room temperature, the residue was treated with saturated $\mathrm{Na}_{2} \mathrm{CO}_{3}$ solution to an approximate $\mathrm{pH}$ of 8.0 . The mixture was then extracted with EtOAc $(3 \times 40 \mathrm{~mL})$. The organic layer was collected, washed with brine, dried over $\mathrm{Na}_{2} \mathrm{SO}_{4}$, and concentrated under reduced pressure. The crude product was purified by silica gel column chromatography using petroleum ether/EtOAc $=8 / 1$ as the eluent to give the product $\mathbf{S 4}(3.91 \mathrm{~g}, 44 \%$ yield $)$ as a pale yellow solid. ${ }^{1} \mathrm{H}$ NMR (400 MHz, $\left.\mathrm{CDCl}_{3}\right): \delta=11.17(\mathrm{~s}, 1 \mathrm{H}), 7.18(\mathrm{~d}, J=36.0 \mathrm{~Hz}, 2 \mathrm{H}), 5.14-5.13(\mathrm{~m}$, $1 \mathrm{H}), 3.56-3.44(\mathrm{~m}, 2 \mathrm{H}), 2.98(\mathrm{~m}, 1 \mathrm{H}), 2.61-2.18(\mathrm{~m}, 2 \mathrm{H}), 2.00-1.95(\mathrm{~m}, 1 \mathrm{H}), 1.49(\mathrm{~s}, 9 \mathrm{H}) .{ }^{13} \mathrm{C} N M R$ $\left(100 \mathrm{MHz}, \mathrm{CDCl}_{3}\right): \delta=156.5,156.1,141.3,134.2,125.7,112.0,102.3,80.9,54.7,47.3,28.5,28.3$, 24.7. HRMS: $m / z$ calcd for $\mathrm{C}_{16} \mathrm{H}_{20} \mathrm{Br}_{2} \mathrm{~N}_{3} \mathrm{O}_{2}[\mathrm{M}+\mathrm{H}]^{+}:$:43.9916, found: 443.9908 .

Compound S5. 4-Nitrobenzeneboronic acid (768 mg, $4.6 \mathrm{mmol}$ ), compound S4 (886 mg, 2.0 $\mathrm{mmol}), \mathrm{K}_{2} \mathrm{CO}_{3}(828 \mathrm{mg}, 6.0 \mathrm{mmol})$, and $\mathrm{Pd}\left(\mathrm{PPh}_{3}\right)_{4}(233 \mathrm{mg}, 0.2 \mathrm{mmol})$ were added into a two-necked flask. A degassed mixture of 1,4-dioxane $(16 \mathrm{~mL})$ and $\mathrm{H}_{2} \mathrm{O}(4 \mathrm{~mL})$ was added into the flask under $\mathrm{Ar}$ atmosphere. The reaction mixture was heated to reflux at $100{ }^{\circ} \mathrm{C}$ for $8 \mathrm{~h}$. After cooling to room temperature, the solvent was evaporated under reduced pressure and the residue was diluted with $\mathrm{H}_{2} \mathrm{O}(50 \mathrm{~mL})$, extracted with $\mathrm{CH}_{2} \mathrm{Cl}_{2}(3 \times 30 \mathrm{~mL})$. The combined organic layer was washed with brine, dried over $\mathrm{Na}_{2} \mathrm{SO}_{4}$, and then evaporated to dryness. The crude product was purified by flash column chromatography on silica gel using $\mathrm{CH}_{2} \mathrm{Cl}_{2}$ as the eluent to give the product S5 (760 mg, 72\% yield) as a yellow solid. ${ }^{1} \mathrm{H}$ NMR $\left(400 \mathrm{MHz}, \mathrm{CDCl}_{3}\right): \delta=11.54(\mathrm{~s}, 1 \mathrm{H}), 8.36-8.33$ (m, 6H), 7.79 (d, J = 8.8 Hz, 2H), 7.59 (d, J = 7.6 Hz, 1H), 7.45 (d, J = 7.6 Hz, 1H), 5.19-5.17 (m, 
$1 \mathrm{H}), 3.50-3.48(\mathrm{~m}, 2 \mathrm{H}), 3.12-3.10(\mathrm{~m}, 1 \mathrm{H}), 2.28-2.16(\mathrm{~m}, 2 \mathrm{H}), 2.08-2.05(\mathrm{~m}, 1 \mathrm{H}), 1.53(\mathrm{~s}, 9 \mathrm{H}) .{ }^{13} \mathrm{C}$ $\operatorname{NMR}\left(100 \mathrm{MHz}, \mathrm{CDCl}_{3}\right): \delta=156.9,156.6,147.1,146.9,144.6,140.8,133.0,129.8,128.3,124.5$, 123.6, 122.8, 122.0, 81.1, 54.8, 47.5, 28.3, 27.9, 24.8. HRMS: $\mathrm{m} / \mathrm{z}$ calcd for $\mathrm{C}_{28} \mathrm{H}_{28} \mathrm{~N}_{5} \mathrm{O}_{6}[\mathrm{M}+\mathrm{H}]^{+}$: 530.2034, found: 530.2046 . The enantiomeric excess (> 99\% ee) was determined by HPLC with Daicel chiral AD-H column at $254 \mathrm{~nm}$ (hexane $/ i-\mathrm{PrOH}=90 / 10$, flow rate $1.0 \mathrm{~mL} / \mathrm{min}$ ), $\mathrm{t}$ (major) $=$ $15.2 \mathrm{~min}, \mathrm{t}$ (minor) $=22.5 \mathrm{~min}$.

\section{N-Boc-protected 3 (tert-butyl (S)-2-(4,7-bis(4-aminophenyl)-1 H-benzo[d]imidazol-2-yl)pyrrol-}

idine-1-carboxylate). Compound $\mathbf{S} 5(529 \mathrm{mg}, 1.0 \mathrm{mmol})$ was dissolved in dry THF $(40 \mathrm{~mL})$ at room temperature. To the mixture was added $5 \% \mathrm{Pd} / \mathrm{C}(200 \mathrm{mg})$. The mixture was then degassed, backfilled with $\mathrm{H}_{2}$ five times, and stirred under $\mathrm{H}_{2}$ atmosphere at $30{ }^{\circ} \mathrm{C}$ for $4 \mathrm{~h}$. After the reaction was completed, the reaction mixture was filtered through Celite to afford a clear solution. The solution was then evaporated under reduced pressure to give $\mathrm{N}$-Boc-protected 3 (422 $\mathrm{mg}, 90 \%$ yield) as a white powder. ${ }^{1} \mathrm{H}$ NMR $\left(400 \mathrm{MHz}\right.$, DMSO- $\left.d_{6}\right): \delta=11.93(\mathrm{~d}, J=21.6 \mathrm{~Hz}, 1 \mathrm{H}), 7.85(\mathrm{~d}, J=$ $7.6 \mathrm{~Hz}, 2 \mathrm{H}), 7.31-7.25(\mathrm{~m}, 3 \mathrm{H}), 7.11-7.06(\mathrm{~m}, 1 \mathrm{H}), 6.71(\mathrm{~d}, J=8.0 \mathrm{~Hz}, 2 \mathrm{H}), 6.33(\mathrm{~d}, J=8.4 \mathrm{~Hz}, 2 \mathrm{H})$, 5.26-5.12 (m, 4H), 5.08-5.00 (m, 1H), 3.60-3.58 (m, 1H), 3.41-3.39 (m, 1H), 2.24-2.23 (m, $1 \mathrm{H})$, 2.08-2.00 (m, 2H), 1.88-1.87 (m, 1H), $1.42(\mathrm{~s}, 5 \mathrm{H}), 1.10(\mathrm{~s}, 4 \mathrm{H}) .{ }^{13} \mathrm{C}$ NMR $\left(150 \mathrm{MHz}\right.$, DMSO- $\left.d_{6}\right): \delta=$ 156.7, 155.9, 153.9, 153.4, 148.2, 148.1, 147.7, 147.6, 140.7, 140.4, 132.1, 132.0, 129.3, 129.2, 128.7, 128.6, 128.5, 128.5, 126.1, 126.0, 125.6, 125.5, 123.7, 123.6, 121.0, 120.9, 119.0, 118.9, 114.2, 113.6, 78.6, 78.1, 55.2, 54.7, 48.3, 46.6, 46.4, 33.1, 31.5, 28.1, 27.8, 23.7, 23.1. HRMS: m/z calcd for $\mathrm{C}_{28} \mathrm{H}_{32} \mathrm{~N}_{5} \mathrm{O}_{2}[\mathrm{M}+\mathrm{H}]^{+}: 470.2551$, found: 470.2565 . The enantiomeric excess (99\% ee) was determined by HPLC with Daicel chiral AD-H column at $322 \mathrm{~nm}$ (hexane $/ i-\mathrm{PrOH}=70 / 30$, flow rate $1.0 \mathrm{~mL} / \mathrm{min}), \mathrm{t}$ (major) $=60.7 \mathrm{~min}, \mathrm{t}($ minor $)=17.1 \mathrm{~min}$. 


\section{Synthesis of monomer 3}<smiles>CC(C)(C)OC(=O)N1CCC[C@H]1c1nc2c(-c3ccc(N)cc3)ccc(-c3ccc(N)cc3)c2[nH]1</smiles>

N-Boc-protected 3<smiles>Nc1ccc(-c2ccc(-c3ccc(N)cc3)c3[nH]c([C@@H]4CCCN4)nc23)cc1</smiles>

3

Monomer 3 ((S)-4,4'-(2-(pyrrolidin-2-yl)-1 H-benzo[d]imidazole-4,7-diyl)dianiline). N-Boc-protected $3(235 \mathrm{mg}, 0.5 \mathrm{mmol})$ was added into $4 \mathrm{M} \mathrm{HCl} / 1,4$-dioxane $(3 \mathrm{~mL})$. The mixture was stirred at room temperature for $2 \mathrm{~h}$, and then passed through a filter to get the hydrochloride, which was subsequently neutralized with $1 \mathrm{M} \mathrm{NaOH}$ solution. Then, the mixture was extracted with $\mathrm{CH}_{2} \mathrm{Cl}_{2}(3 \times$ $40 \mathrm{~mL}$ ). The organic layer was washed with brine, dried over $\mathrm{Na}_{2} \mathrm{SO}_{4}$, and concentrated under reduced pressure to give monomer 3 (129 mg, 70\% yield) as an orange solid. ${ }^{1} \mathrm{H} \mathrm{NMR}(400 \mathrm{MHz}$, $\left.\mathrm{CDCl}_{3}\right) \delta=7.67(\mathrm{~d}, J=4.8 \mathrm{~Hz}, 4 \mathrm{H}), 7.31(\mathrm{~s}, 2 \mathrm{H}), 6.82(\mathrm{~d}, J=8.5 \mathrm{~Hz}, 4 \mathrm{H}), 4.58-4.55(\mathrm{~m}, 1 \mathrm{H}), 3.74$ (brs, $4 \mathrm{H}), 3.04(\mathrm{t}, J=6.8 \mathrm{~Hz}, 2 \mathrm{H}), 2.35-2.26(\mathrm{~m}, 1 \mathrm{H}), 2.16-2.10(\mathrm{~m}, 1 \mathrm{H}), 1.85-1.79(\mathrm{~m}, 2 \mathrm{H}) .{ }^{13} \mathrm{C} \mathrm{NMR}$ $\left(100 \mathrm{MHz}, \mathrm{CDCl}_{3}\right) \delta=158.0,145.7,129.5,129.2,121.3,115.4,56.4,47.1,32.8,25.7 . \mathrm{HRMS}: \mathrm{m} / \mathrm{z}$ calcd for $\mathrm{C}_{23} \mathrm{H}_{24} \mathrm{~N}_{5}[\mathrm{M}+\mathrm{H}]^{+}$: 370.2026, found: 370.2037.

\section{Synthesis of DPBIP}

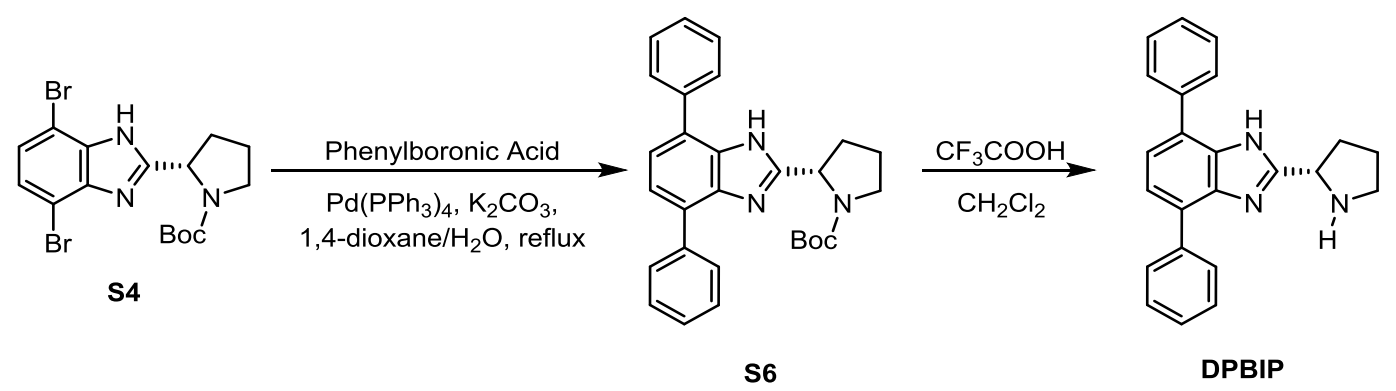

Compound S6. Phenylboronic acid ( $280 \mathrm{mg}, 2.3 \mathrm{mmol}$ ), compound S4 (443 mg, $1.0 \mathrm{mmol}$ ), $\mathrm{K}_{2} \mathrm{CO}_{3}$ (414 mg, $3.0 \mathrm{mmol})$, and $\mathrm{Pd}\left(\mathrm{PPh}_{3}\right)_{4}(117 \mathrm{mg}, 0.1 \mathrm{mmol})$ were added into a two-necked flask. $\mathrm{A}$ degassed mixture of 1,4-dioxane $(8 \mathrm{~mL})$ and $\mathrm{H}_{2} \mathrm{O}(2 \mathrm{~mL})$ was added into the flask under $\mathrm{Ar}$ atmosphere. The reaction mixture was heated to reflux at $100^{\circ} \mathrm{C}$ for $6 \mathrm{~h}$. After cooling to room temperature, the solvent was evaporated under reduced pressure and the residue was diluted with $\mathrm{H}_{2} \mathrm{O}(25 \mathrm{~mL})$, extracted with $\mathrm{CH}_{2} \mathrm{Cl}_{2}(3 \times 15 \mathrm{~mL})$. The combined organic layer was washed with brine, dried over $\mathrm{Na}_{2} \mathrm{SO}_{4}$, and then evaporated to dryness. The crude product was purified by flash column chromatography on silica gel using $\mathrm{CH}_{2} \mathrm{Cl}_{2}$ as the eluent to give the product $\mathbf{S 6}$ (413 $\mathrm{mg}$, $94 \%$ yield) as an off-white solid. ${ }^{1} \mathrm{H}$ NMR $\left(400 \mathrm{MHz}, \mathrm{CDCl}_{3}\right) \delta=11.18(\mathrm{~s}, 1 \mathrm{H}), 8.20(\mathrm{~d}, J=7.2 \mathrm{~Hz}$, 2H), $7.71(\mathrm{~d}, J=7.2 \mathrm{~Hz}, 2 \mathrm{H}), 7.56-7.52(\mathrm{~m}, 5 \mathrm{H}), 7.44-7.41(\mathrm{~m}, 3 \mathrm{H})$, 5.19-5.17 (m, 1H), 3.47-3.45 (m, $2 \mathrm{H}), 3.23(\mathrm{~m}, 1 \mathrm{H}), 2.21-2.20(\mathrm{~m}, 2 \mathrm{H}), 2.04(\mathrm{~m}, 1 \mathrm{H}), 1.57(\mathrm{~s}, 9 \mathrm{H}) .{ }^{13} \mathrm{C} \mathrm{NMR}\left(100 \mathrm{MHz}, \mathrm{CDCl}_{3}\right) \delta=$ 156.6, 155.3, 140.3, 138.4, 133.1, 131.0, 129.2, 129.1, 128.3, 127.6, 127.4, 127.1, 124.5, 122.3, 
121.5, 80.6, 54.9, 47.3, 28.4, 27.9, 24.8. HRMS: $\mathrm{m} / \mathrm{z}$ calcd for $\mathrm{C}_{28} \mathrm{H}_{30} \mathrm{~N}_{3} \mathrm{O}_{2}[\mathrm{M}+\mathrm{H}]^{+}: 440.2333$, found: 440.2321 .

Compound DPBIP ((S)-4,7-diphenyl-2-(pyrrolidin-2-yl)-1H-benzo[d] imidazole). Compound S6 (220 mg, $0.5 \mathrm{mmol}$ ) was suspended in $\mathrm{CH}_{2} \mathrm{Cl}_{2}(3.7 \mathrm{~mL})$ and the mixture was cooled to $0{ }^{\circ} \mathrm{C}$ with stirring. Next, trifluoroacetic acid (TFA) $(3.7 \mathrm{~mL})$ was added and stirring was continued for $10 \mathrm{~min}$. The mixture was then allowed to warm to room temperature and stirred for $3 \mathrm{~h}$. The solvent was removed under reduced pressure, and the residue was cooled in an ice bath with stirring and then dissolved in $1 \mathrm{M} \mathrm{KOH}$. The mixture was extracted with $\mathrm{CH}_{2} \mathrm{Cl}_{2}(3 \times 20 \mathrm{~mL})$. The organic layer was washed with brine, dried over $\mathrm{Na}_{2} \mathrm{SO}_{4}$, and concentrated under reduced pressure to give DPBIP (156 mg, $92 \%$ yield) as a pale yellow solid. ${ }^{1} \mathrm{H} \mathrm{NMR}\left(400 \mathrm{MHz}, \mathrm{CDCl}_{3}\right) \delta=7.87(\mathrm{~d}, J=6.8 \mathrm{~Hz}, 4 \mathrm{H})$, 7.55-7.52 (m, 4H), 7.42-7.39 (m, 4H), 4.58-4.54 (m, 1H), 3.02-2.99 (m, $2 \mathrm{H})$, 2.35-2.26 (m, $1 \mathrm{H})$, 2.16-2.08 (m, 1H), 1.82-1.81 (m, 2H). ${ }^{13} \mathrm{C} \mathrm{NMR}\left(100 \mathrm{MHz}, \mathrm{CDCl}_{3}\right) \delta=158.3,138.6,128.8,128.5$, 127.3, 122.1, 56.2, 46.9, 32.6, 25.6. HRMS: $\mathrm{m} / \mathrm{z}$ calcd for $\mathrm{C}_{23} \mathrm{H}_{22} \mathrm{~N}_{3}[\mathrm{M}+\mathrm{H}]^{+}: 340.1808$, found: 340.1799 .

\section{Conversion of DPBIP under Solvothermal Conditions}<smiles>c1ccc(-c2ccc(-c3ccccc3)c3[nH]c([C@H]4CCCN4)nc23)cc1</smiles>

DPBIP

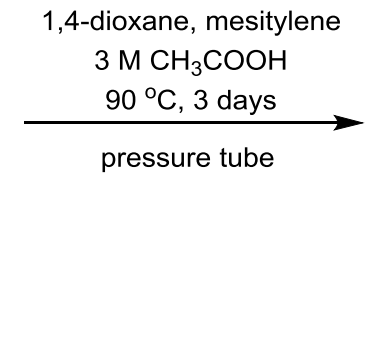

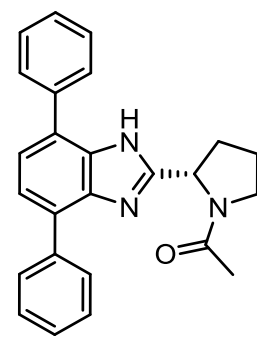

6

To a $10 \mathrm{~mL}$ pressure tube were added DPBIP $(25.4 \mathrm{mg}, 0.075 \mathrm{mmol})$, 1,4-dioxane $(0.5 \mathrm{~mL})$, mesitylene $(0.5 \mathrm{~mL})$, and $3 \mathrm{M}$ acetic acid $(0.2 \mathrm{~mL})$. The tube was temporally sealed with a rubber plug and subsequently was flushed three times in argon/vacuum cycles. The tube was sealed and placed in an oven at $90^{\circ} \mathrm{C}$ and left undisturbed for 3 days, yielding a clear solution. After cooling to room temperature, the solvent was evaporated under reduced pressure to give the crude product. The crude product was purified by flash column chromatography on silica gel using $\mathrm{CH}_{2} \mathrm{Cl}_{2} / \mathrm{EtOAc}=$ $30 / 1$ as the eluent to afford 6 ((S)-1-(2-(4,7-diphenyl-1 $H$-benzo[d]imidazol-2-yl)pyrrolidin-1-yl)ethan1-one) (13.2 mg, $46 \%$ yield). ${ }^{1} \mathrm{H}$ NMR $\left(400 \mathrm{MHz}, \mathrm{CDCl}_{3}\right) \delta=10.99(\mathrm{~s}, 1 \mathrm{H}), 8.17(\mathrm{~d}, J=7.6 \mathrm{~Hz}, 2 \mathrm{H})$, $7.69(\mathrm{~d}, J=7.6 \mathrm{~Hz}, 2 \mathrm{H}), 7.58-7.49(\mathrm{~m}, 5 \mathrm{H}), 7.43-7.40(\mathrm{~m}, 3 \mathrm{H}), 5.41-5.39(\mathrm{~m}, 1 \mathrm{H})$, 3.57-3.53 (m, $2 \mathrm{H})$, 3.27-3.22 (m, 1H), 2.47-2.39 (m, 1H), 2.22-2.13 (m, 2H), $2.11(\mathrm{~s}, 3 \mathrm{H}) .{ }^{13} \mathrm{C} \mathrm{NMR}\left(100 \mathrm{MHz}, \mathrm{CDCl}_{3}\right) \delta$ $=171.4,154.2,140.3,138.5,131.0,129.3,128.2,127.6,127.1,124.7,122.6,121.6,54.8,48.6$, 27.7, 25.4, 22.6. HRMS: $\mathrm{m} / \mathrm{z}$ calcd for $\mathrm{C}_{25} \mathrm{H}_{24} \mathrm{~N}_{3} \mathrm{O}[\mathrm{M}+\mathrm{H}]^{+}$: 382.1914, found: 382.1903 . 


\section{Synthesis, Characterization, and Structural Modeling of LZU-70}

\section{Synthesis of LZU-70}

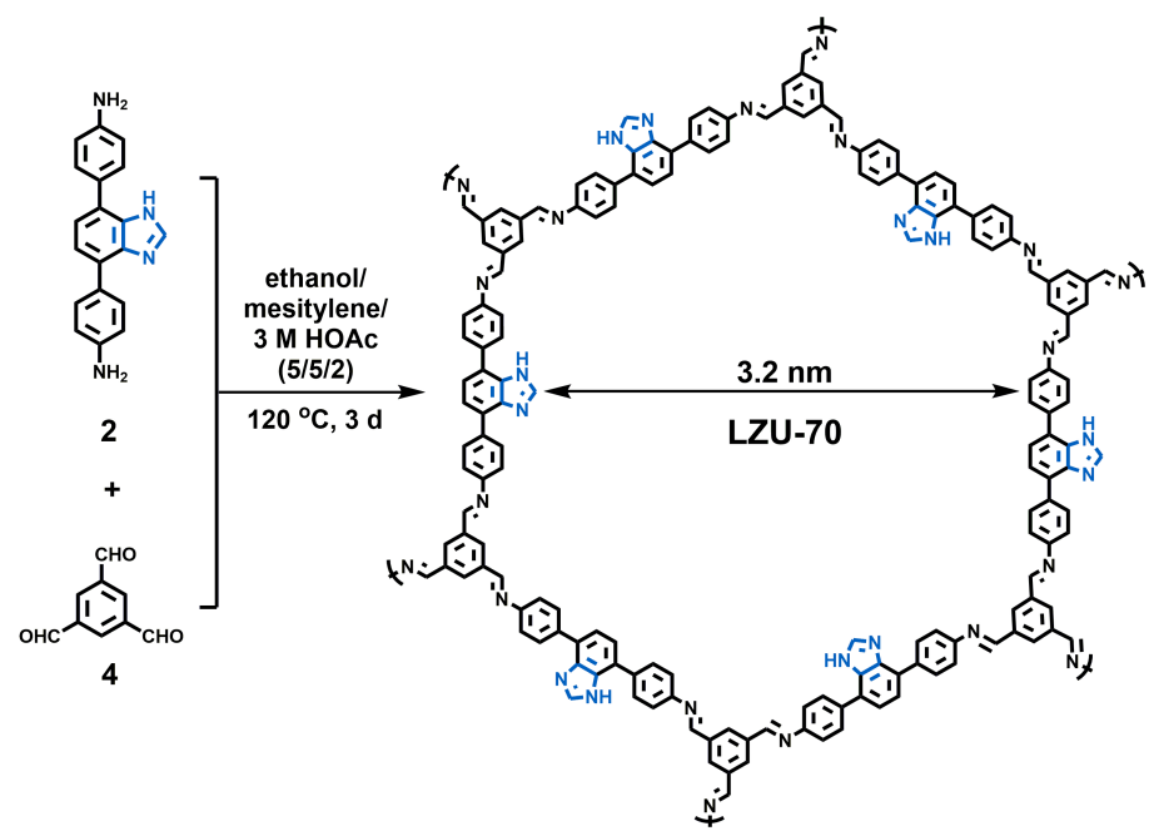

Scheme S1. Synthesis of LZU-70 by condensation of monomer 2 and monomer 4.

LZU-70. 1,3,5-Triformylbenzene (4) (8.1 mg, $0.050 \mathrm{mmol})$ and monomer $2(22.5 \mathrm{mg}, 0.075 \mathrm{mmol})$ were weighed into a $10 \mathrm{~mL}$ pressure ampoule (body length of $18 \mathrm{~cm}$ and neck length of $9 \mathrm{~cm}$ ). To the mixture were added ethanol $(0.5 \mathrm{~mL})$, mesitylene $(0.5 \mathrm{~mL})$, and $3 \mathrm{M}$ aqueous acetic acid $(0.2 \mathrm{~mL})$. Then the ampoule was flash frozen in a liquid nitrogen bath, evacuated to an internal pressure of 0 mbar and flame sealed, reducing the total length by $c a .10 \mathrm{~cm}$. After warming to room temperature, the sealed ampoule was placed in an oven at $120^{\circ} \mathrm{C}$ and left undisturbed for 3 days, yielding a yellow solid. The ampoule was opened when the mixture was still warm ( $\mathrm{ca} .40^{\circ} \mathrm{C}$ ) and the solid was transferred into a vial, separated by centrifugation, washed with THF $(3 \times 6 \mathrm{~mL})$ and acetone $(3 \times 6 \mathrm{~mL})$. The resulting solid was dried under room temperature, and then at $100{ }^{\circ} \mathrm{C}$ for $12 \mathrm{~h}$ to yield LZU-70 as a yellow powder ( $19.8 \mathrm{mg}, 71 \%$ yield). Further purification of LZU-70 was carried out by Soxhlet extraction in THF for 24 h. Anal. Cald for $\left(\mathrm{C}_{25} \mathrm{H}_{16} \mathrm{~N}_{4}\right)_{n}$ : C 80.65; H 4.30; N 15.05. Found: C 77.19; H 4.43; N 12.31 .

The molecular connectivity, crystallinity, thermal stability, porosity, and morphology of LZU-70 were characterized in details, and the results are shown in the following. 


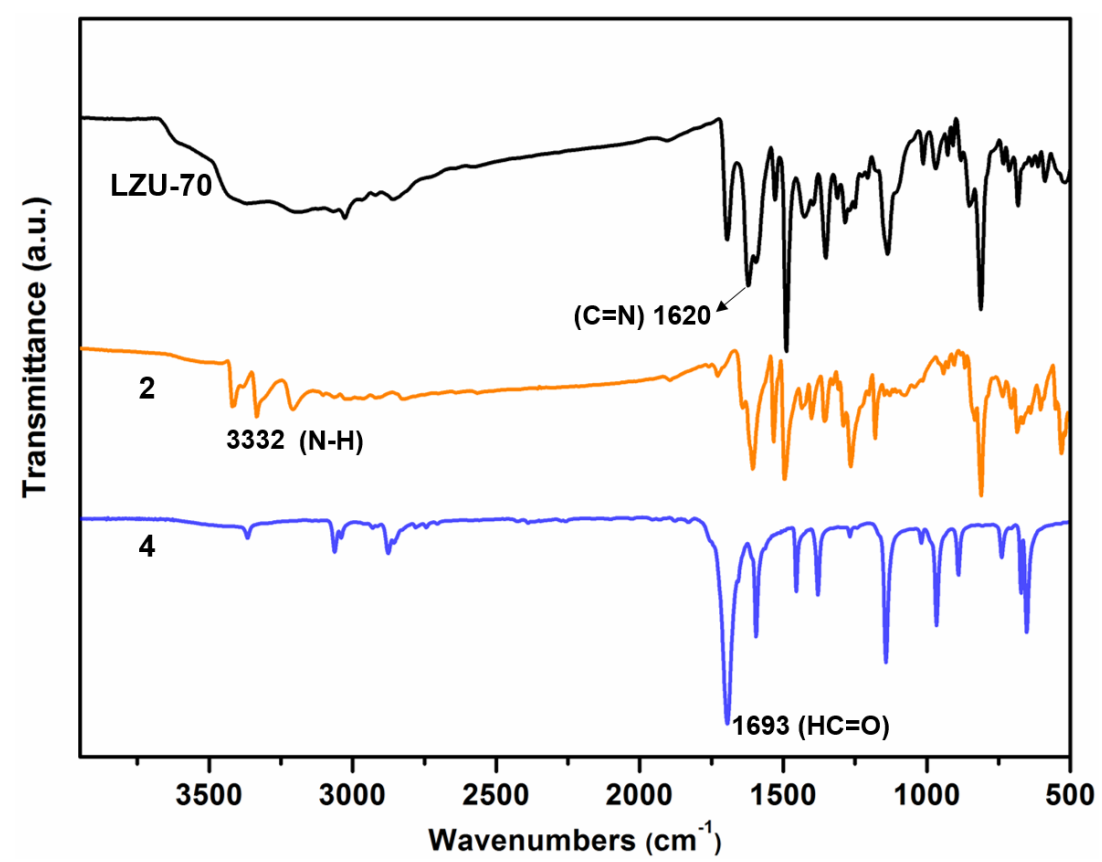

Figure S1. FT-IR spectra of LZU-70 (black), monomer 2 (orange), and monomer 4 (blue). The FT-IR spectrum of LZU-70 (black) shows a $-\mathrm{C}=\mathrm{N}-$ stretch at $1620 \mathrm{~cm}^{-1}$, indicating the successful formation of imine bonds.

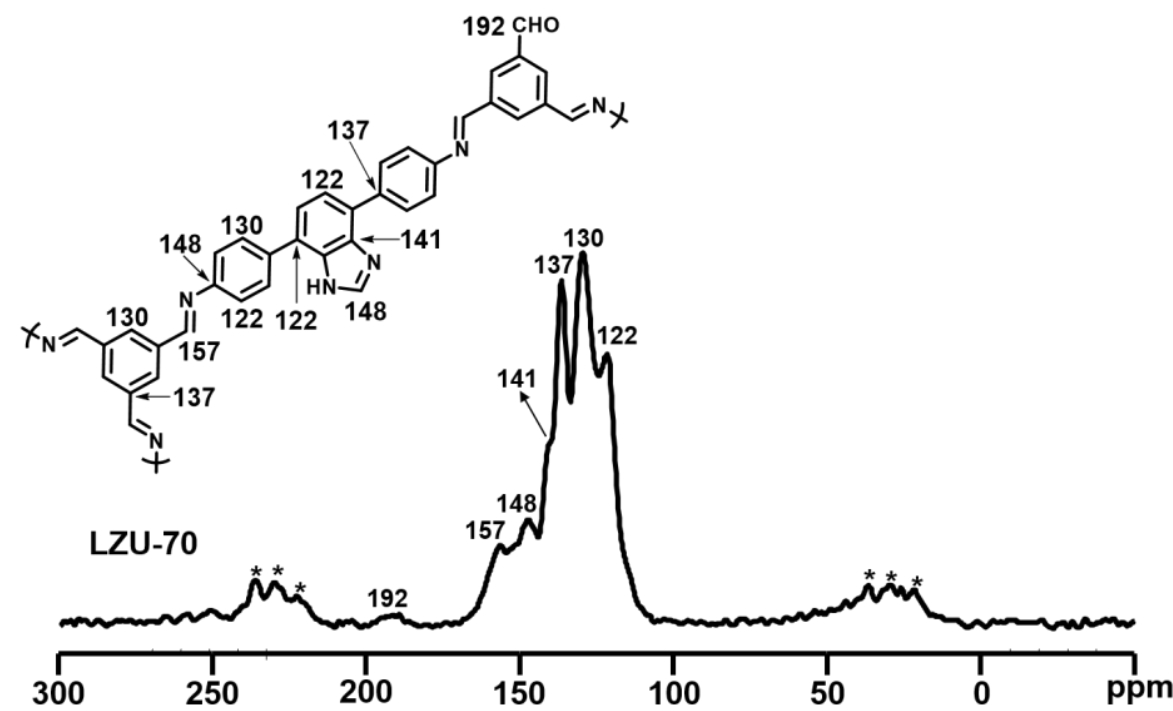

Figure S2. ${ }^{13} \mathrm{C}$ CP/MAS NMR spectrum of LZU-70. The asterisks denote the spinning sidebands. The assignments of ${ }^{13} \mathrm{C}$ chemical shifts of LZU-70 were indicated in the chemical structure. 


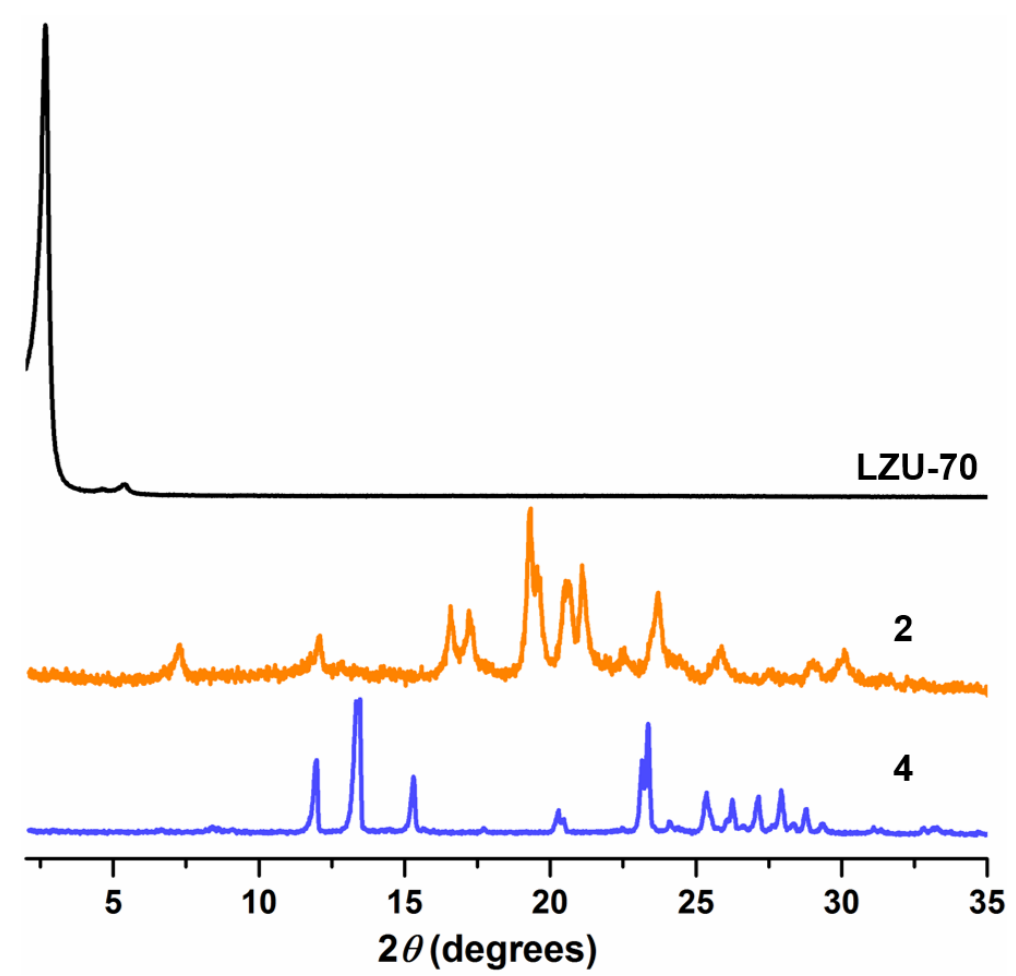

Figure S3. PXRD patterns of LZU-70 (black), monomer 2 (orange), and monomer 4 (blue). No diffraction peaks from the starting material $\mathbf{2}$ or $\mathbf{4}$ could be observed in the PXRD pattern of LZU-70 (black), indicating the sole formation of the crystalline LZU-70 material.

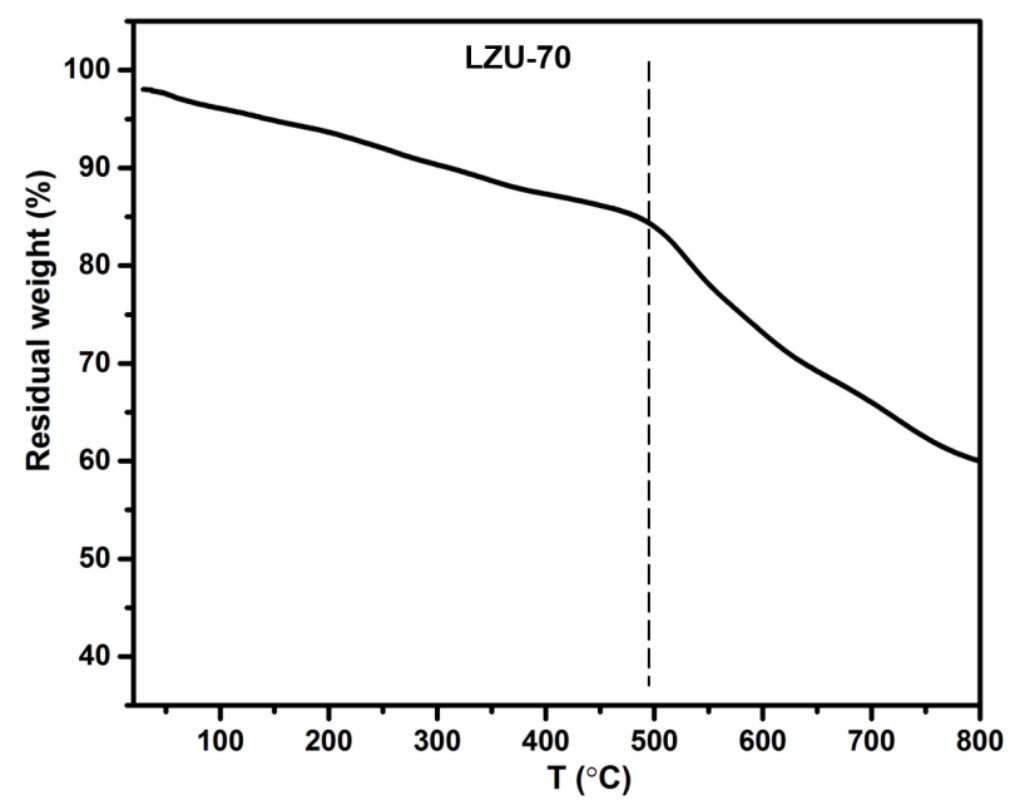

Figure S4. TGA data of LZU-70. LZU-70 is thermally stable up to $490^{\circ} \mathrm{C}$. 


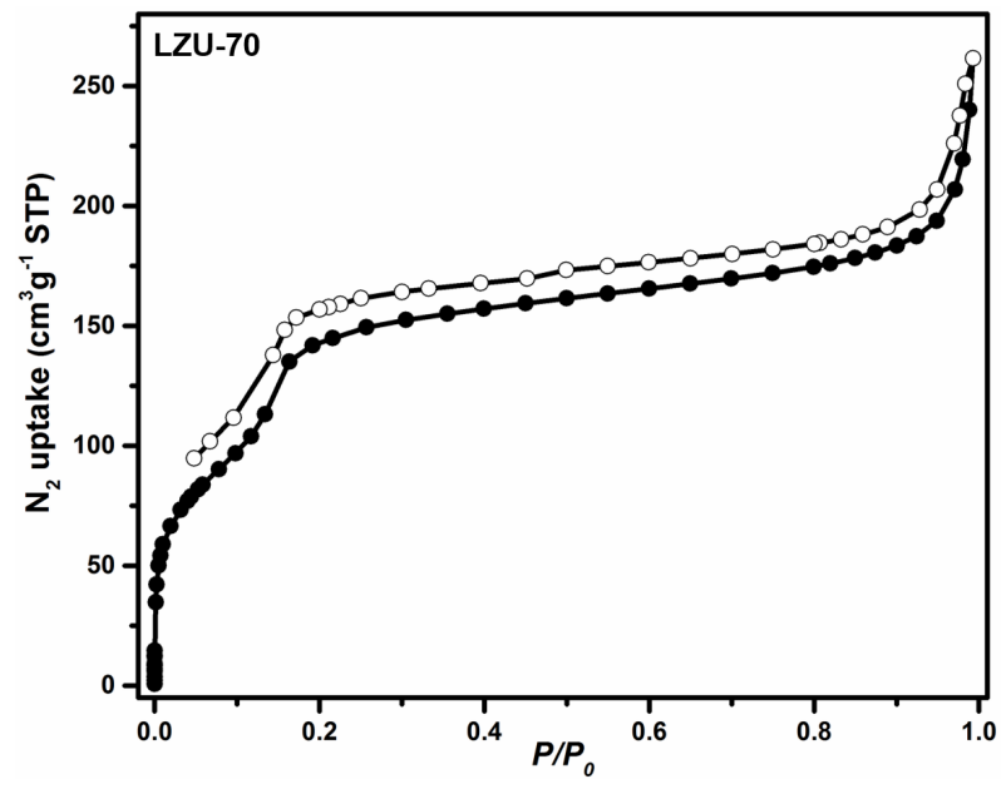

Figure S5. Nitrogen adsorption (filled symbols) and desorption (empty symbols) isotherms of LZU-70. The profile showed a type-IV isotherm, which is characteristic for a mesoporous material.

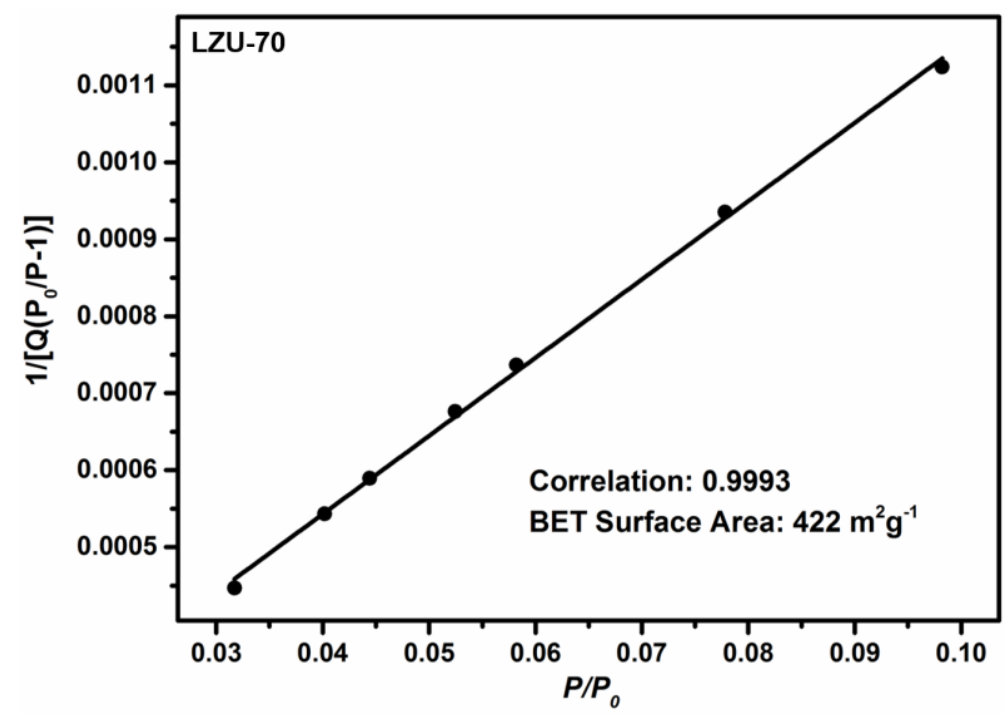

Figure S6. BET surface area plot for LZU-70 calculated from the absorption isotherm. 


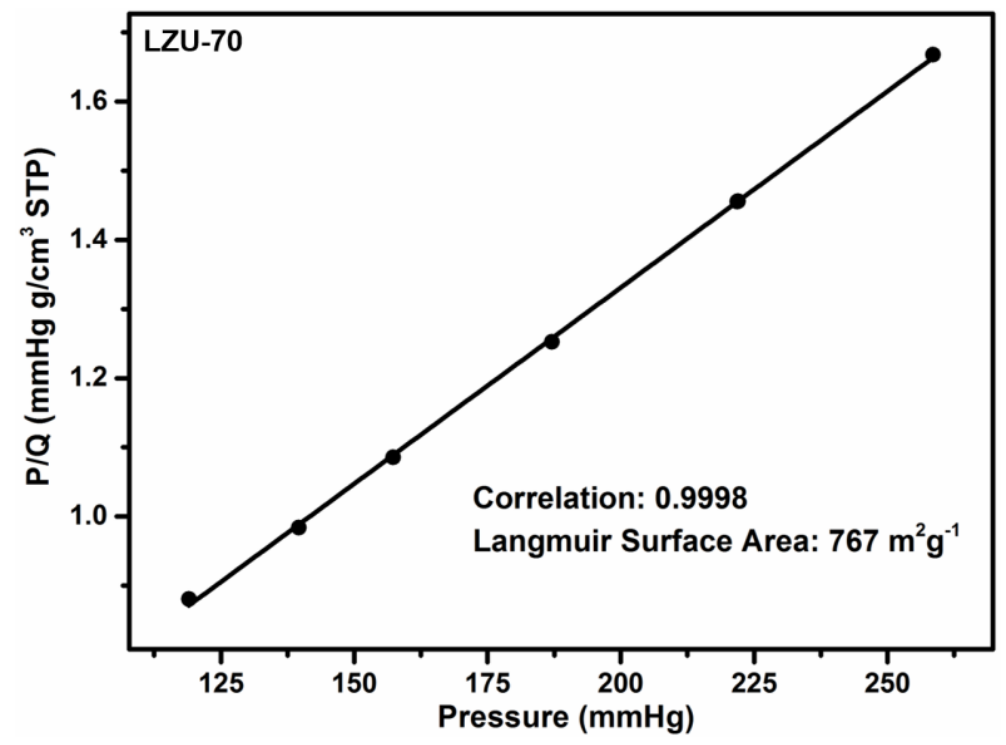

Figure S7. Langmuir surface area plot for LZU-70 calculated from the absorption isotherm.

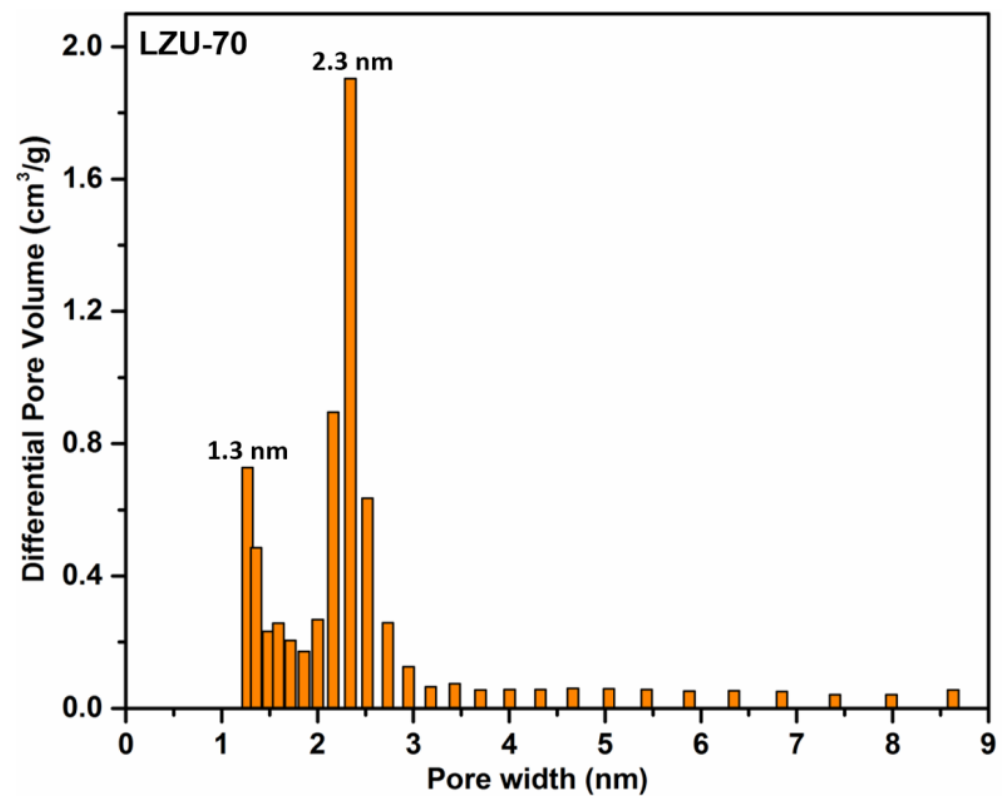

Figure S8. Pore size distribution of LZU-70 calculated by NLDFT (slit pores model). 
Simulations of the nitrogen adsorption isotherm were performed using the Sorption Module in Materials Studio (ver. 7.0) ${ }^{3}$ through Metropolis Monte Carlo method. ${ }^{4}$ Eighty fugacity steps in logarithmic scale $\left(10^{-5}\right.$ to $\left.100 \mathrm{kPa}\right)$ were calculated at $77 \mathrm{~K}$ with equilibration steps $=10^{5}$ and production steps $=10^{6}$. Universal force field (UFF) was used for energy calculations, and Ewald \& group method was applied to compute electrostatic interactions. For the final isotherm line, the fugacity and average loading (per cell) units were transformed into $P / P_{0}$ and $\mathrm{cm}^{3} \mathrm{~g}^{-1}$ (STP), respectively. The BET surface area is obtained from the simulated adsorption isotherm by using BET model in the pressure range of $0.05<P / P_{0}<0.30$.

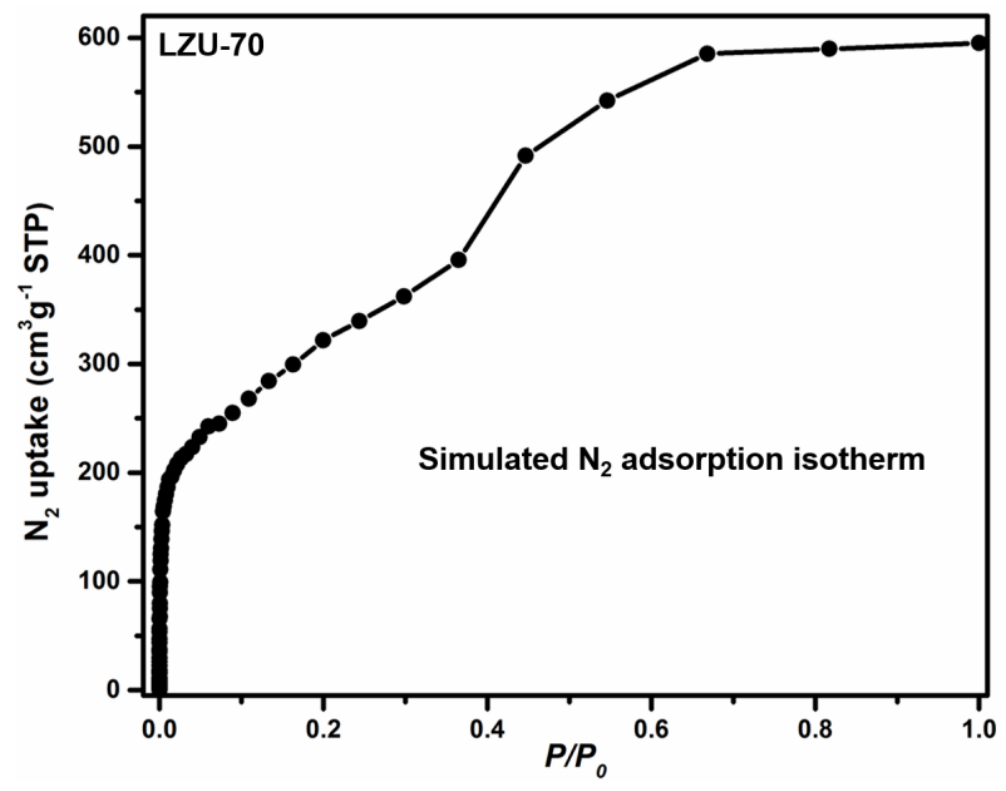

Figure S9. Simulated nitrogen adsorption isotherm of LZU-70.

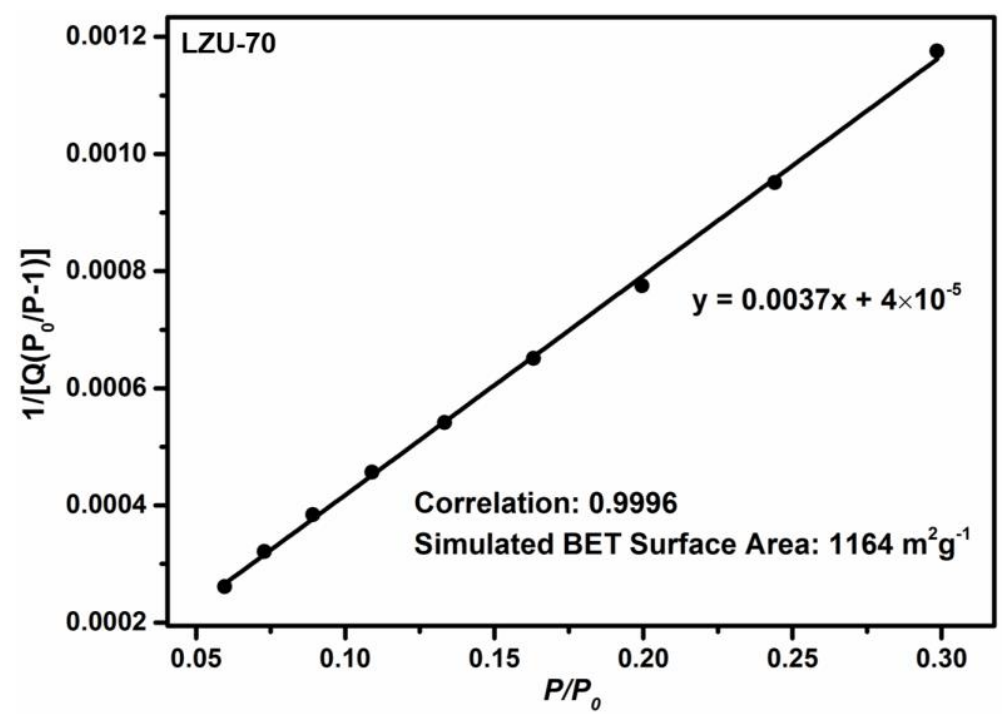

Figure S10. Simulated BET surface area plot for LZU-70. The $V_{\mathrm{m}}=267.4 \mathrm{~cm}^{3} \mathrm{~g}^{-1}$ (STP). 


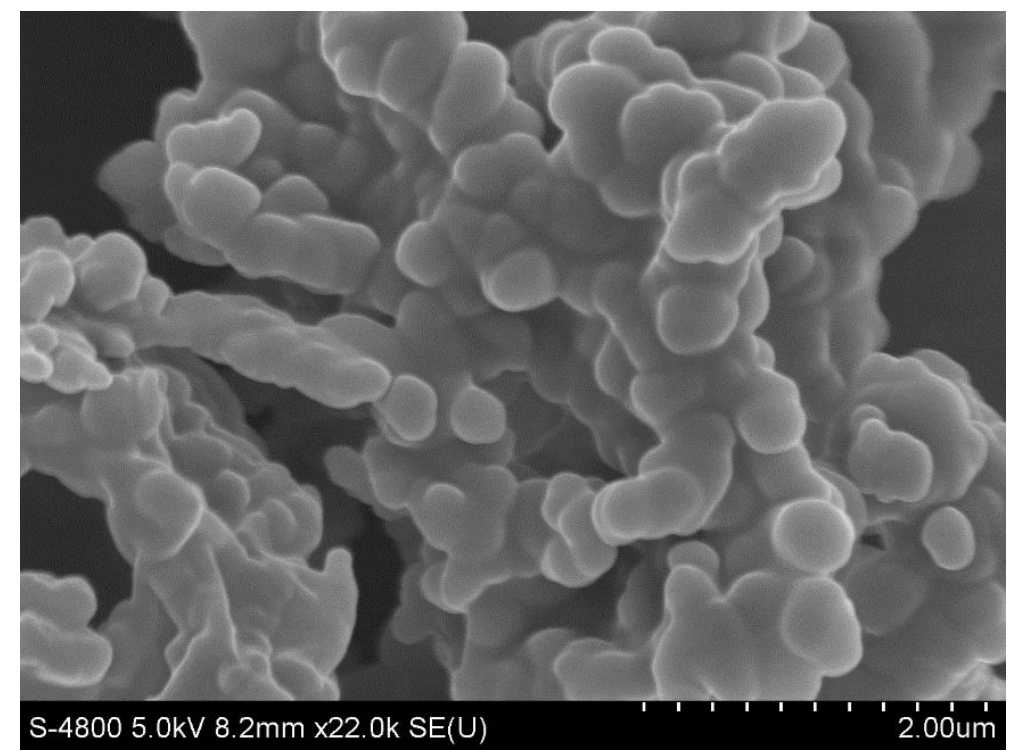

Figure S11. SEM image of LZU-70. The image showed that LZU-70 adopted a sphere-like morphology with an average particle size of ca. $300 \mathrm{~nm}$.

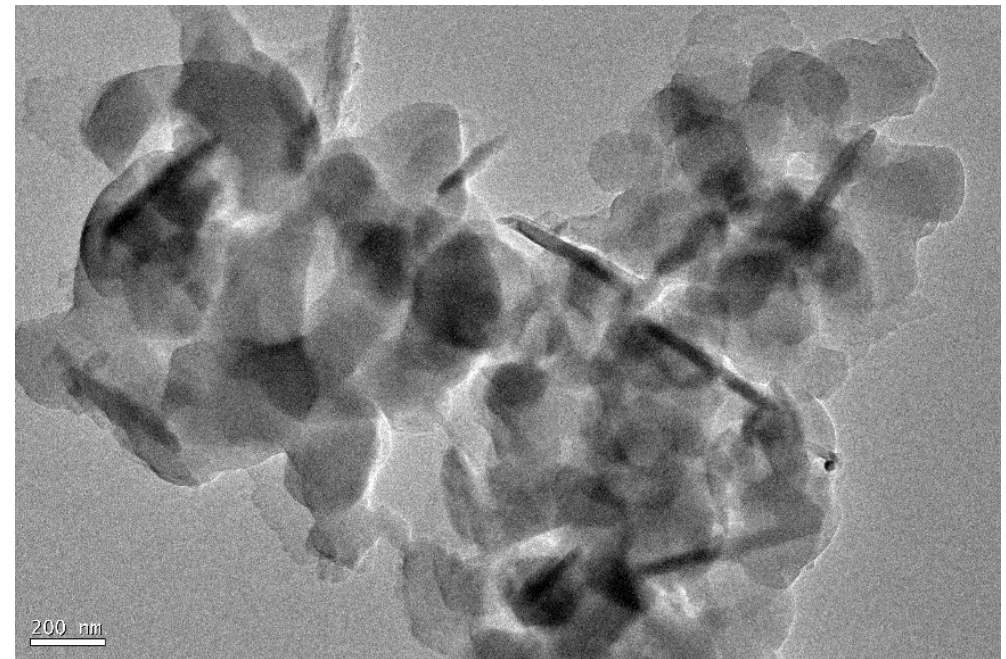

Figure S12. TEM image of LZU-70. 


\section{Structural modeling of LZU-70}

Structural modeling of LZU-70 was generated using the Materials Studio (ver. 7.0) suite of programs. Molecular geometry optimization was performed with $\mathrm{MS}^{\mathrm{DMol}}{ }^{3}$ module. The initial lattice was created by starting with the space group $P-6$. The $a$ and $b$ lattice parameters (initially $37.3084 \AA$ ) were estimated according to the center to center distance between the vertices of the COF (TFB center to another TFB center). The constructed model was geometry optimized using the Forcite module (Universal force fields, Ewald summations). Then the calculated PXRD pattern was generated with the Reflex Plus module. Finally, Pawley refinement was applied for profile fitting, producing the refined PXRD profile with the lattice parameters of $a=b=38.1506( \pm 0.0003)$ $\AA$ and $c=3.4357( \pm 0.0021) \AA . R_{\mathrm{wp}}$ and $R_{\mathrm{p}}$ values converged to $7.88 \%$ and $6.48 \%$, respectively. A staggered arrangement for LZU-70 was also constructed with the space group P63 wherein the stacked units were offset by $a / 2$ and $b / 2$. Comparison of the observed and the simulated PXRD patterns (Figure S13) suggested that the preferable structure of LZU-70 is the eclipsed arrangement.
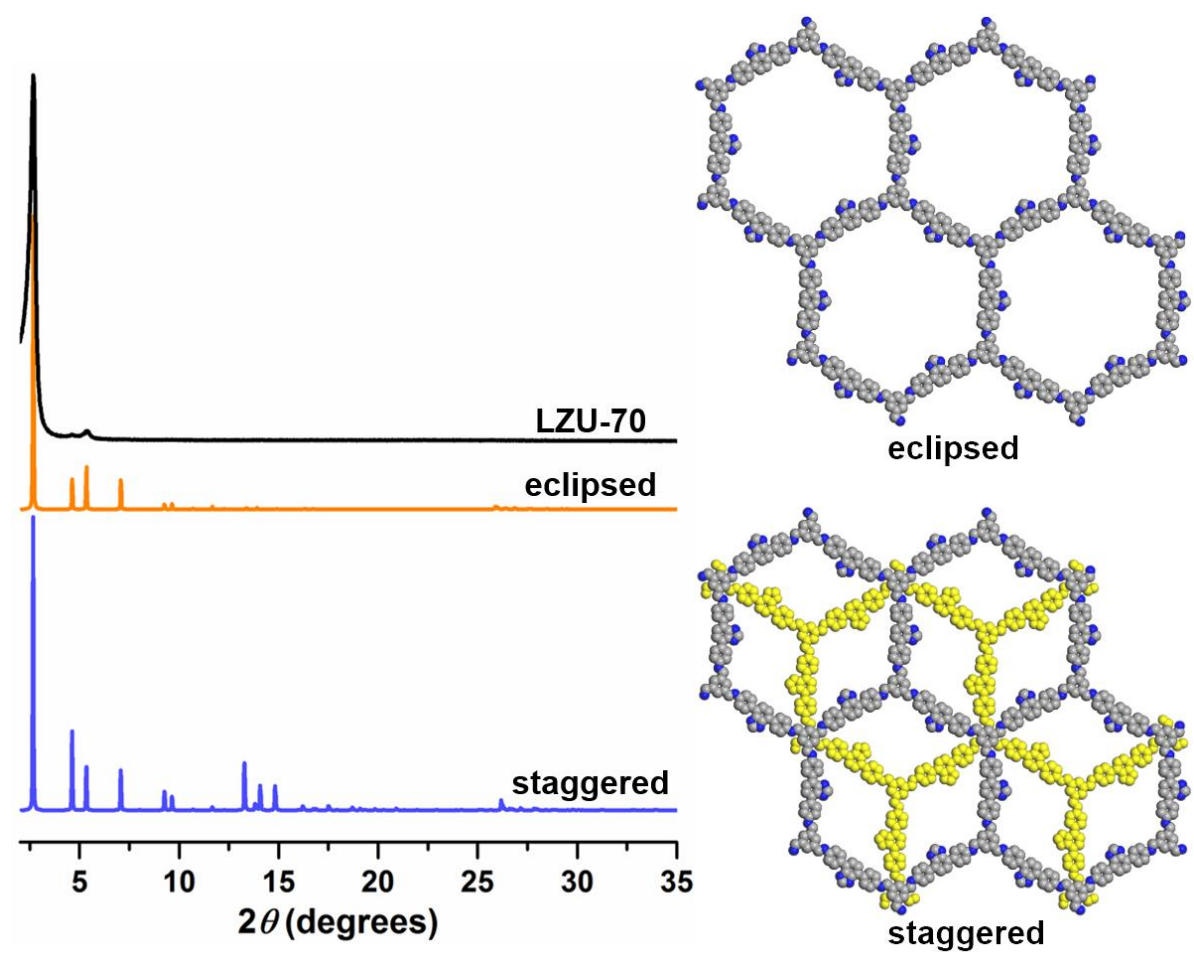

Figure S13. Left: PXRD patterns of LZU-70 observed (black) and calculated with the eclipsed (orange) or staggered (blue) stacking models. Right: Graphic views of eclipsed (top) or staggered (bottom) models. Comparison of the observed and the simulated PXRD patterns suggested that the preferable structure of LZU-70 is the eclipsed arrangement. 


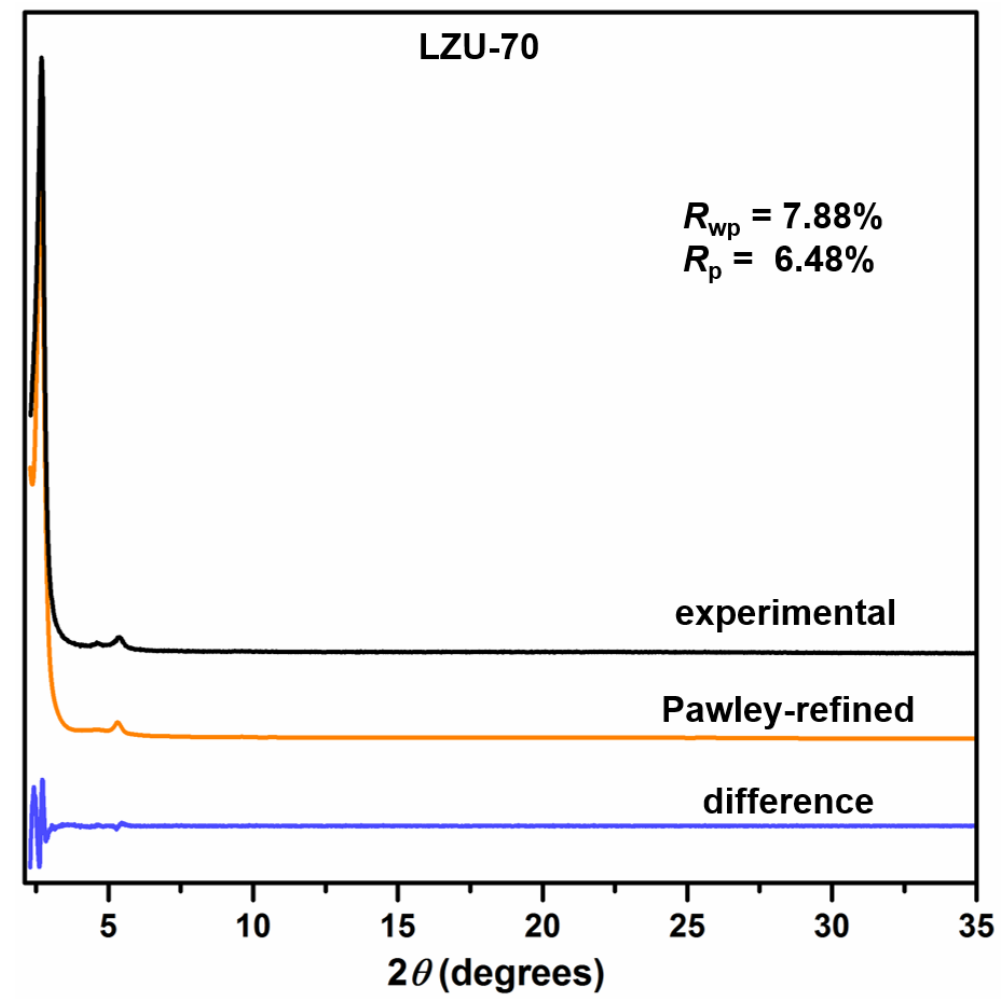

Figure S14: Experimental (black) and Pawley-refined (orange) PXRD patterns of LZU-70 based on the eclipsed arrangement. The difference plot between the experimental and refined PXRD patterns was shown in blue. 
Table S1. Fractional atomic coordinates for the unit cell of LZU-70.

\begin{tabular}{|c|c|c|c|c|c|c|c|}
\hline \multicolumn{7}{|c|}{ LZU-70: Space group symmetry P-6 } \\
\hline \multicolumn{7}{|c|}{$\alpha=b=38.1506 \AA$ A,$C=3.4357 \AA$} \\
\hline Atom & $\mathrm{x}(\AA)$ & $\mathrm{y}(\AA)$ & $\mathrm{z}(\AA)$ & Atom & $\mathrm{x}(\AA)$ & $\mathrm{y}(\AA)$ & $\mathrm{z}(\AA)$ \\
\hline C1 & 0.31014 & -0.85658 & 0 & $\mathrm{C} 24$ & 0.62428 & -0.67879 & 0 \\
\hline C2 & 0.35239 & -0.83798 & 0 & $\mathrm{~N} 25$ & 0.37466 & -0.73084 & 0 \\
\hline C3 & 0.37783 & -0.7956 & 0 & $\mathrm{C} 26$ & 0.34504 & -0.72371 & 0 \\
\hline C4 & 0.35706 & -0.7736 & 0 & $\mathrm{~N} 27$ & 0.30636 & -0.75923 & 0 \\
\hline C5 & 0.31498 & -0.79169 & 0 & $\mathrm{C} 28$ & 0.02615 & -0.95695 & 0 \\
\hline C6 & 0.28892 & -0.83479 & 0 & $\mathrm{C} 29$ & 0.63565 & -0.70844 & 0 \\
\hline C7 & 0.24237 & -0.85859 & 0 & $\mathrm{H} 30$ & 0.29533 & -0.88895 & 0 \\
\hline C8 & 0.42386 & -0.7766 & 0 & $\mathrm{H} 31$ & 0.36393 & -0.85851 & 0 \\
\hline C9 & 0.44223 & -0.80105 & 0 & $\mathrm{H} 32$ & 0.4253 & -0.83353 & 0 \\
\hline C10 & 0.4842 & -0.78422 & 0 & $\mathrm{H} 33$ & 0.4969 & -0.80404 & 0 \\
\hline C11 & 0.50984 & -0.74248 & 0 & $\mathrm{H} 34$ & 0.51115 & -0.68493 & 0 \\
\hline C12 & 0.49268 & -0.71748 & 0 & $\mathrm{H} 35$ & 0.44088 & -0.71241 & 0 \\
\hline C13 & 0.45068 & -0.73417 & 0 & $\mathrm{H} 36$ & 0.22994 & -0.80871 & 0 \\
\hline C14 & 0.21819 & -0.84014 & 0 & $\mathrm{H} 37$ & 0.15889 & -0.84683 & 0 \\
\hline C15 & 0.17595 & -0.86255 & 0 & $\mathrm{H} 38$ & 0.16405 & -0.9567 & 0 \\
\hline C16 & 0.15552 & -0.90459 & 0 & $\mathrm{H} 39$ & 0.23462 & -0.91999 & 0 \\
\hline C17 & 0.17827 & -0.92413 & 0 & $\mathrm{H} 40$ & 0.09914 & -0.98544 & 0 \\
\hline C18 & 0.22053 & -0.90174 & 0 & $\mathrm{H} 41$ & 0.57466 & -0.66526 & 0 \\
\hline N19 & 0.112 & -0.92573 & 0 & $\mathrm{H} 42$ & 0.34946 & -0.69342 & 0 \\
\hline N20 & 0.55277 & -0.72723 & 0 & $\mathrm{H} 43$ & 0.28041 & -0.75713 & 0 \\
\hline C21 & 0.08771 & -0.96466 & 0 & $\mathrm{H} 44$ & 0.0452 & -0.92434 & 0 \\
\hline C22 & 0.04347 & -0.98176 & 0 & $\mathrm{H} 45$ & 0.61284 & -0.74022 & 0 \\
\hline C23 & 0.5814 & -0.68957 & 0 & & & & \\
\hline
\end{tabular}




\section{Synthesis, Characterization, and Structural Modeling of LZU-72-Boc and LZU-72}

\section{Synthesis of LZU-72-Boc and LZU-72}

Scheme S2. Synthesis of LZU-72-Boc and LZU-72.

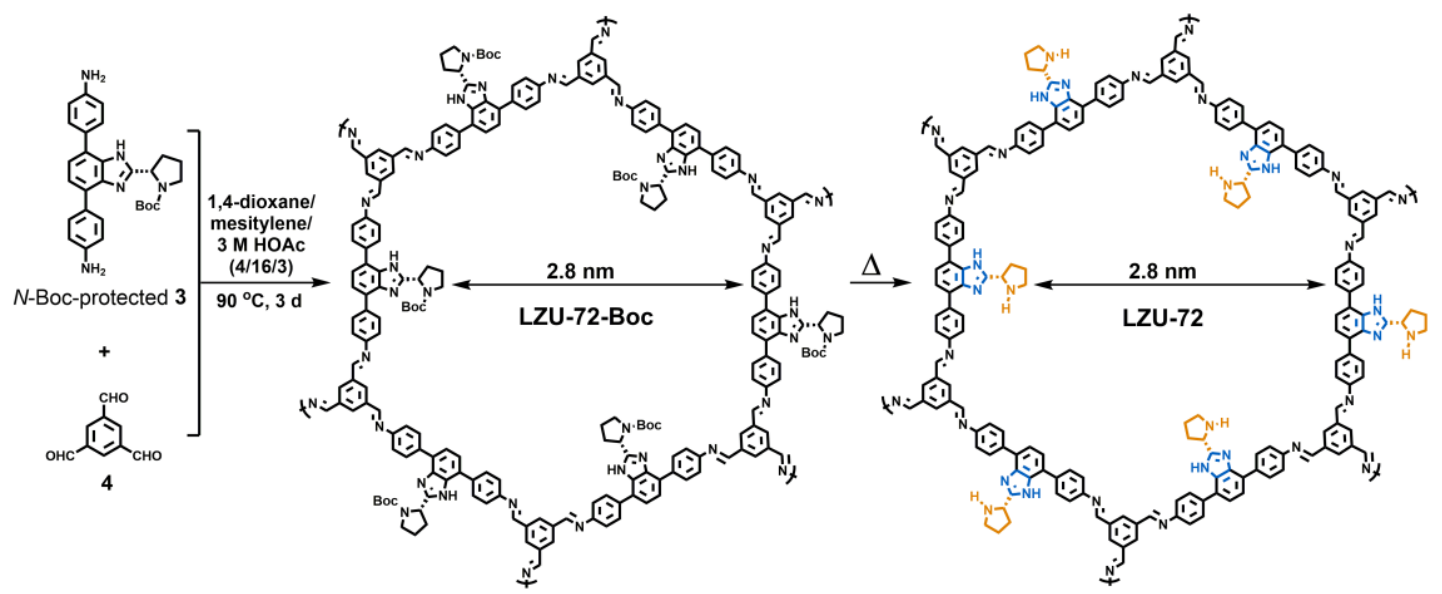

LZU-72-Boc. Monomer $4(8.1 \mathrm{mg}, 0.050 \mathrm{mmol})$ and $\mathrm{N}$-Boc-protected $3(35.2 \mathrm{mg}, 0.075 \mathrm{mmol})$ were weighed into a $10 \mathrm{~mL}$ pressure tube. To the mixture were added $0.2 \mathrm{~mL}$ of 1,4-dioxane, 0.8 $\mathrm{mL}$ of mesitylene, and $0.15 \mathrm{~mL}$ of $3 \mathrm{M}$ aqueous acetic acid. The tube was temporally sealed with a rubber plug and subsequently was flushed three times in argon/vacuum cycles. Then the sealed tube was placed in an oven at $90^{\circ} \mathrm{C}$ and left undisturbed for 3 days, yielding a yellow solid at the bottom of the tube. The tube was opened when the mixture was still warm $\left(\mathrm{ca} .40^{\circ} \mathrm{C}\right)$ and the solid was transformed into a vial, separated by centrifugation, washed with THF $(3 \times 6 \mathrm{~mL})$ and acetone $(3 \times 6 \mathrm{~mL})$, and dried at $90{ }^{\circ} \mathrm{C}$ under vacuum for $12 \mathrm{~h}$ to afford LZU-72-Boc as a yellow powder (29.8 mg, 73\% yield). Further purification of LZU-72-Boc was carried out by Soxhlet extraction in THF for 24 h. Anal. Cald for $\left(\mathrm{C}_{34} \mathrm{H}_{31} \mathrm{~N}_{5} \mathrm{O}_{2}\right)_{n}$ : C 75.42; H 5.73; N 12.94. Found: C 73.26; H 5.20; N 11.85. IR (powder, $\mathrm{cm}^{-1}$ ) 3430, 2973, 2930, 2876, 1702, 1675, 1625, 1521, 1488, 1400, 1366, $1162,812$.

LZU-72. To a $10 \mathrm{~mL}$ pressure tube was added LZU-72-Boc $(20 \mathrm{mg})$, and the tube was temporally sealed with a rubber plug and subsequently was flushed three times in argon/vacuum cycles. Then the sealed tube was heated at $245{ }^{\circ} \mathrm{C}$ for $15 \mathrm{~min}$ in a preheated oven. After cooling to room temperature, the tube was opened and the solid was transformed into a vial, and washed with THF $(3 \times 6 \mathrm{~mL})$. The resulting powder was dried at room temperature, and then in vacuum at $90^{\circ} \mathrm{C}$ for $12 \mathrm{~h}$ to afford LZU-72 as an orange powder ( $15.6 \mathrm{mg}, 96 \%$ yield). Further purification of LZU-72 was carried out by Soxhlet extraction in THF for $24 \mathrm{~h}$. Anal. Cald for $\left(\mathrm{C}_{29} \mathrm{H}_{23} \mathrm{~N}_{5}\right)_{\mathrm{n}}$ : C 78.91; H 5.22; N 15.87. Found: C 76.24; H 4.48; N 14.49. IR (powder, $\mathrm{cm}^{-1}$ ) 3411, 2965, 2871, 1621, 1522, 1488 , 1422, 1364, 1318, 1142, 811, 684.

The molecular connectivity, crystallinity, thermal stability, porosity, and morphology of LZU-72-Boc and LZU-72 were investigated in details, and the results are shown in the following. 


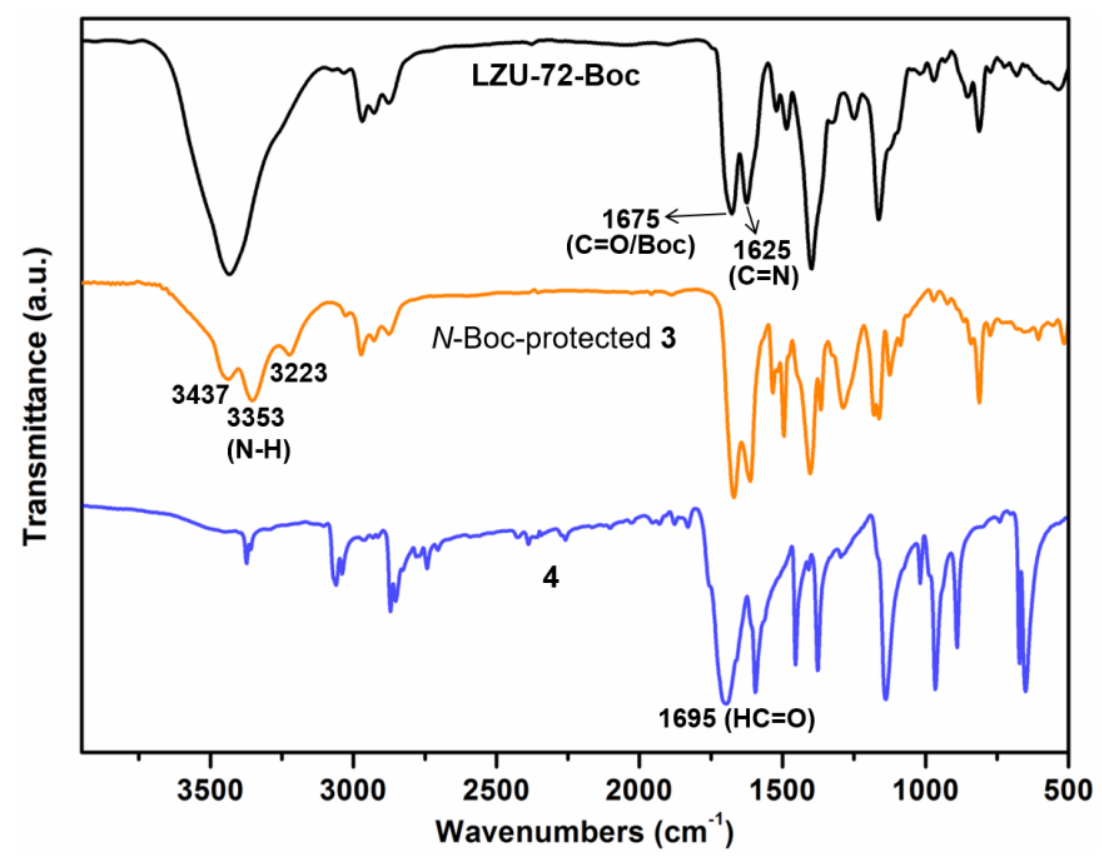

Figure S15. FT-IR spectra of LZU-72-Boc (black), N-Boc-protected $\mathbf{3}$ (orange), and monomer $\mathbf{4}$ (blue).

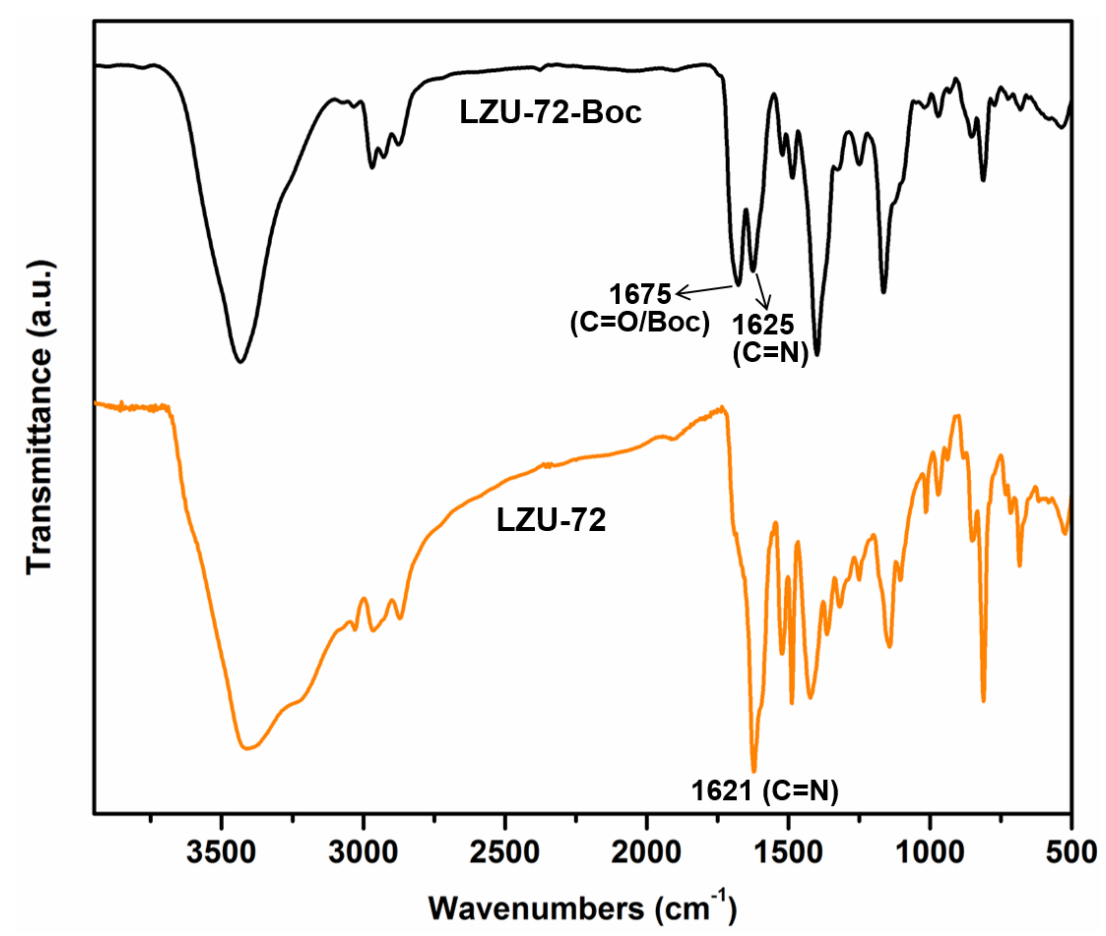

Figure S16. FT-IR spectra of LZU-72-Boc (black) and LZU-72 (orange). The carbonyl stretching band $\left(1675 \mathrm{~cm}^{-1}\right)$ of LZU-72 (orange) was greatly attenuated in comparison with that of LZU-72-Boc (black), indicating the successful deprotection of the Boc groups. 


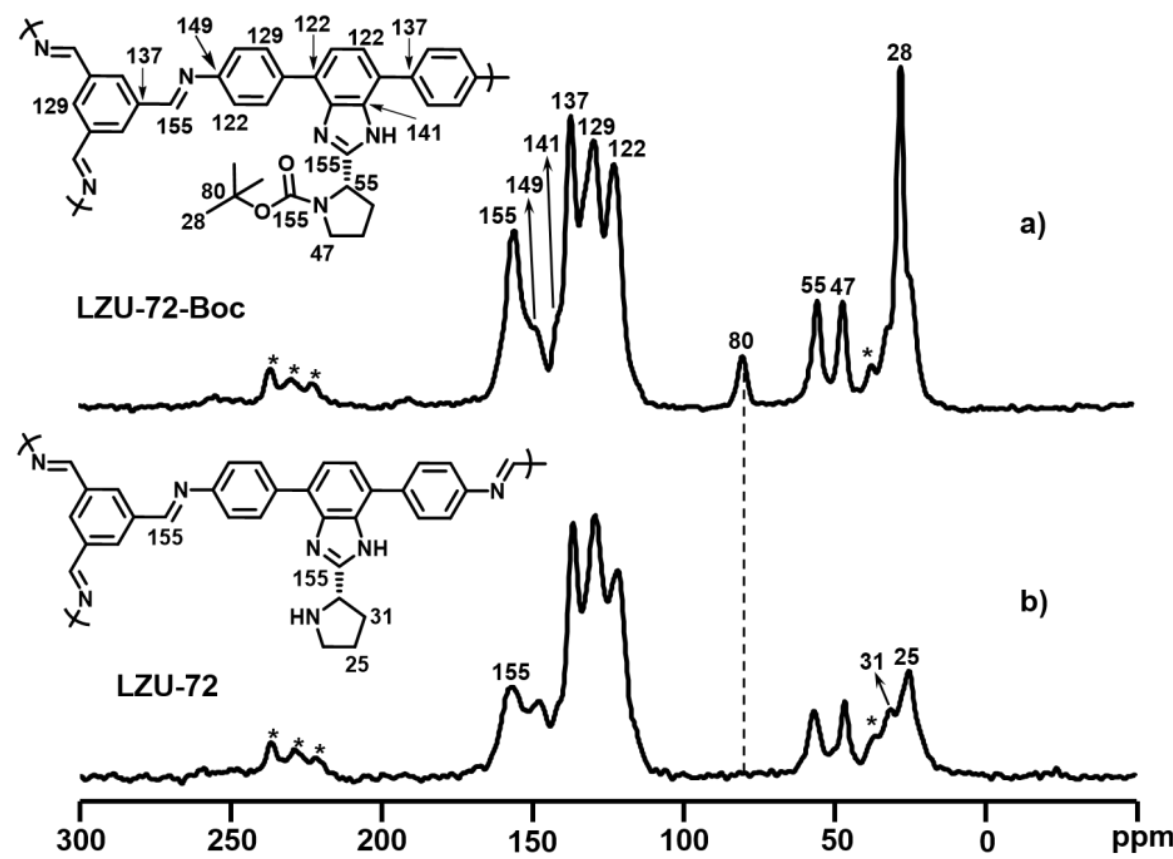

Figure S17. ${ }^{13} \mathrm{C}$ CP/MAS NMR spectra of LZU-72-Boc (a) and LZU-72 (b). The asterisks denote the spinning sidebands. The assignments of ${ }^{13} \mathrm{C}$ chemical shifts are indicated in the chemical structures. In the ${ }^{13} \mathrm{C}$ CP/MAS NMR spectrum of LZU-72-Boc (a), the signals at $\delta=28,47,55$, and $80 \mathrm{ppm}$ are due to the carbon atoms of $\mathrm{N}$-Boc-pyrrolidine moiety, indicating that $\mathrm{N}$-Boc-protected 3 has well been embedded into the framework of LZU-72-Boc. In the ${ }^{13} \mathrm{C} C P / M A S$ NMR spectrum of LZU-72 (b), the signal at $\delta=80 \mathrm{ppm}$, which corresponds to the quaternary carbon of the tert-butyl on the Boc groups, disppeared, indicating the successful deprotection of the Boc groups. 


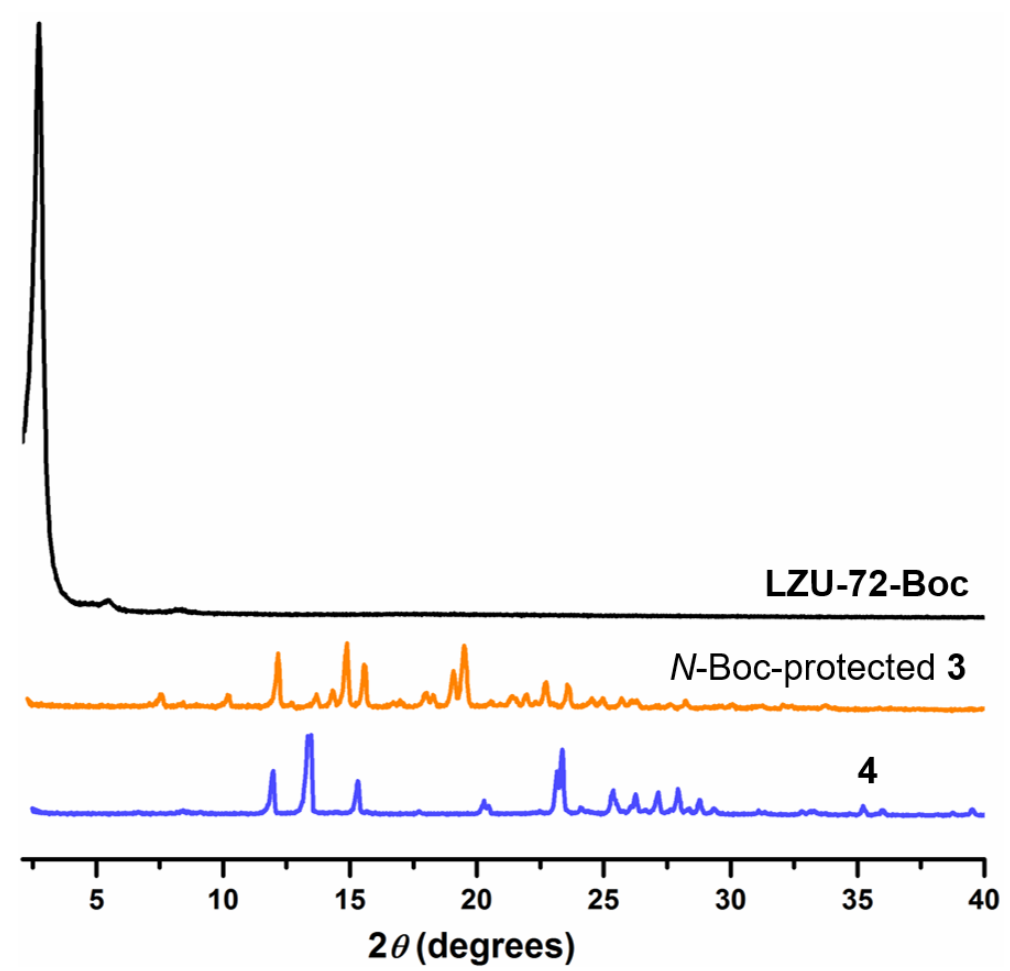

Figure S18. PXRD patterns of LZU-72-Boc (black), N-Boc-protected 3 (orange), and monomer 4 (blue). No diffraction peaks from $N$-Boc-protected 3 (orange) or monomer 4 (blue) could be observed in the PXRD pattern of LZU-72-Boc (black), indicating the sole formation of the crystalline LZU-72-Boc material.

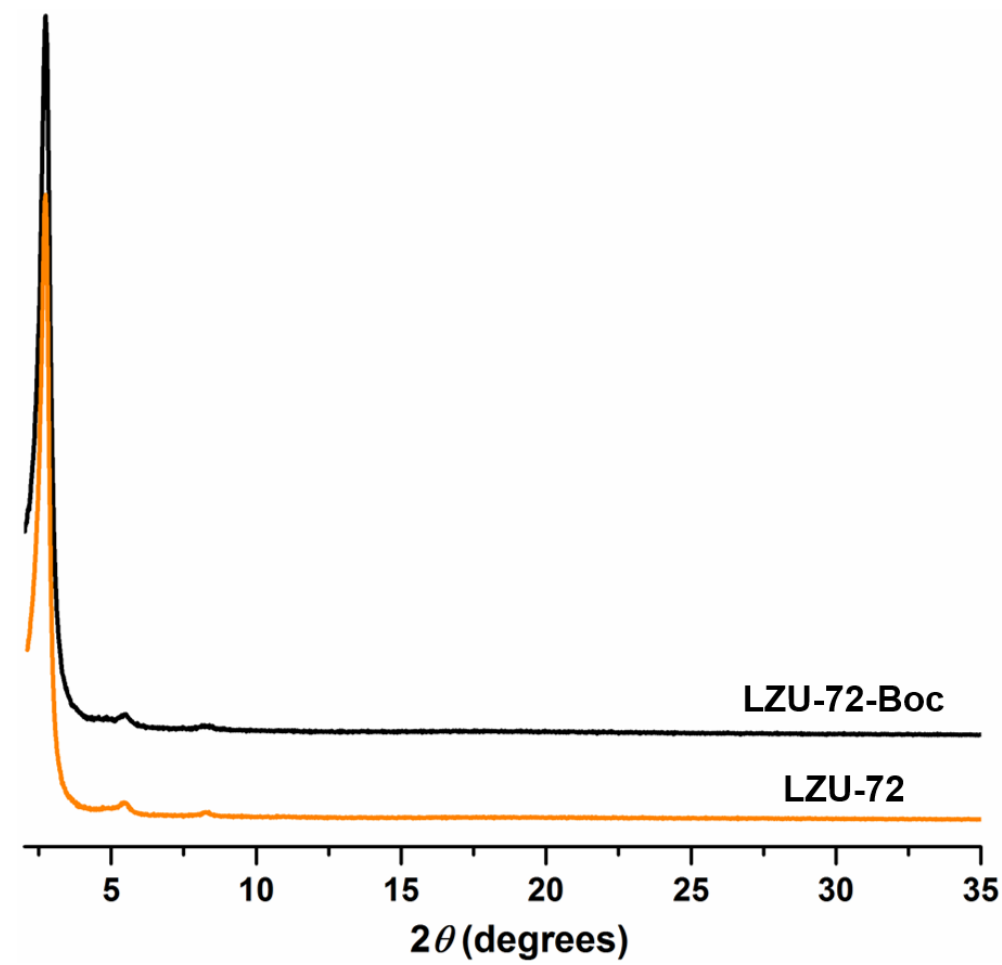

Figure S19. PXRD patterns of LZU-72-Boc (black) and LZU-72 (orange). The PXRD pattern of LZU-72 (orange) is almost identical to that of LZU-72-Boc (black), indicating that the crystallinity of LZU-72 was well maintained. 


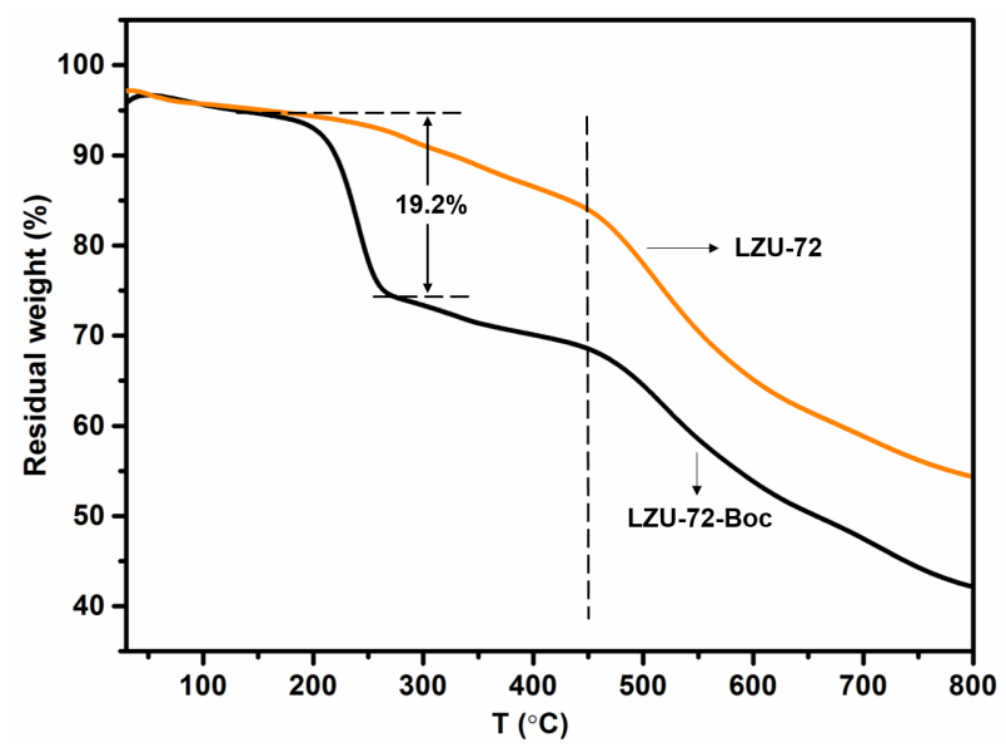

Figure S20. TGA data of LZU-72-Boc (black) and LZU-72 (orange). TGA analysis indicates that both COFs are thermally stable up to $450{ }^{\circ} \mathrm{C}$. The significant weight loss $(19.2 \%)$ in the region of $185-272{ }^{\circ} \mathrm{C}$ in the TGA curve of LZU-72-Boc (black) corresponds to the deprotection of the Boc groups (theoretical value of $18.5 \%$ ).

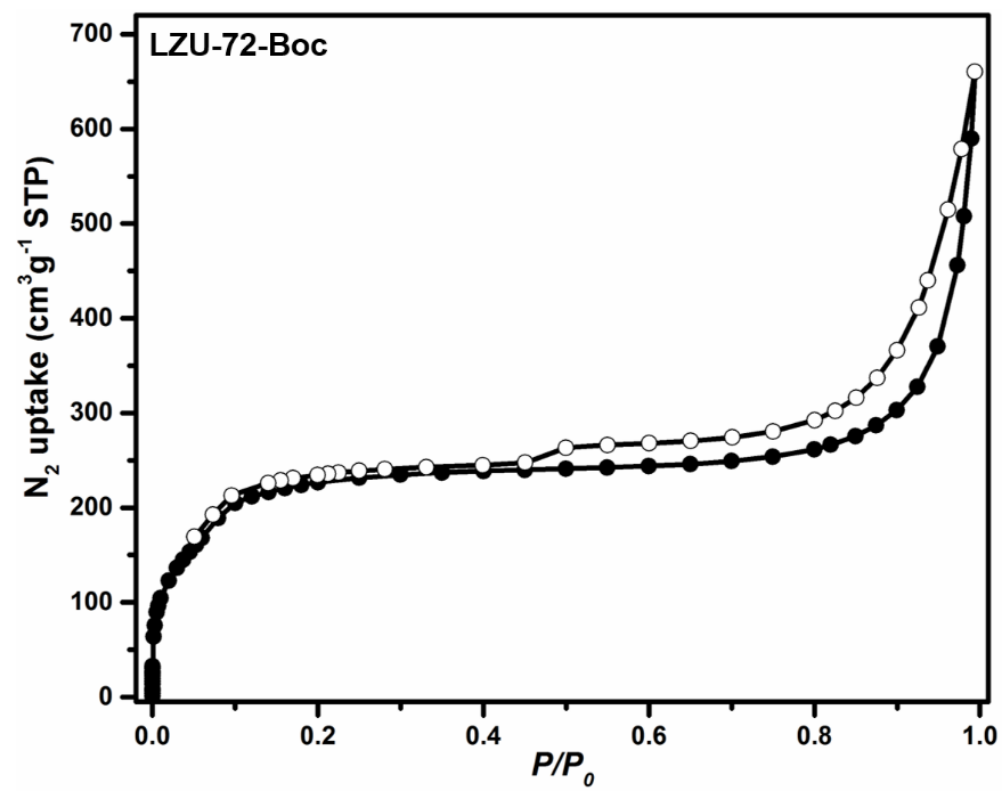

Figure S21. Nitrogen adsorption (filled symbols) and desorption (empty symbols) isotherms of LZU-72-Boc. 


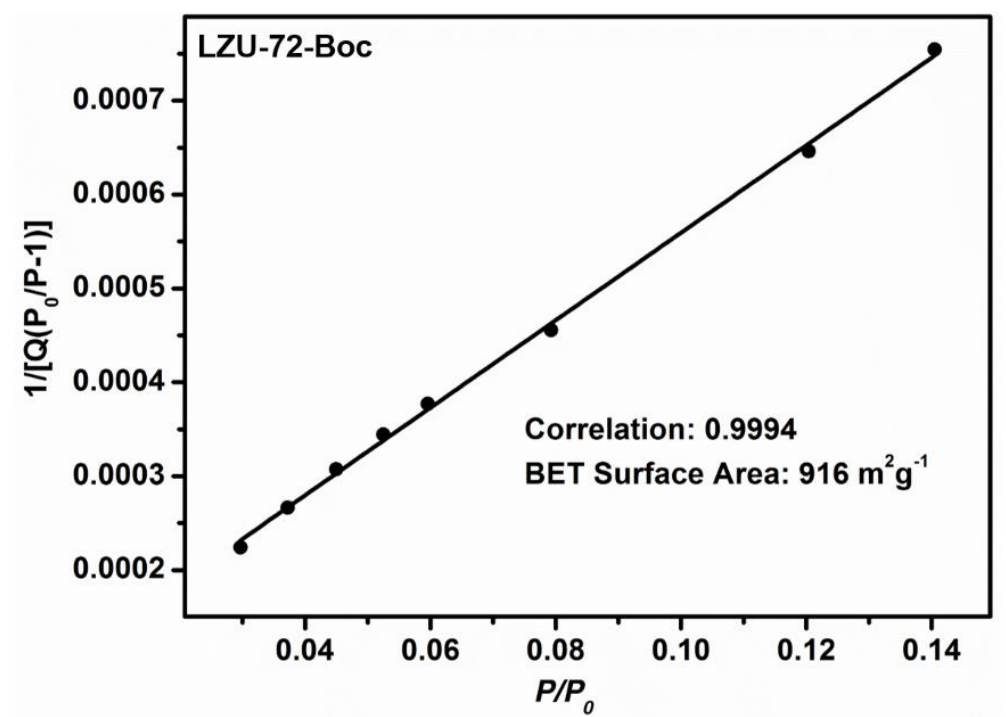

Figure S22. BET surface area plot for LZU-72-Boc calculated from the $\mathrm{N}_{2}$ absorption isotherm.

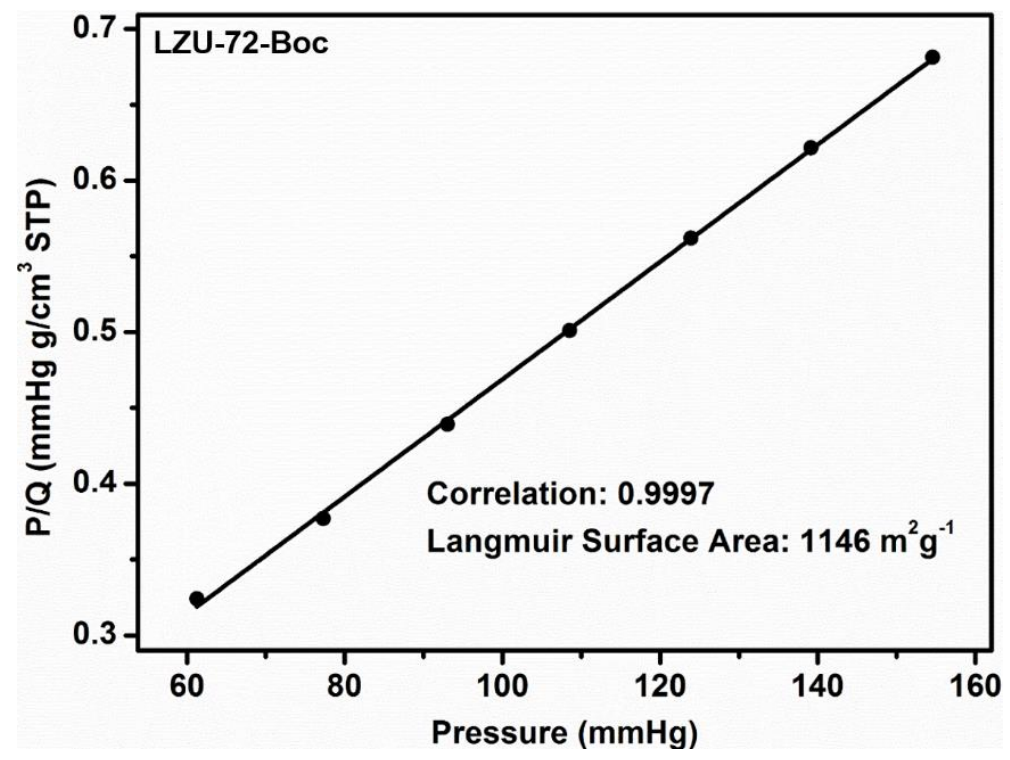

Figure S23. Langmuir surface area plot for LZU-72-Boc calculated from the $\mathrm{N}_{2}$ absorption isotherm. 


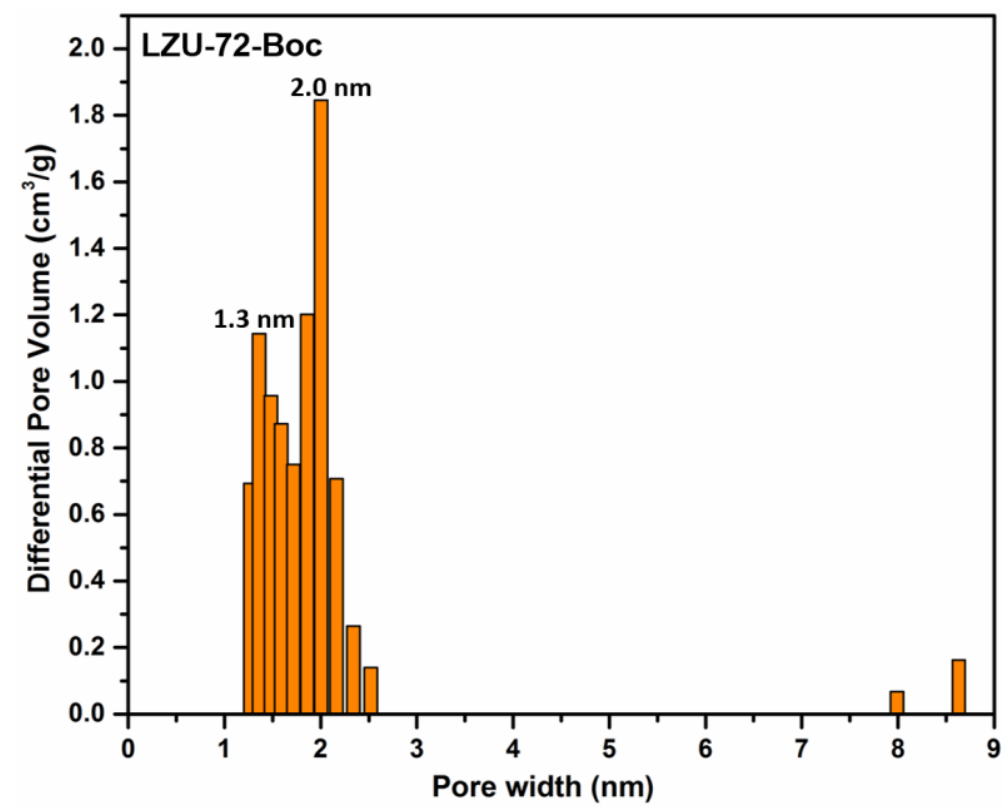

Figure S24. Pore size distribution of LZU-72-Boc calculated by NLDFT (slit pores model).

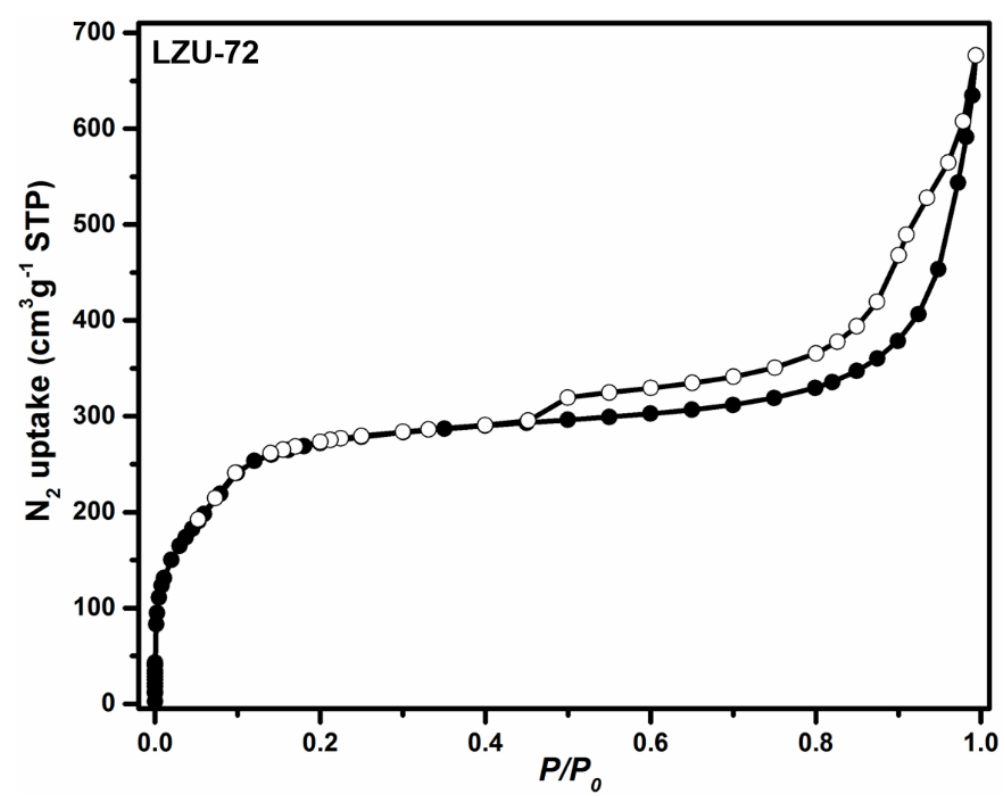

Figure S25. Nitrogen adsorption (filled symbols) and desorption (empty symbols) isotherms of LZU-72. 


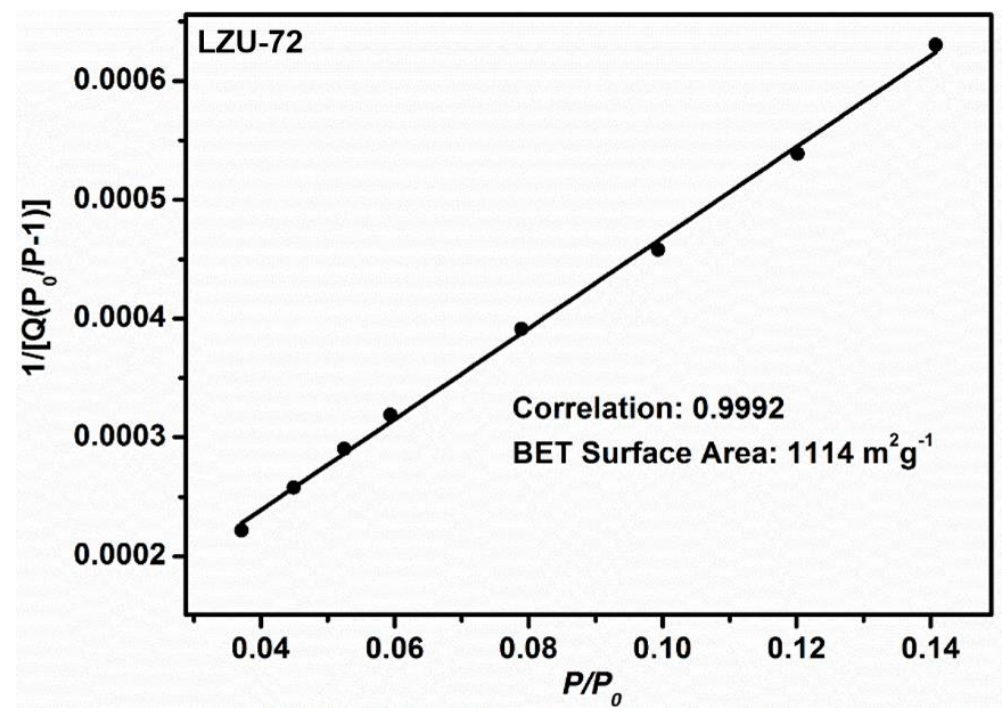

Figure S26. BET surface area plot for LZU-72 calculated from the $\mathrm{N}_{2}$ absorption isotherm.

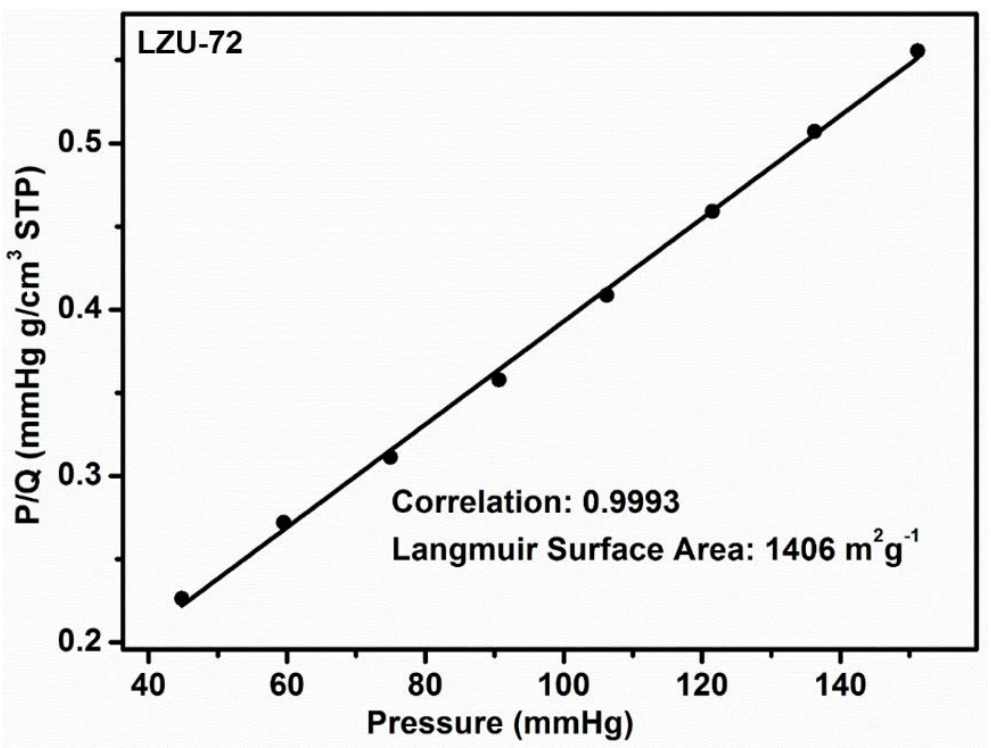

Figure S27. Langmuir surface area plot for LZU-72 calculated from the $\mathrm{N}_{2}$ absorption isotherm. 


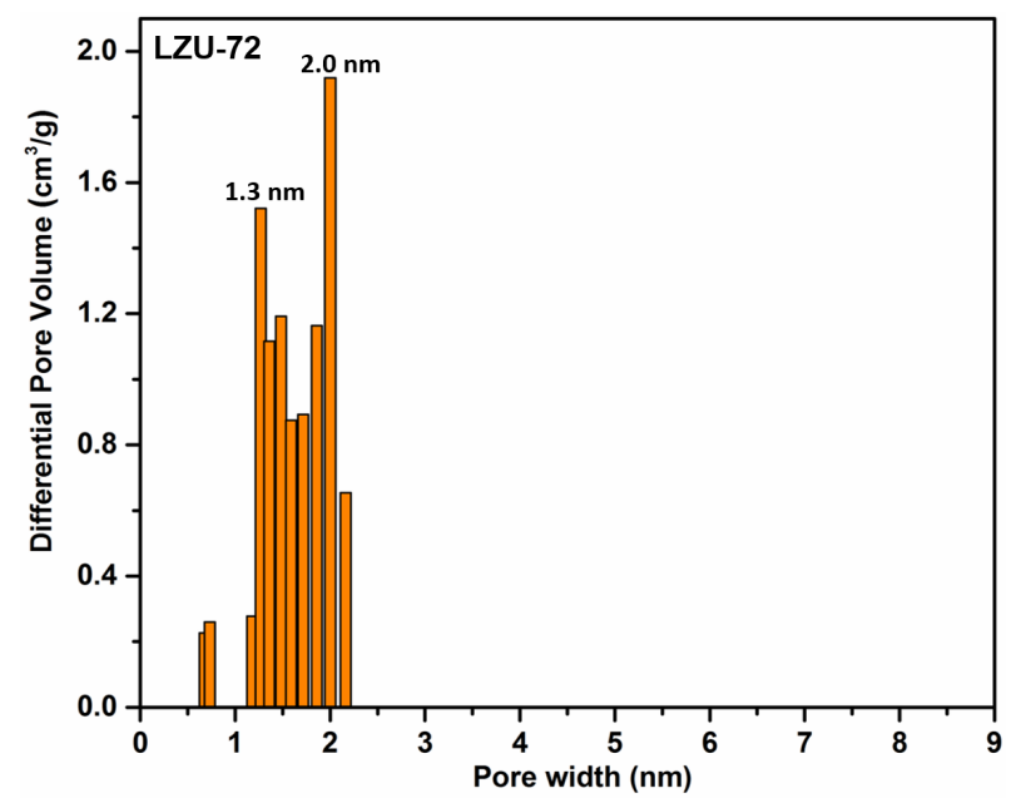

Figure S28. Pore size distribution of LZU-72 calculated by NLDFT (slit pores model). 
The single-crystal structure (Figure S29) of the monomer, $\mathrm{N}$-Boc-protected $\mathbf{3}$, indicates that the Boc group is located closely to the phenyl ring. As further shown in the simulated structures of LZU-72-Boc and LZU-72 (Figure S30), due to the parallel location of the Boc groups to the adjacent pore walls, the pore size of LZU-72-Boc (with Boc protecting group) is similar to that of LZU-72 (without Boc protecting groups).

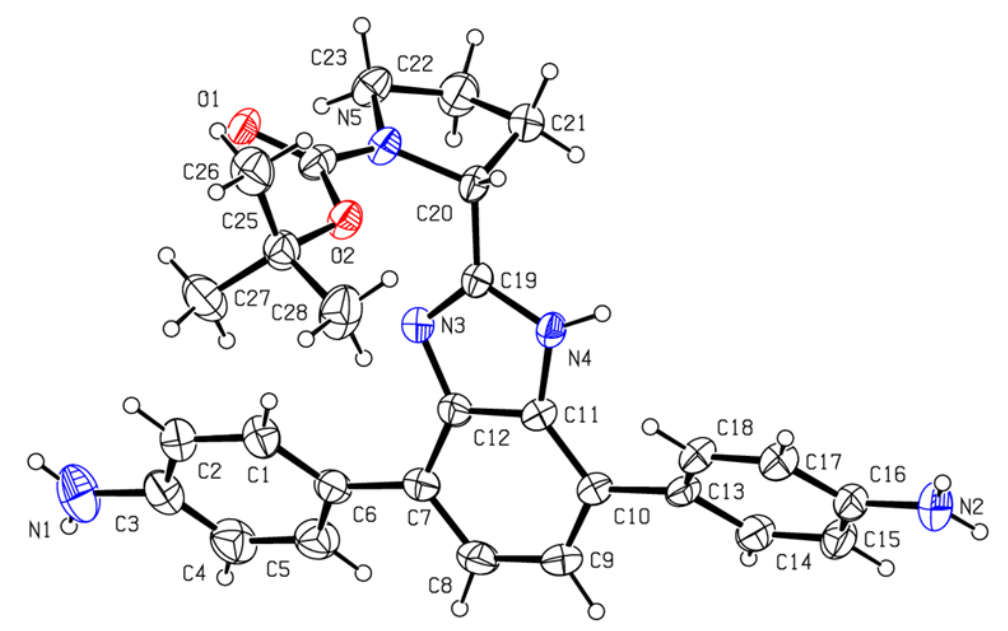

Figure S29. Single-crystal structure of the monomer, $\mathrm{N}$-Boc-protected $\mathbf{3}$. It can be seen that the $B o c$ group is located closely to the phenyl ring. CCDC 1027903 contains the supplementary crystallographic data which can be obtained free of charge from the Cambridge Crystallographic Data Centre via www.ccdc.cam.ac.uk/data_request/cif.
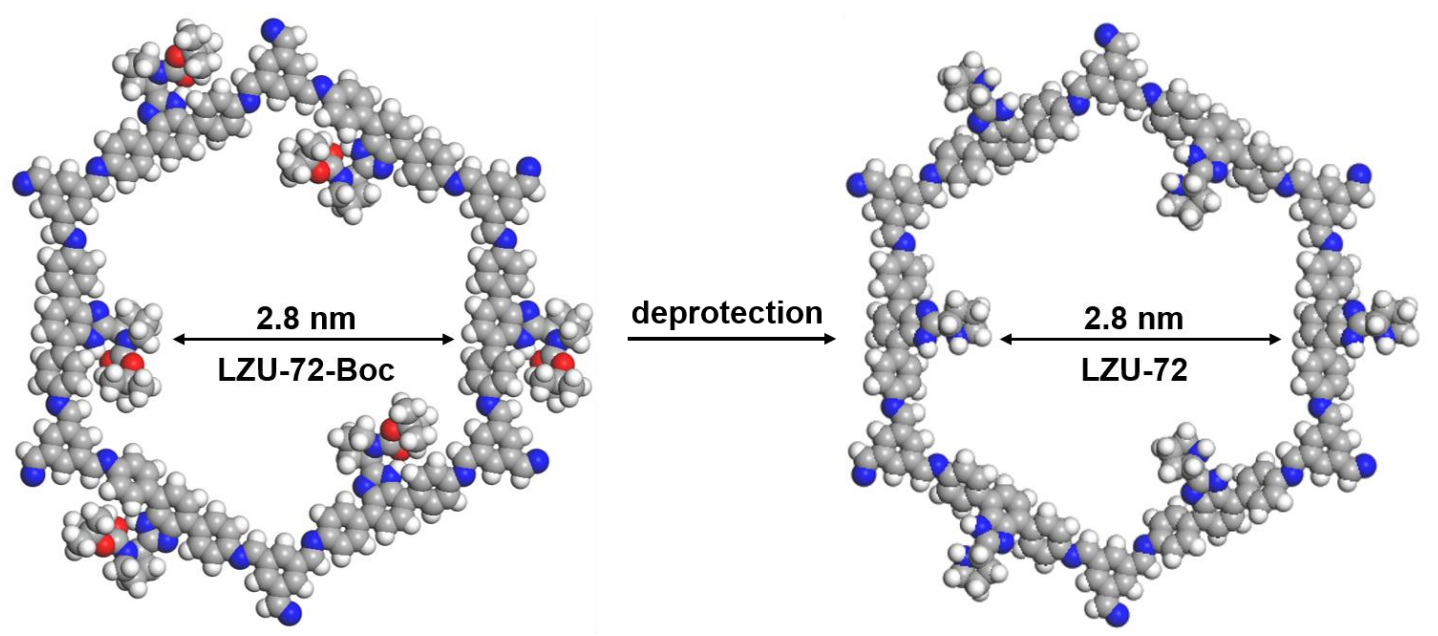

Figure S30. Pore structures of LZU-72-Boc (with Boc protecting groups) and LZU-72 (without Boc protecting groups) simulated after the geometrical energy minimization with Materials Studio. C, gray; $\mathrm{O}$, red; $\mathrm{N}$, blue; $\mathrm{H}$, white. Due to the parallel location of the Boc groups to the adjacent pore walls, the pore sizes of LZU-72-Boc and LZU-72 were almost the same. 
Simulations of the nitrogen isotherm and BET surface area of $L Z U-72$

The process for simulations of the nitrogen isotherm and BET surface area of LZU-72 was similar to that of LZU-70. The obtained results are shown in Figures S31 and S32.

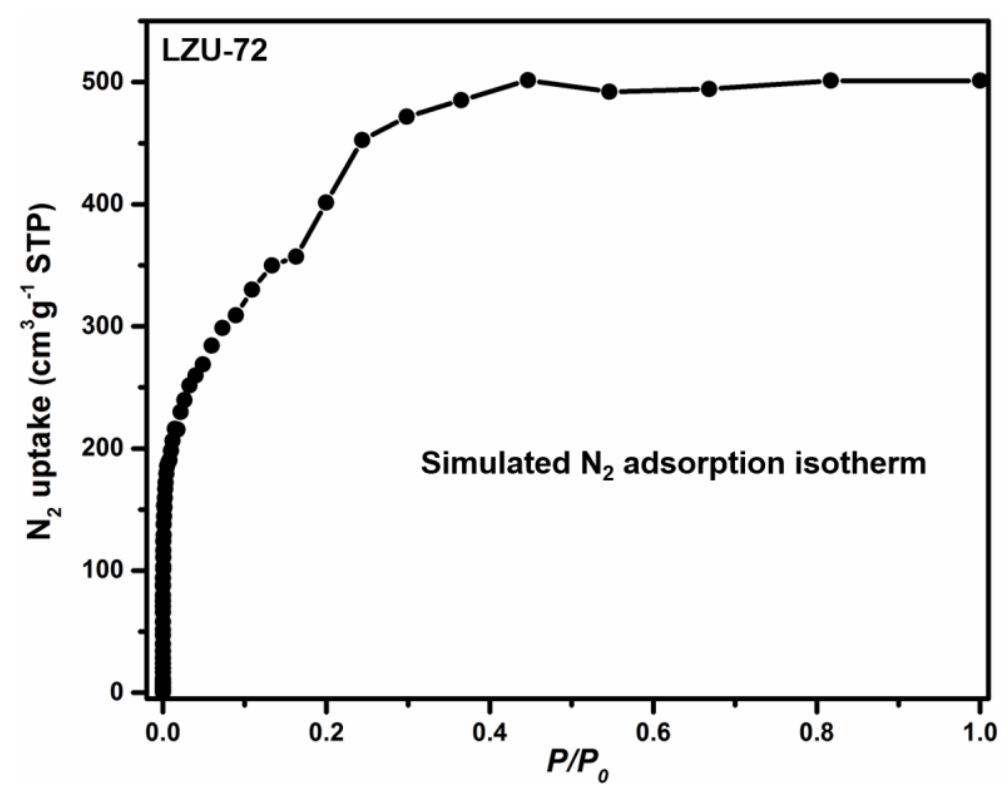

Figure S31. Simulated nitrogen adsorption isotherm of LZU-72.

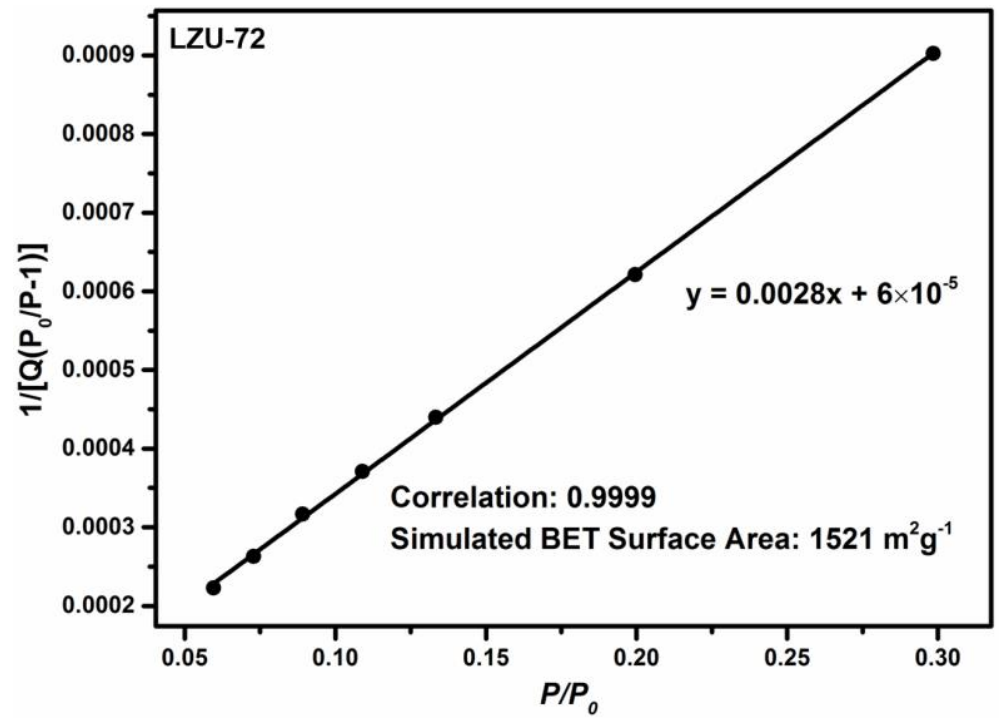

Figure S32. Simulated BET surface area plot for LZU-72. The $V_{\mathrm{m}}=349.4 \mathrm{~cm}^{3} \mathrm{~g}^{-1}(\mathrm{STP})$. 

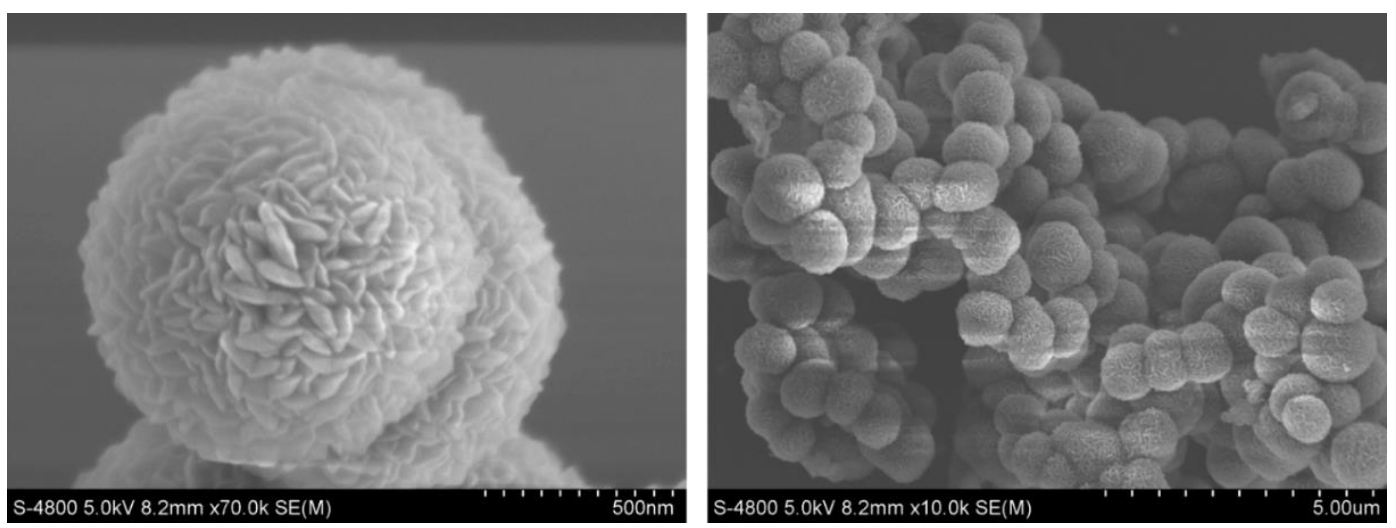

Figure S33. SEM images of LZU-72-Boc, showing that the obtained material adopted the uniform sphere-like morphology.
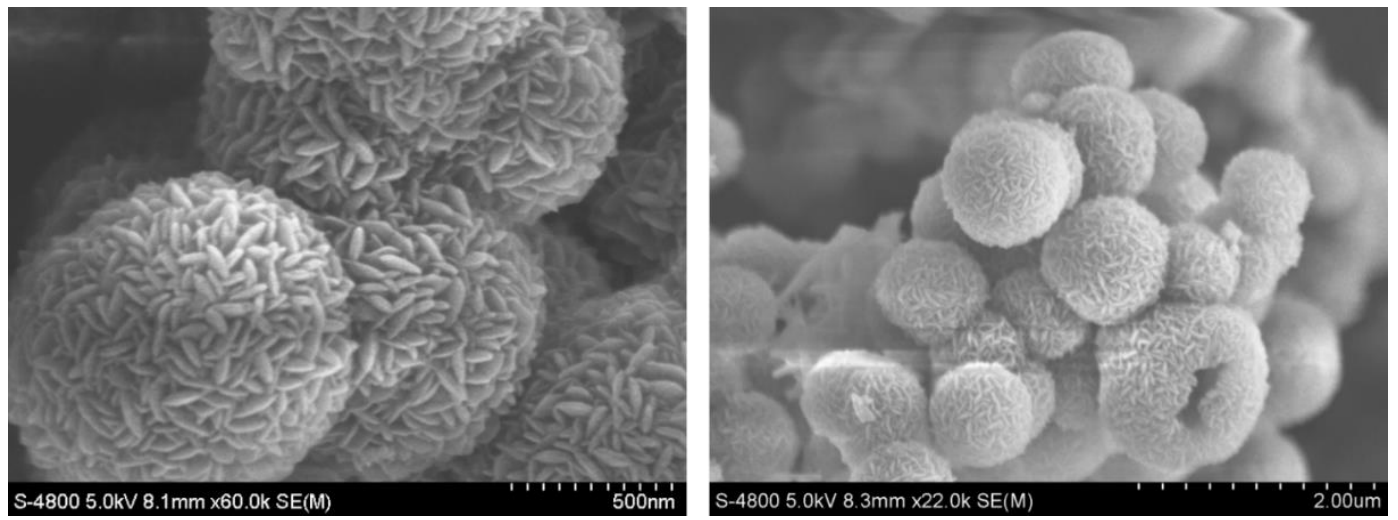

Figure S34. SEM images of LZU-72, showing that the obtained material possessed the uniform sphere-like morphology as well. 


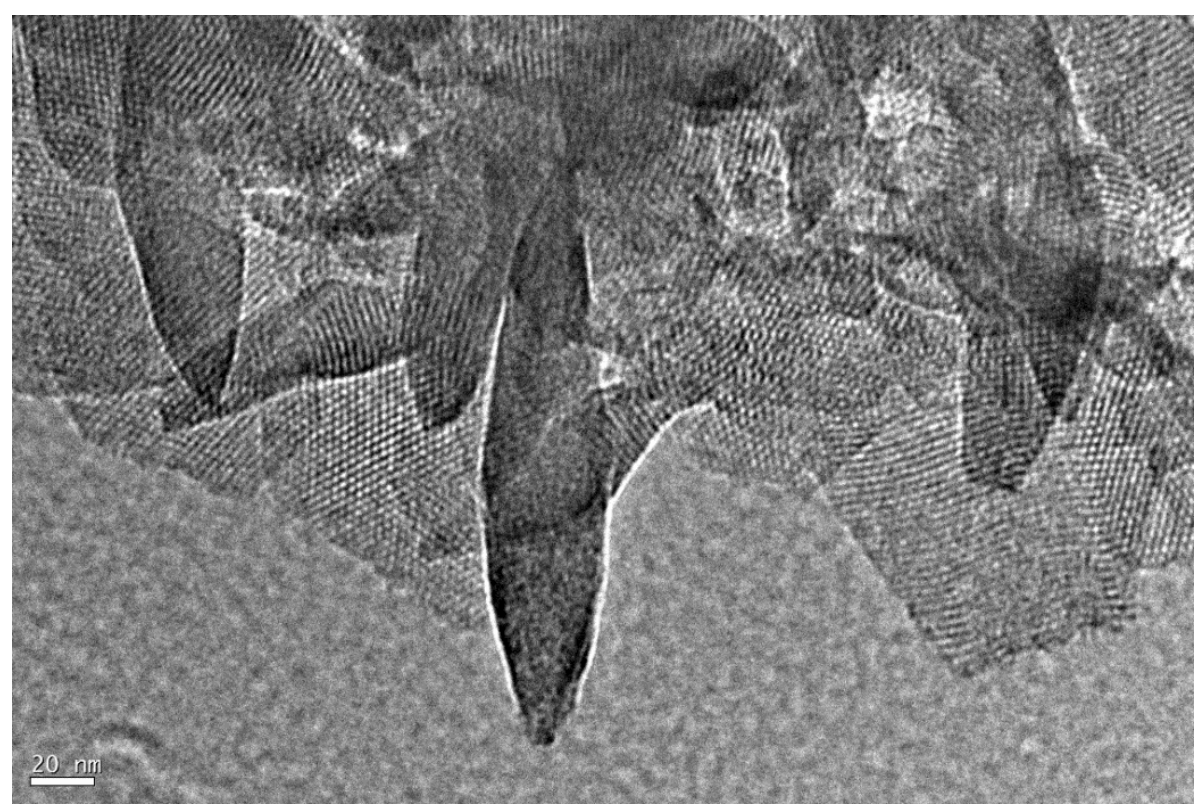

Figure S35. TEM image of LZU-72-Boc, showing the ordered channels with the distinct pore size.

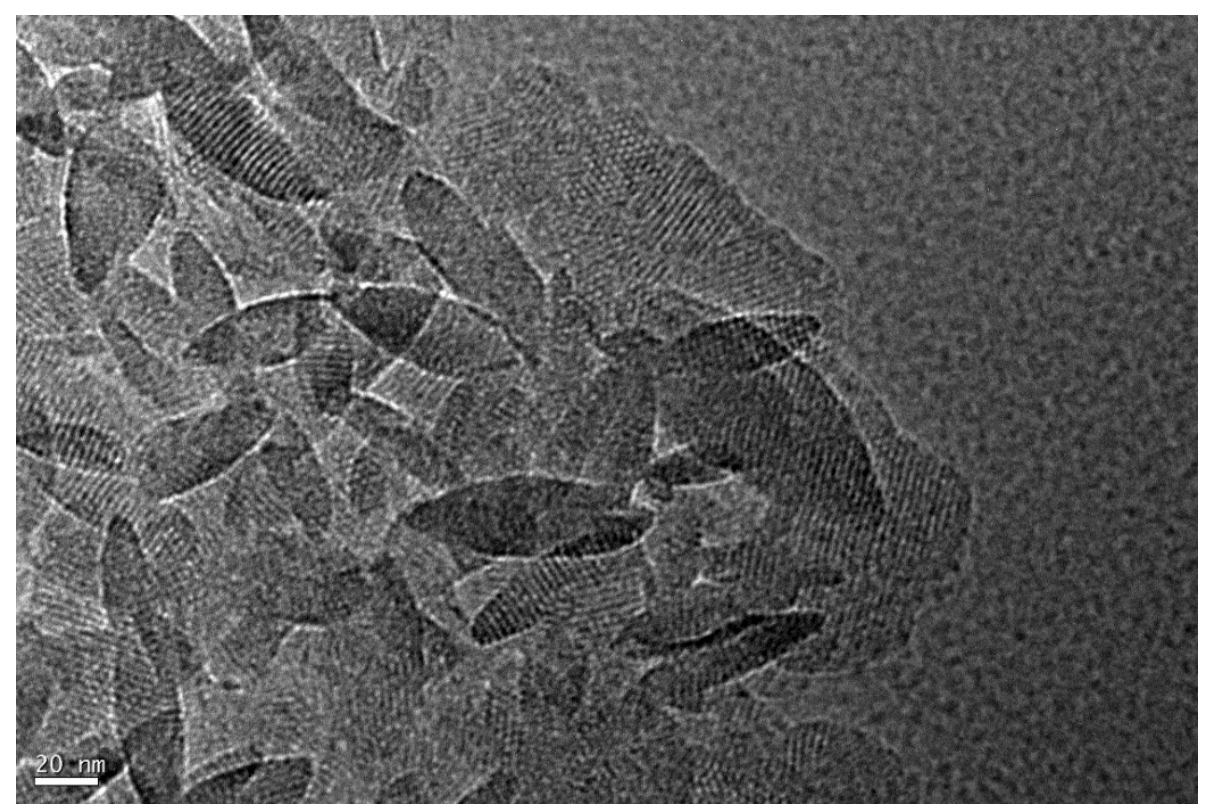

Figure S36. TEM image of LZU-72, showing the ordered channels with the distinct pore size as well. 


\section{Structural modeling of $L Z U-72$}

The structural modeling process of LZU-72 was similar to that of LZU-70. The Pawley refined lattice parameters were $a=b=37.4334( \pm 0.0006) \AA$ and $c=3.9433( \pm 0.0049) \AA . R_{\mathrm{wp}}$ and $R_{\mathrm{p}}$ values converged to $6.73 \%$ and $4.86 \%$, respectively. Comparison of the observed and the simulated PXRD patterns (Figure S37) suggested that the preferable structure of LZU-72 is the eclipsed arrangement.
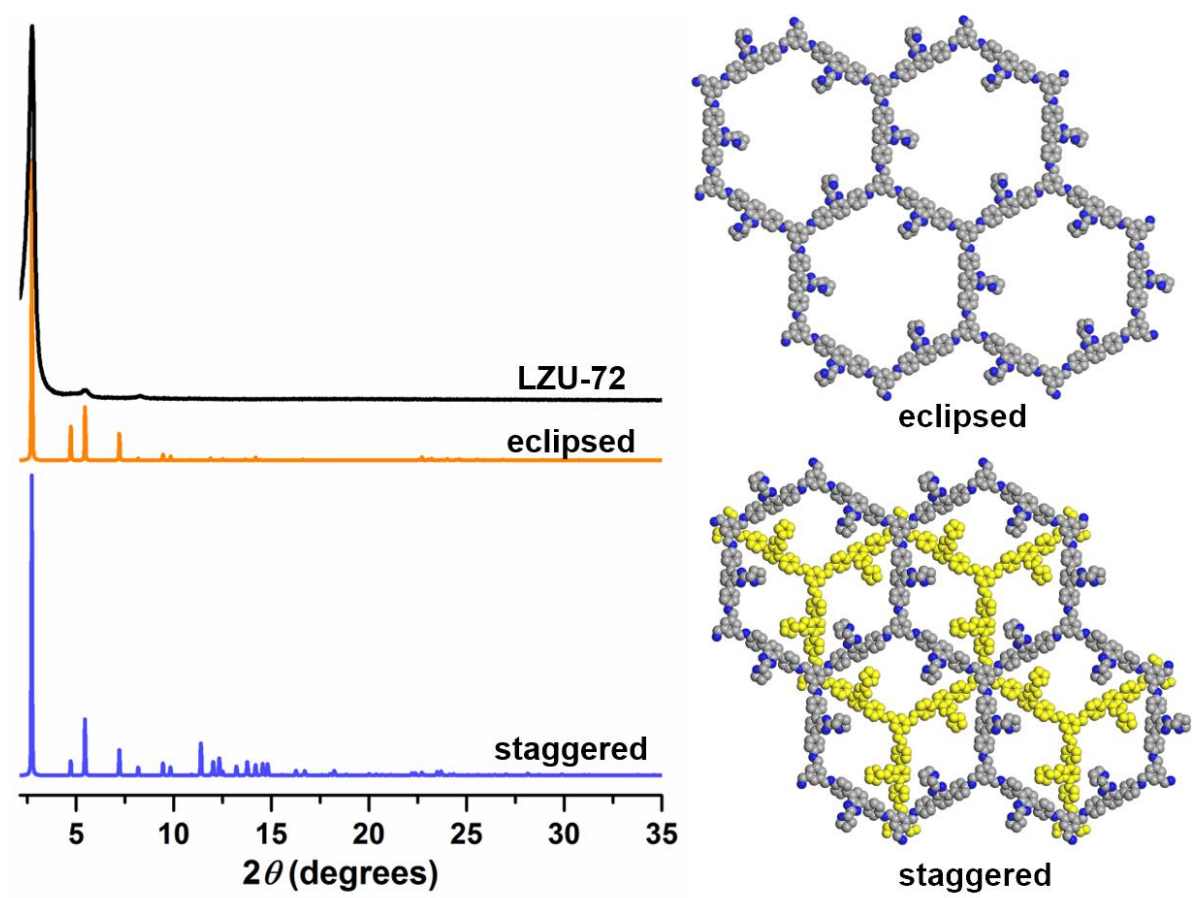

Figure S37. Left: PXRD patterns of LZU-72 observed (black) and calculated with the eclipsed (orange) or staggered (blue) stacking models. Right: Graphic views of eclipsed (top) or staggered (bottom) models. Comparison of the observed and the simulated PXRD patterns suggested that the preferable structure of LZU-72 is the eclipsed arrangement. 
Table S2. Fractional atomic coordinates for the unit cell of LZU-72.

\begin{tabular}{|c|c|c|c|c|c|c|c|}
\hline \multicolumn{8}{|c|}{ LZU-72: Space group symmetry P3 } \\
\hline \multicolumn{8}{|c|}{$a=b=37.4334 \AA, c=3.9433 \AA$} \\
\hline \multicolumn{8}{|c|}{$\alpha=\beta=90^{\circ}, \gamma=120^{\circ}$} \\
\hline Atom & $x(\AA)$ & $y(\AA)$ & $z(\AA)$ & Atom & $x(\AA)$ & y $(\AA)$ & $z(\AA)$ \\
\hline C1 & 1.31216 & -0.87177 & -0.27014 & C30 & 1.57946 & -0.69595 & 0.07895 \\
\hline $\mathrm{C} 2$ & 1.35516 & -0.85227 & -0.21966 & $\mathrm{C} 31$ & 1.04292 & -0.98493 & -0.33913 \\
\hline C3 & 1.37727 & -0.81186 & -0.08728 & C32 & 1.62407 & -0.68136 & 0.09473 \\
\hline $\mathrm{C} 4$ & 1.35454 & -0.79245 & -0.011 & $\mathrm{C} 33$ & 1.02753 & -0.95753 & -0.33986 \\
\hline C5 & 1.31295 & -0.81121 & -0.06199 & $\mathrm{C} 34$ & 1.65221 & -0.63885 & 0.09565 \\
\hline C6 & 1.29013 & -0.85137 & -0.18964 & $\mathrm{H} 35$ & 1.29626 & -0.90264 & -0.37471 \\
\hline $\mathrm{C} 7$ & 1.24469 & -0.87225 & -0.22941 & $\mathrm{H} 36$ & 1.37112 & -0.86865 & -0.28751 \\
\hline $\mathrm{C} 8$ & 1.42247 & -0.79122 & -0.03713 & H37 & 1.24378 & -0.81924 & -0.44036 \\
\hline C9 & 1.22563 & -0.85104 & -0.36057 & $\mathrm{H} 38$ & 1.16866 & -0.85391 & -0.49377 \\
\hline C10 & 1.18278 & -0.87079 & -0.39253 & H39 & 1.15903 & -0.9647 & -0.07183 \\
\hline C11 & 1.15813 & -0.91207 & -0.29642 & $\mathrm{H} 40$ & 1.2337 & -0.9304 & -0.02048 \\
\hline C12 & 1.17705 & -0.93334 & -0.16181 & $\mathrm{H} 41$ & 1.42132 & \begin{tabular}{|l|}
-0.84409 \\
\end{tabular} & 0.1973 \\
\hline $\mathrm{C} 13$ & 1.21993 & -0.91361 & -0.13046 & $\mathrm{H} 42$ & 1.49645 & -0.81059 & 0.26365 \\
\hline C14 & 1.44041 & -0.81265 & 0.11051 & $\mathrm{H} 43$ & 1.50971 & \begin{tabular}{|l|}
-0.70061 \\
\end{tabular} & -0.20745 \\
\hline $\mathrm{C} 15$ & 1.48315 & -0.79359 & 0.14942 & $\mathrm{H} 44$ & 1.43526 & -0.73382 & -0.27323 \\
\hline $\mathrm{C} 16$ & 1.50873 & -0.75284 & 0.04352 & $\mathrm{H} 45$ & 1.39703 & -0.73206 & 0.23203 \\
\hline C17 & 1.49089 & -0.73146 & -0.10882 & $\mathrm{H} 46$ & 1.33249 & -0.71542 & 0.58317 \\
\hline C18 & 1.44815 & -0.75055 & -0.14824 & $\mathrm{H} 47$ & 1.38739 & -0.66496 & 0.33666 \\
\hline N19 & 1.11414 & -0.93049 & -0.32363 & $\mathrm{H} 48$ & 1.35176 & -0.6373 & -0.13448 \\
\hline $\mathrm{N} 20$ & 1.55257 & -0.73513 & 0.07722 & $\mathrm{H} 49$ & 1.36465 & -0.62074 & 0.29534 \\
\hline $\mathrm{N} 21$ & 1.36787 & -0.75354 & 0.14163 & $\mathrm{H} 50$ & 1.28299 & -0.66452 & 0.0339 \\
\hline $\mathrm{C} 22$ & 1.33043 & -0.75206 & 0.16468 & $\mathrm{H} 51$ & 1.29689 & -0.66099 & 0.47241 \\
\hline $\mathrm{N} 23$ & 1.29805 & -0.78501 & 0.0514 & $\mathrm{H} 52$ & 1.27697 & -0.72928 & -0.02719 \\
\hline $\mathrm{C} 24$ & 1.32896 & -0.71545 & 0.3052 & $\mathrm{H} 53$ & 1.2645 & -0.7333 & 0.41552 \\
\hline N25 & 1.36265 & -0.67715 & 0.16575 & $\mathrm{H} 54$ & 1.09792 & -0.99215 & -0.32177 \\
\hline $\mathrm{C} 26$ & 1.34723 & -0.64826 & 0.13064 & $\mathrm{H} 55$ & 1.56961 & -0.67327 & 0.06883 \\
\hline $\mathrm{C} 27$ & 1.3015 & -0.67075 & 0.21926 & $\mathrm{H} 56$ & 1.04865 & -0.92454 & -0.3365 \\
\hline $\mathrm{C} 28$ & 1.28897 & -0.71579 & 0.22561 & $\mathrm{H} 57$ & 1.64075 & -0.6174 & 0.09133 \\
\hline $\mathrm{C} 29$ & 1.08766 & -0.96978 & -0.32678 & & & & \\
\hline
\end{tabular}




\section{Synthesis, Characterization, and Structural Modeling of LZU-76-Boc and LZU-76}

\section{Synthesis of LZU-76-Boc and LZU-76}

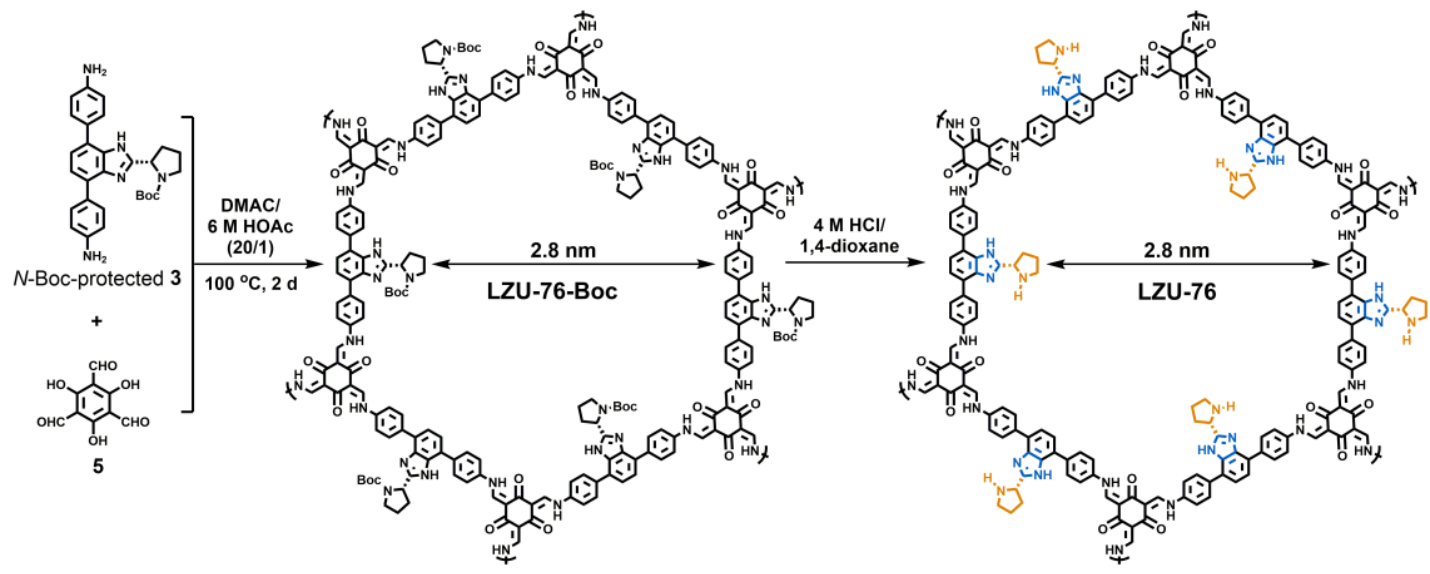

Scheme S3. Synthesis of LZU-76-Boc and LZU-76.

LZU-76-Boc. Triformylphloroglucinol (5) $(10.5 \mathrm{mg}, 0.050 \mathrm{mmol})$ and the $\mathrm{N}$-Boc-protected $3(35.2$ $\mathrm{mg}, 0.075 \mathrm{mmol}$ ) were weighed into a $10 \mathrm{~mL}$ glass ampoule. To the mixture was added $1.0 \mathrm{~mL}$ of $\mathrm{N}, \mathrm{N}$-dimethylacetamide (DMAC), and the resulting suspension was sonicated briefly. Then $50 \mu \mathrm{L}$ of $6 \mathrm{M}$ aqueous acetic acid was added to the mixture. The glass ampoule was frozen in a liquid nitrogen bath, evacuated to an internal pressure of 0 mbar and flame sealed. After warming to room temperature, the sealed ampoule was placed in an oven at $100^{\circ} \mathrm{C}$ and left undisturbed for 2 days, yielding a brick-red solid. The ampoule was opened when the mixture was still warm (ca. $40^{\circ} \mathrm{C}$ ) and the solid was transferred into a vial, separated by centrifugation, washed with DMAC $(2 \times 6$ $\mathrm{mL}), \mathrm{H}_{2} \mathrm{O}(1 \times 6 \mathrm{~mL})$, THF $(2 \times 6 \mathrm{~mL})$, and acetone $(2 \times 6 \mathrm{~mL})$. The resulting powder was dried at room temperature, and then at $90^{\circ} \mathrm{C}$ for $12 \mathrm{~h}$ to afford LZU-76-Boc as a brick-red powder $(37.6 \mathrm{mg}$, $87 \%$ yield). Further purification of LZU-76-Boc was carried out by Soxhlet extraction in THF for 24 h. Anal. Cald for $\left(\mathrm{C}_{34} \mathrm{H}_{31} \mathrm{~N}_{5} \mathrm{O}_{4}\right)_{n}$ : C 71.20; H 5.41; N 12.22. Found: C 68.46; H 5.32; N 10.87. IR (powder, $\mathrm{cm}^{-1}$ ) 3437, 2969, 2876, 1676, 1620, 1595, 1532, 1450, 1284, 1253, 805.

LZU-76. To a $10 \mathrm{~mL}$ tube were added LZU-76-Boc $(30 \mathrm{mg})$ and $1.0 \mathrm{~mL}$ of $4 \mathrm{M} \mathrm{HCl} / 1$,4-dioxane. The resulting suspension was stirred at room temperature for $2 \mathrm{~h}$. The solid was then transferred into a vial, and washed with THF $(1 \times 6 \mathrm{~mL}), \mathrm{MeOH}$ (with $2 \%$ of $\left.\mathrm{Et}_{3} \mathrm{~N}\right)(2 \times 6 \mathrm{~mL}), \mathrm{H}_{2} \mathrm{O}(1 \times 6 \mathrm{~mL}), \mathrm{THF}(1$ $\times 6 \mathrm{~mL})$, and $\mathrm{Et}_{2} \mathrm{O}(1 \times 6 \mathrm{~mL})$ in sequence. The resulting powder was dried at room temperature, and then at $90^{\circ} \mathrm{C}$ for $12 \mathrm{~h}$ to afford LZU-76 as a brick-red powder $(23.5 \mathrm{mg}, 95 \%$ yield). Further purification of LZU-76 was carried out by Soxhlet extraction in THF for $24 \mathrm{~h}$. Anal. Cald for $\left(\mathrm{C}_{29} \mathrm{H}_{23} \mathrm{~N}_{5} \mathrm{O}_{2}\right)_{n}$ : C 73.57; $\mathrm{H} 4.86$; $\left.\mathrm{N} \mathrm{14.80.} \mathrm{Found:} \mathrm{C} \mathrm{70.37;} \mathrm{H} \mathrm{4.74;} \mathrm{N} \mathrm{13.28.} \mathrm{IR} \mathrm{(powder,} \mathrm{cm}^{-1}\right)$ 3436, 1618, 1592, 1570, 1531, 1450, 1286, 1256, 807.

Amorphous LZU-76. The synthetic conditions of Amorphous LZU-76 were similar to that of crystalline LZU-76, except that 1-butyl-3-methylimidazolium tetrafluoroborate ([BMIM]BF 4$)$ was used as the solvent instead of DMAC.

The molecular connectivity, crystallinity, thermal stability, porosity, and morphology of LZU-76-Boc and LZU-76 were investigated in details, and the results are shown in the following. 


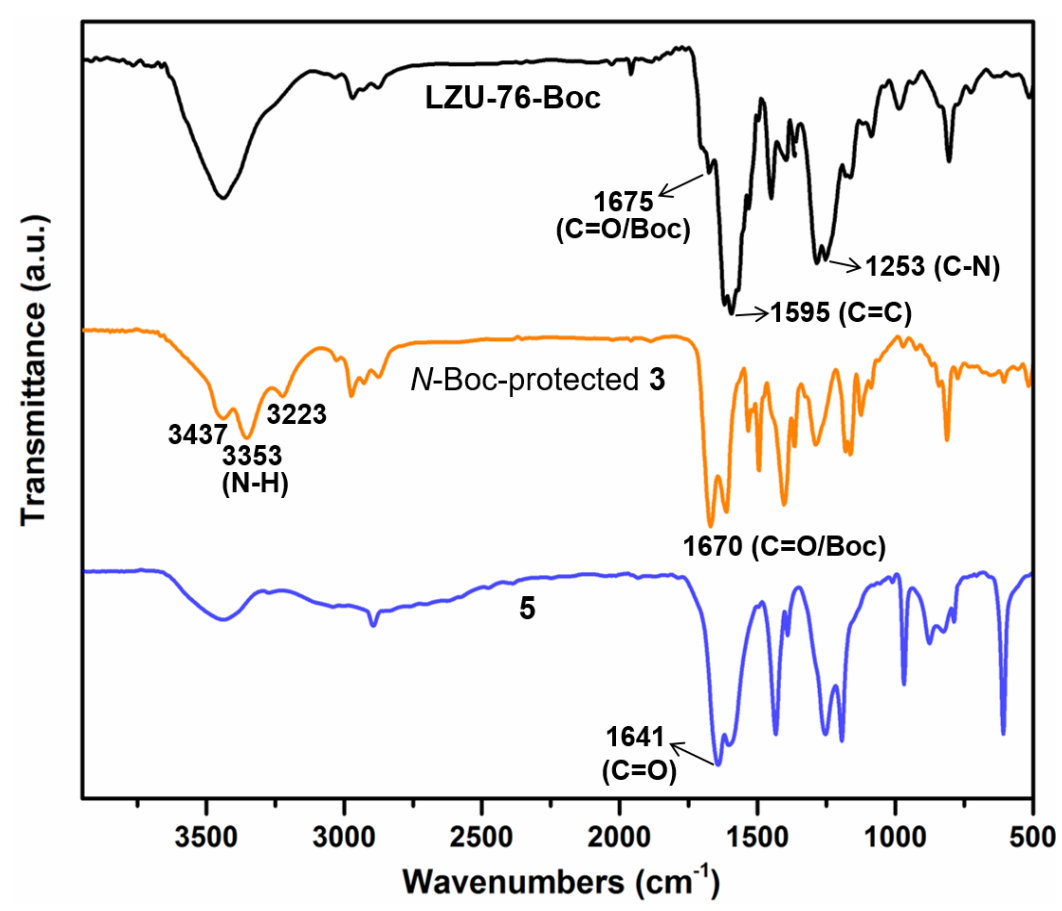

Figure S38. FT-IR spectra of LZU-76-Boc (black), N-Boc-protected $\mathbf{3}$ (orange), and monomer $\mathbf{5}$ (blue). The FT-IR spectrum of LZU-76-Boc (black) shows a strong $-\mathrm{C}-\mathrm{N}-$ stretch at $1253 \mathrm{~cm}^{-1}$ and a $-C=C-$ stretch at $1595 \mathrm{~cm}^{-1}$, indicating the successful formation of the $\beta$-ketoenamine linkages.

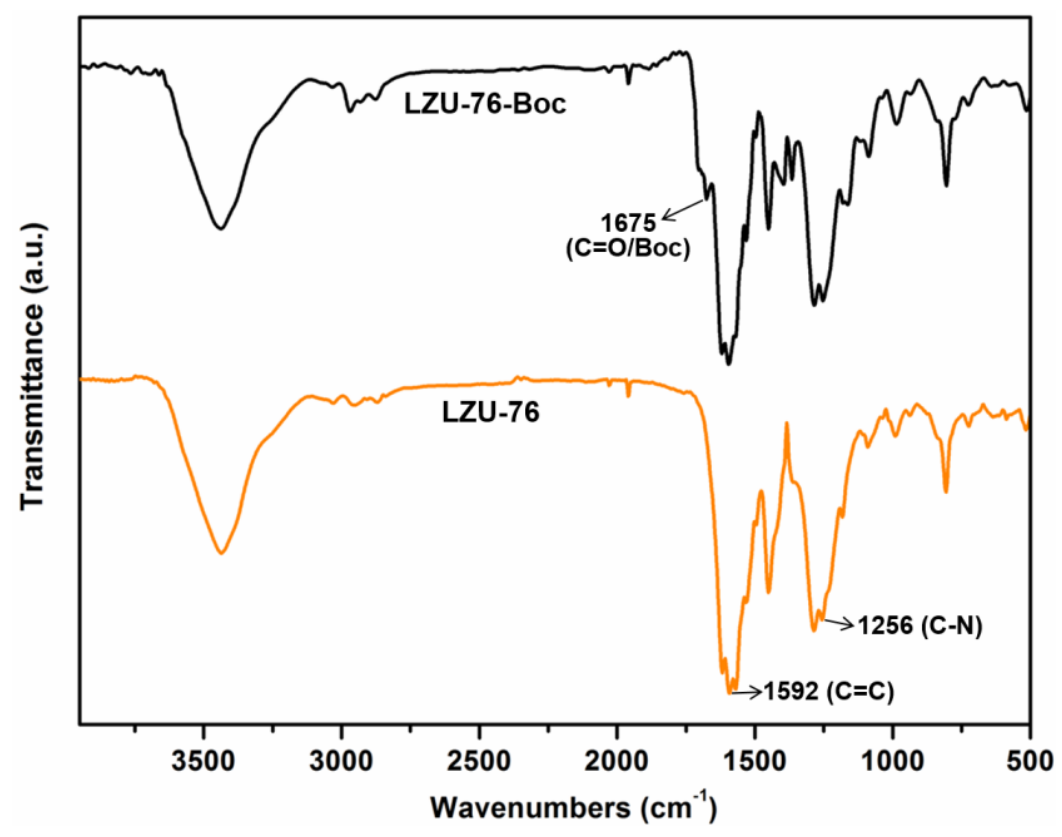

Figure S39. FT-IR spectra of LZU-76-Boc (black) and LZU-76 (orange). The disappearance of the stretch at $1675 \mathrm{~cm}^{-1}(\mathrm{C}=\mathrm{O})$ in the FT-IR spectrum of LZU-76 (orange) indicated the successful deprotection of the Boc groups. 


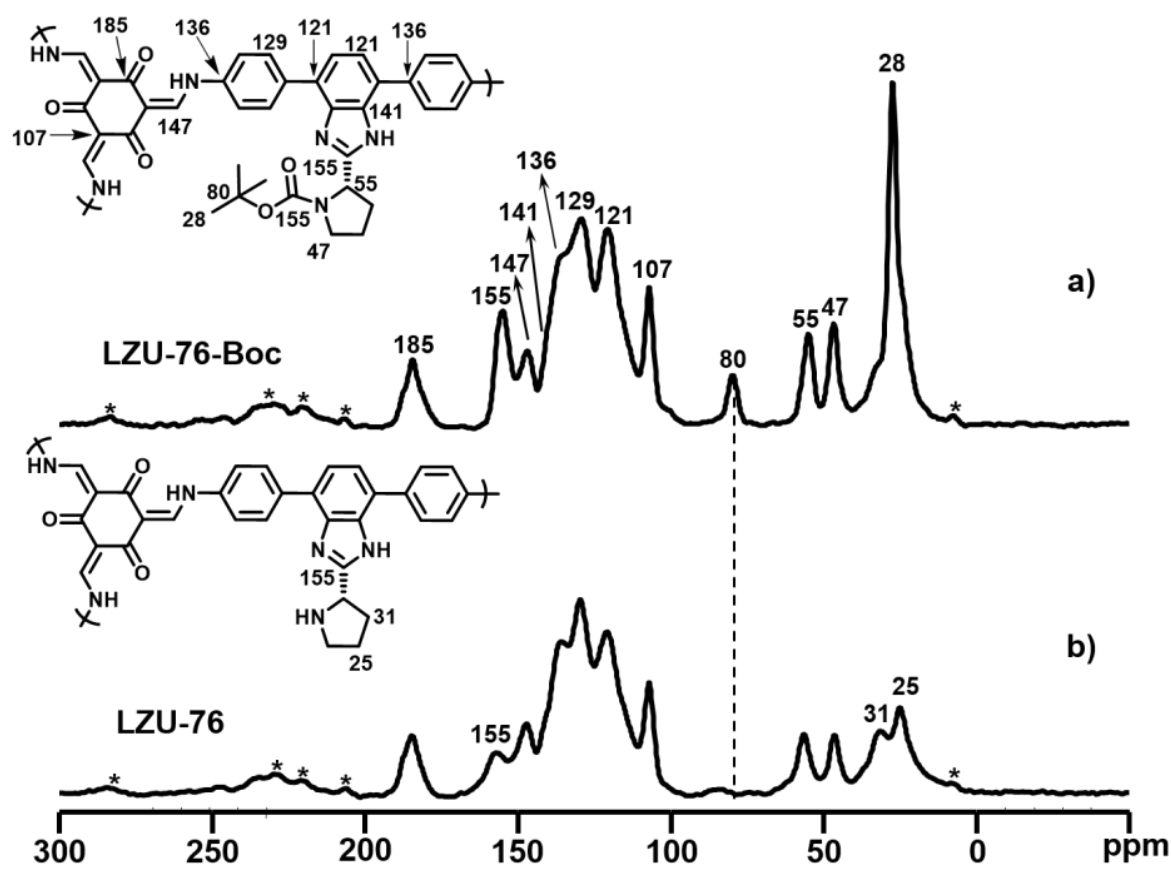

Figure S40. ${ }^{13} \mathrm{C}$ CP/MAS NMR spectra of LZU-76-Boc (a) and LZU-76 (b). The asterisks denote spinning sidebands. The assignments of ${ }^{13} \mathrm{C}$ chemical shifts are indicated in the chemical structures. The ${ }^{13} \mathrm{C}$ CP/MAS NMR spectrum of LZU-76-Boc (a) exhibited the signals at $\delta=107$ and $185 \mathrm{ppm}$, which are assigned to the carbon atoms of the $\alpha$-enamine and the carbonyl groups, respectively. The appearance of the signals at $\delta=28,47,55,80$, and 155 ppm confirmed that $N$-Boc-protected 3

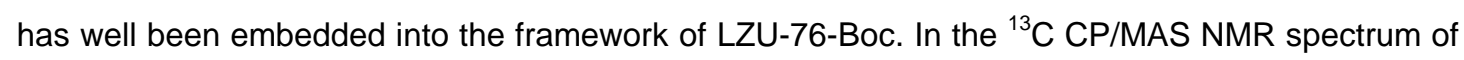
LZU-76 (b), the signal at $\delta=80 \mathrm{ppm}$, which corresponds to the quaternary carbon of the tert-butyl on the Boc groups, disppeared, indicating the successful deprotection of the Boc groups. 


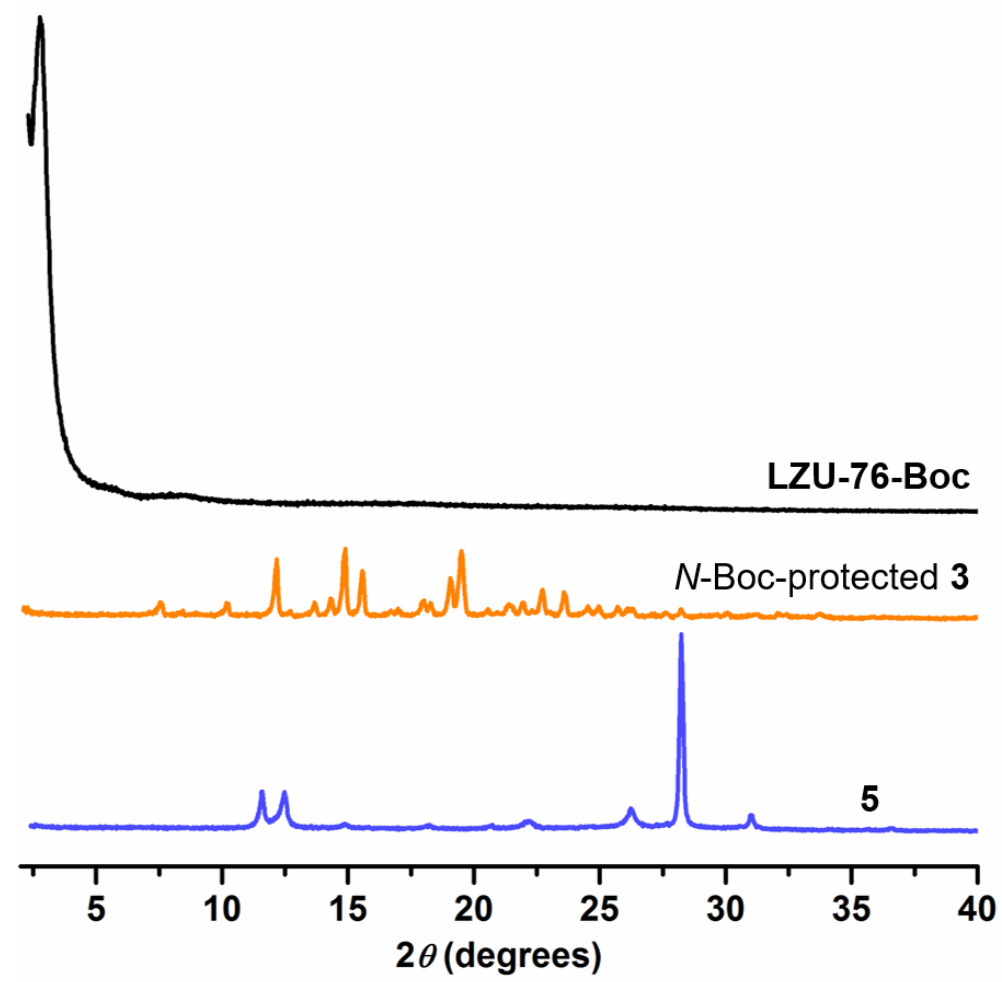

Figure S41. PXRD patterns of LZU-76-Boc (black), N-Boc-protected 3 (orange), and monomer 5 (blue). No diffraction peaks from $\mathbf{N}$-Boc-protected $\mathbf{3}$ or monomer $\mathbf{5}$ could be observed in the PXRD pattern of LZU-76-Boc (black), indicating the sole formation of the crystalline LZU-76-Boc material.

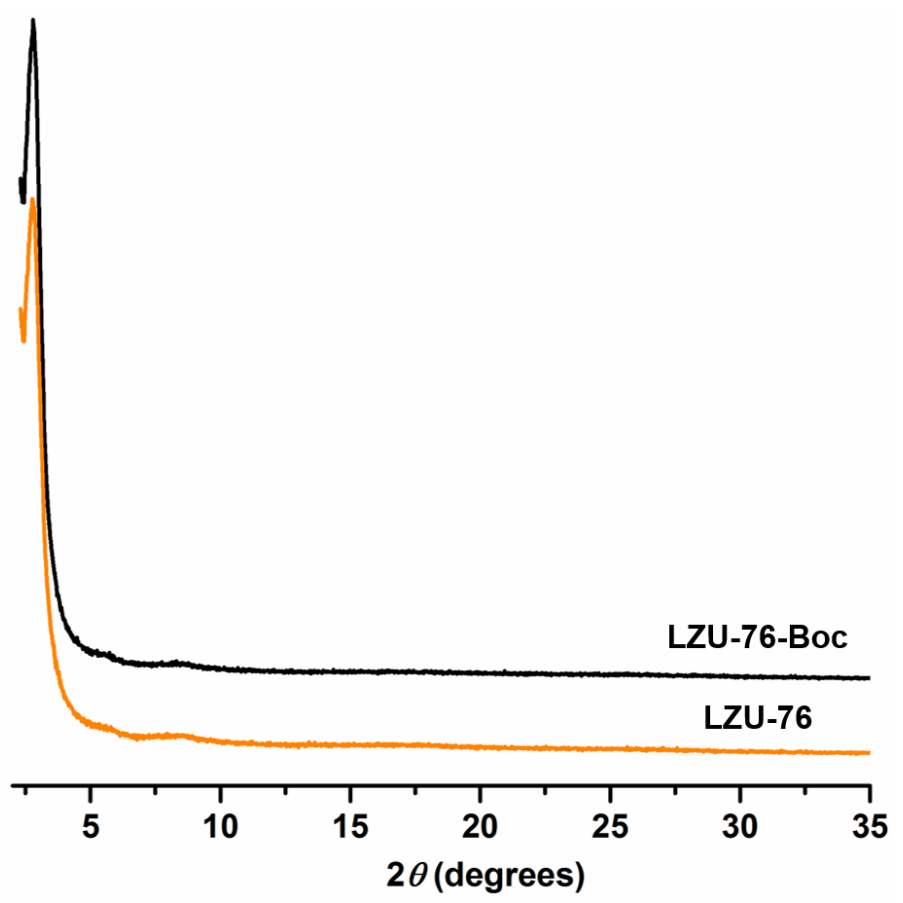

Figure S42. PXRD patterns of LZU-76-Boc (black) and LZU-76 (orange). The PXRD pattern of LZU-76 (orange) is almost identical to that of LZU-76-Boc (black), indicating that the crystalline structure of LZU-76-Boc was well maintained during the deprotection process. 


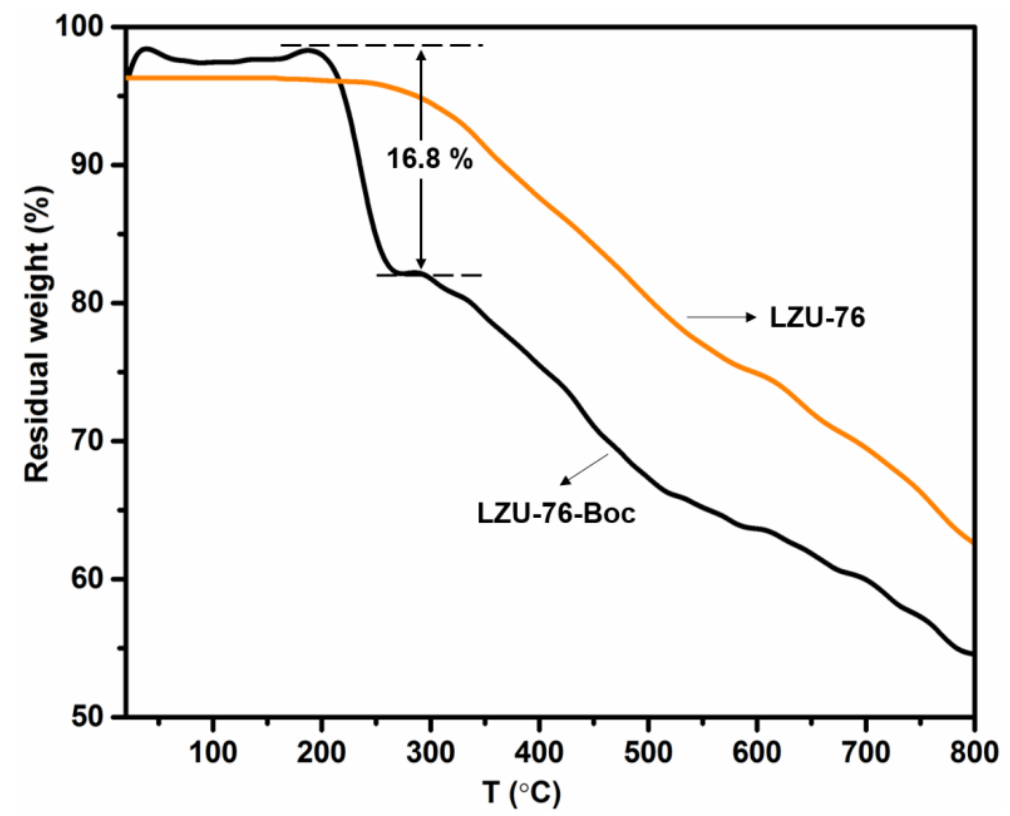

Figure S43. TGA curves of LZU-76-Boc (black) and LZU-76 (orange). The TGA curve of LZU-76-Boc (black) showed a significant weight loss (16.8\%) in the region of $186-274{ }^{\circ} \mathrm{C}$, corresponding to the loss of the Boc groups (theoretical value of $17.4 \%$ ).

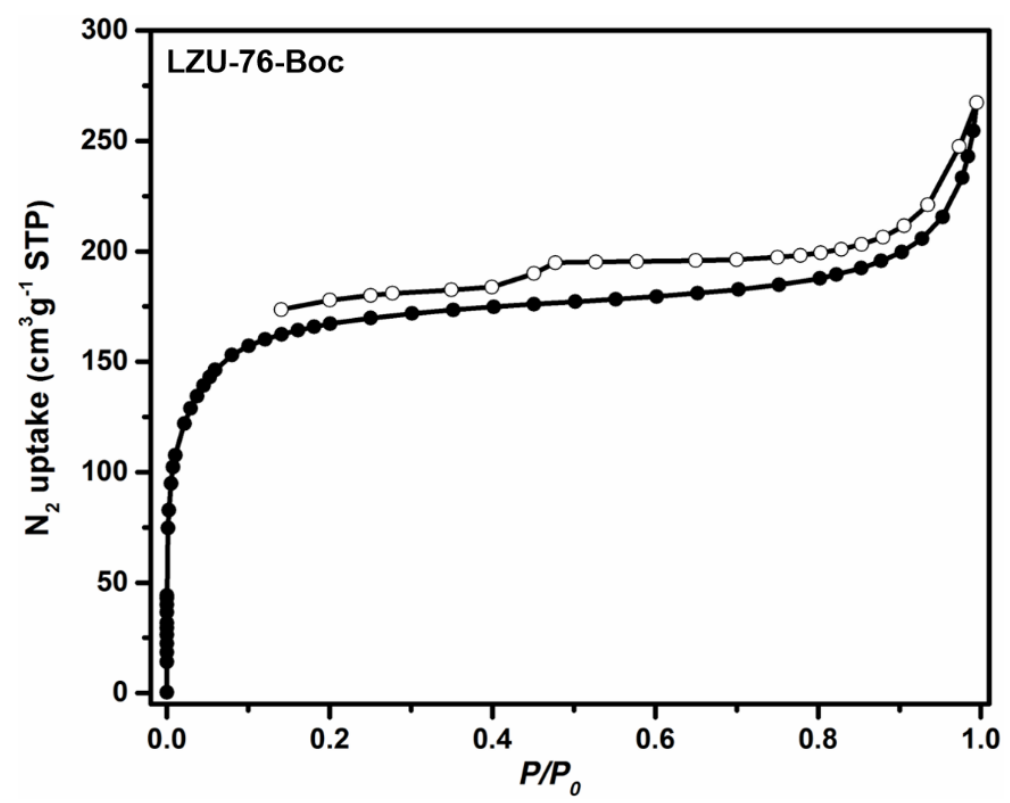

Figure S44. Nitrogen adsorption (filled symbols) and desorption (empty symbols) isotherms of LZU-76-Boc. 


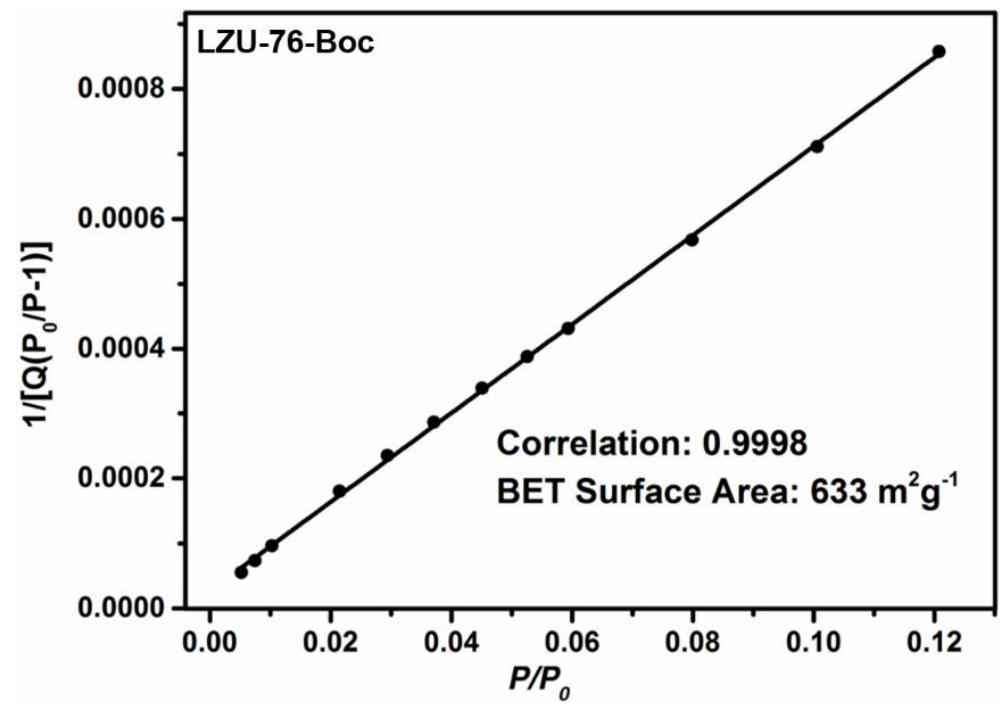

Figure S45. BET surface area plot for LZU-76-Boc calculated from the $\mathrm{N}_{2}$ absorption isotherm.

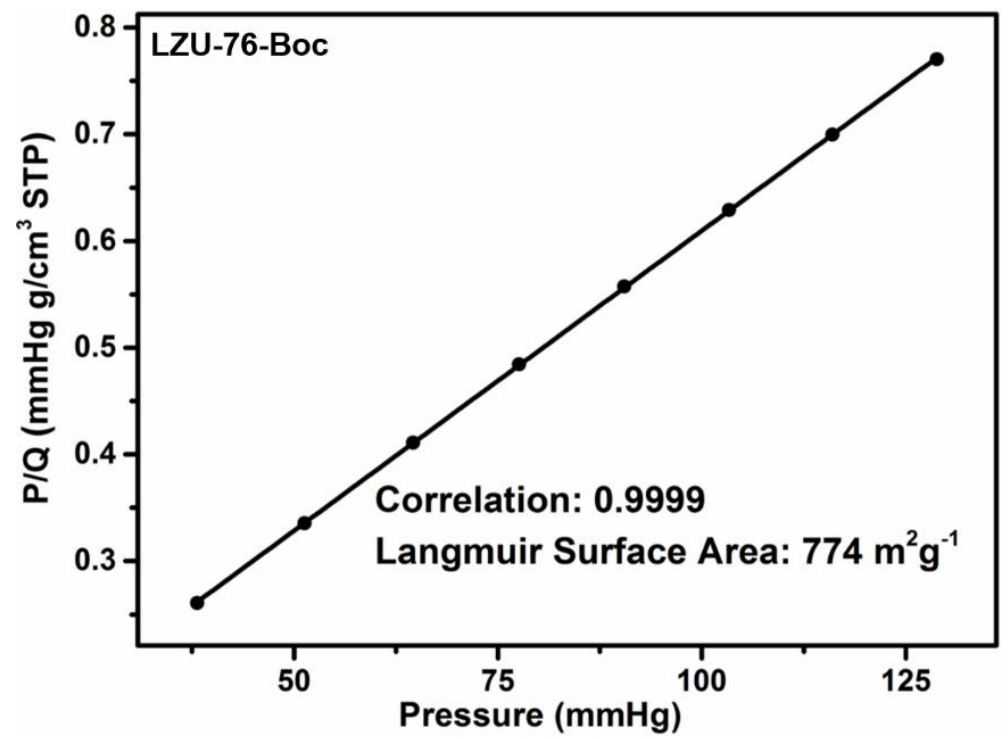

Figure S46. Langmuir surface area plot for LZU-76-Boc calculated from the $\mathrm{N}_{2}$ absorption isotherm. 


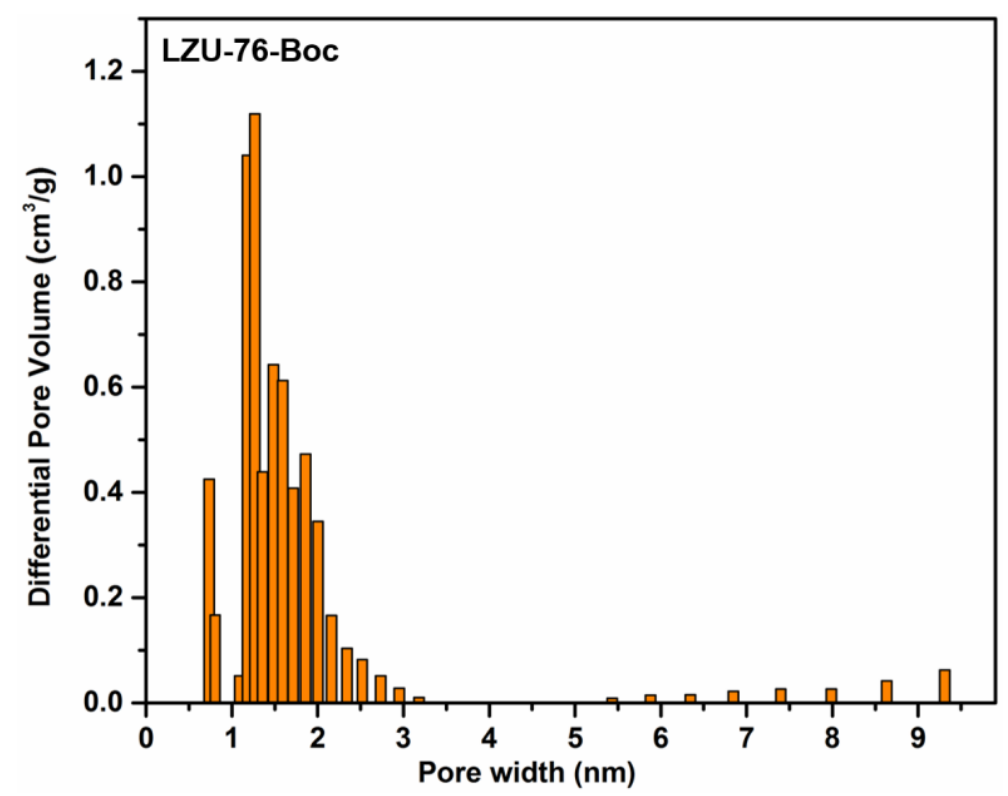

Figure S47. Pore size distribution of LZU-76-Boc calculated by NLDFT (slit pores model).

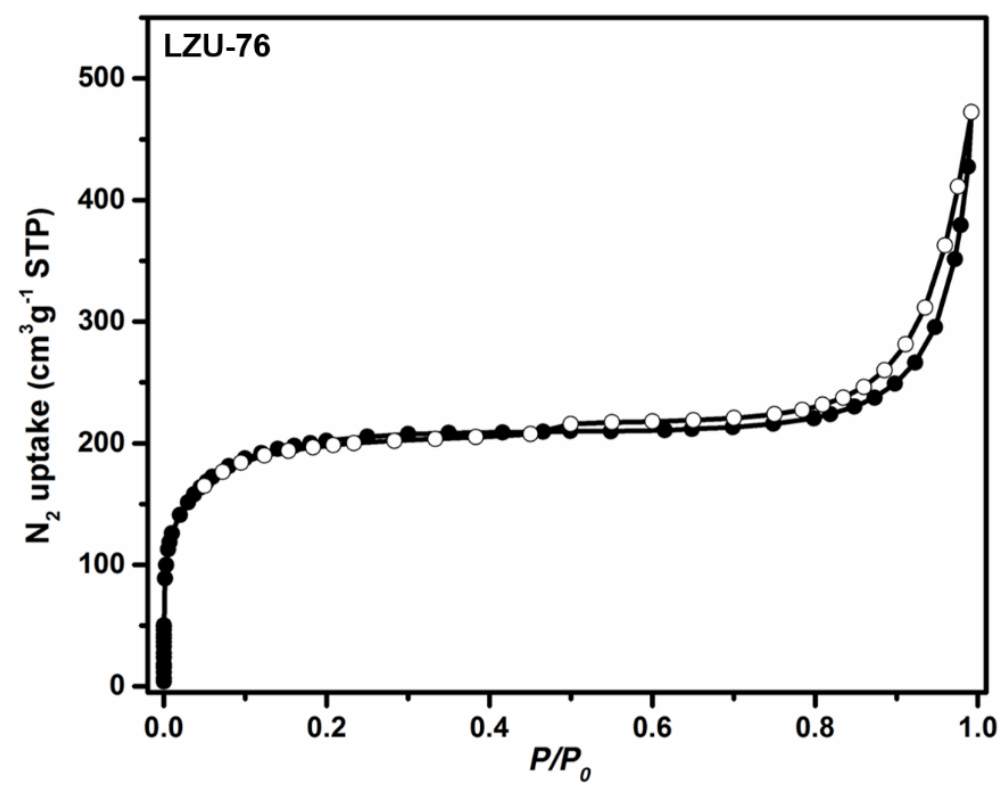

Figure S48. Nitrogen adsorption (filled symbols) and desorption (empty symbols) isotherms of LZU-76. 


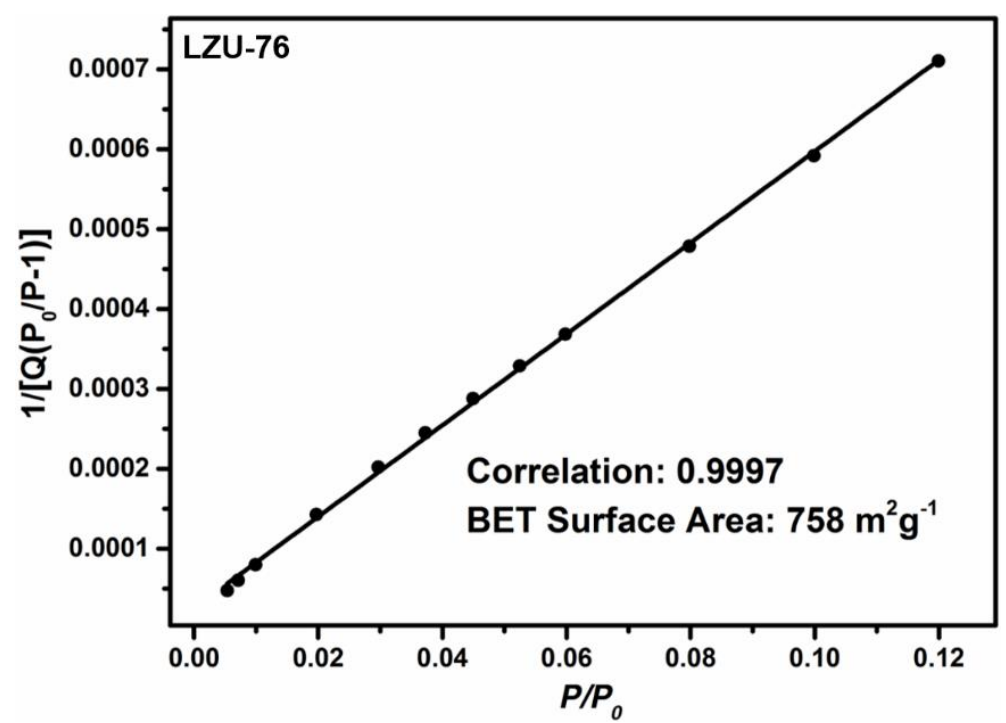

Figure S49. BET surface area plot for LZU-76 calculated from the $\mathrm{N}_{2}$ absorption isotherm.

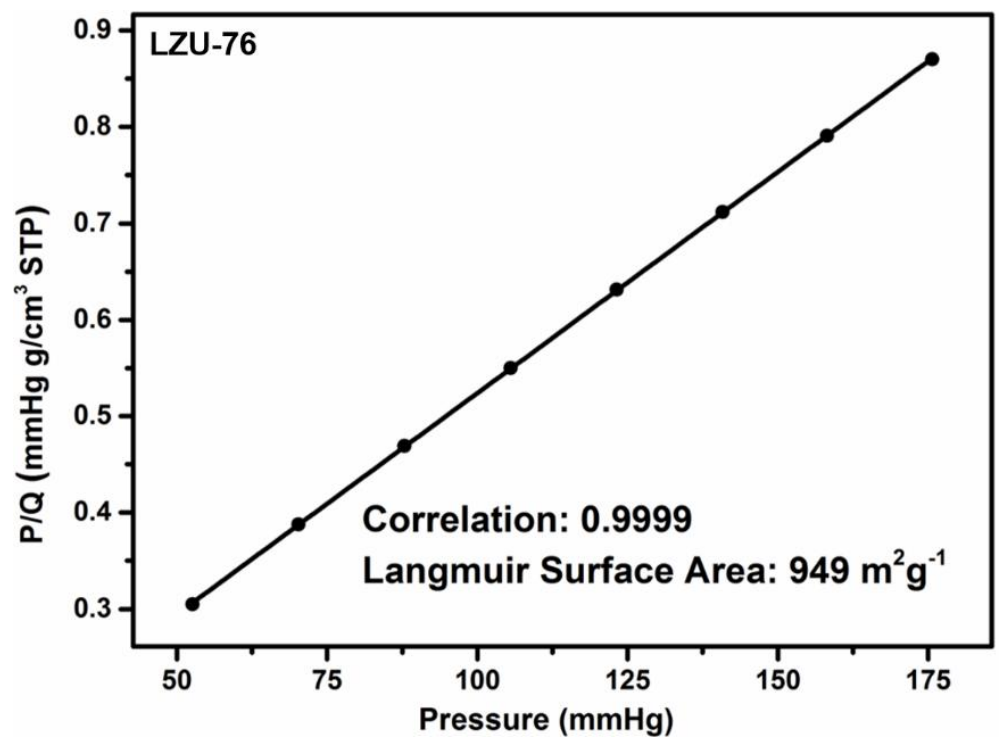

Figure S50. Langmuir surface area plot for LZU-76 calculated from the $\mathrm{N}_{2}$ absorption isotherm. 


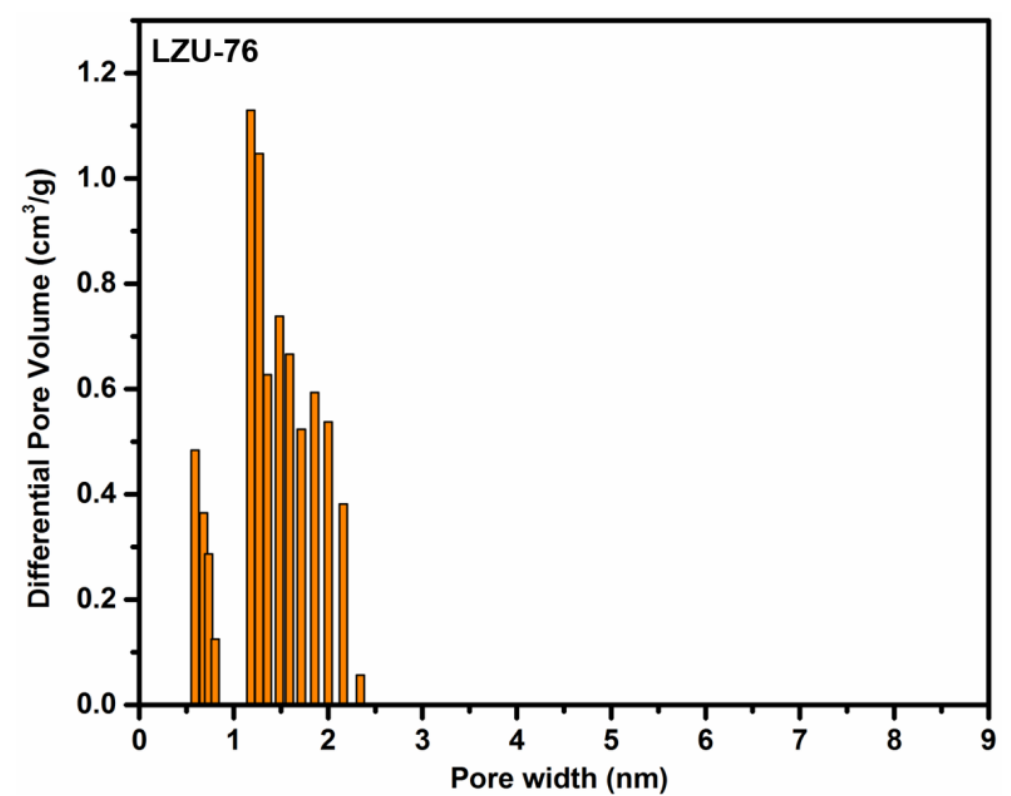

Figure S51. Pore size distribution of LZU-76 calculated by NLDFT (slit pores model). 
Simulations of the nitrogen isotherm and BET surface area of $L Z U-76$

The process for simulations of the nitrogen isotherm and BET surface area of LZU-76 was similar to that of LZU-70. The obtained results are shown in Figures S52 and S53.

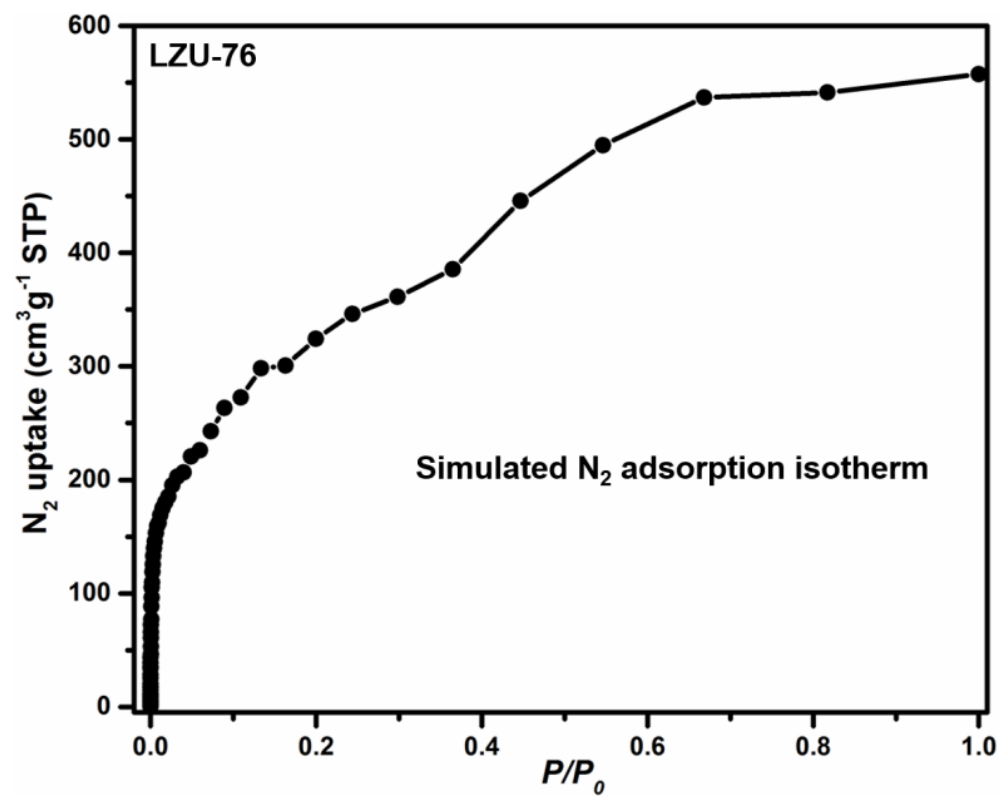

Figure S52. Simulated nitrogen adsorption isotherm of LZU-76.

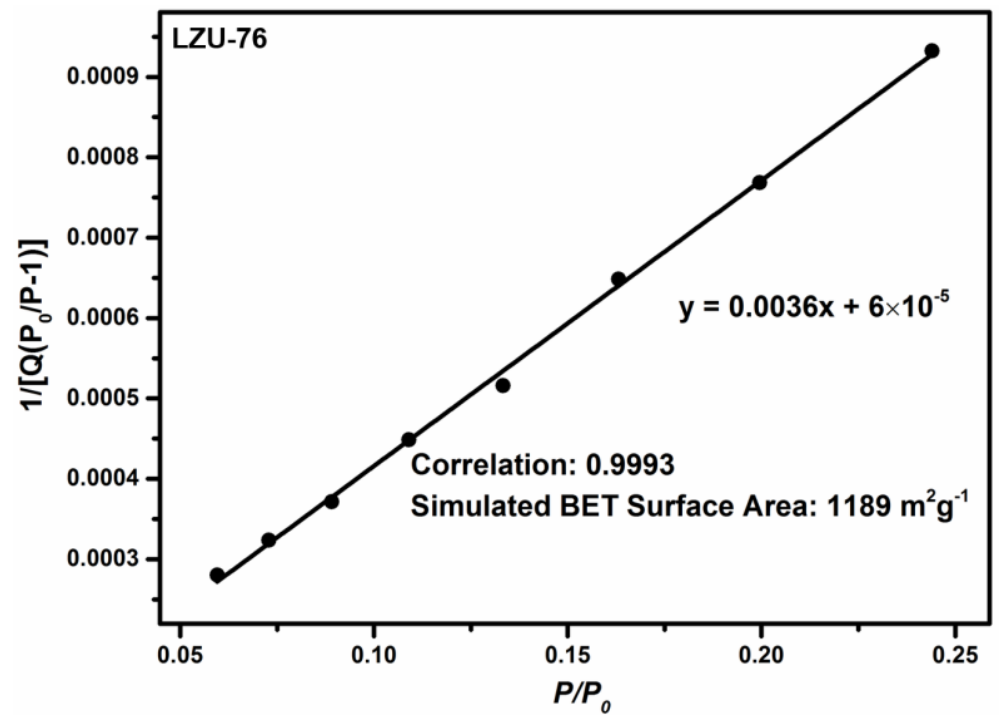

Figure S53. Simulated BET surface area plot for LZU-76. The $V_{\mathrm{m}}=273.2 \mathrm{~cm}^{3} \mathrm{~g}^{-1}(\mathrm{STP})$. 

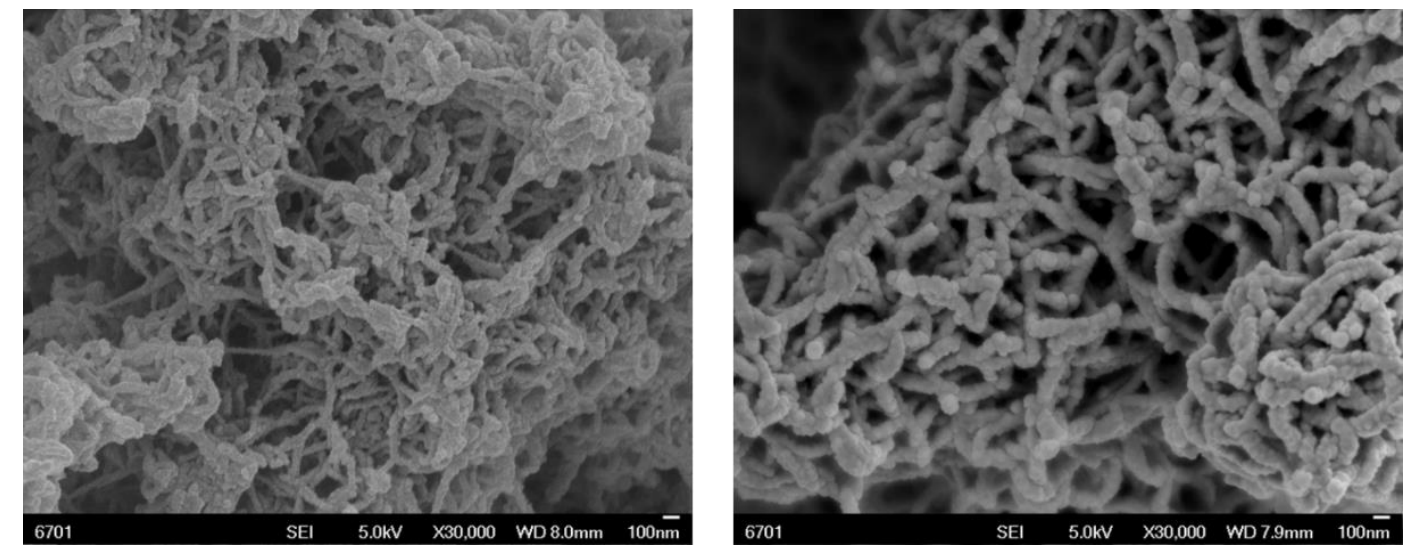

Figure S54. SEM images of LZU-76-Boc (left) and LZU-76 (right). Both COFs were crystallized in a thread-like morphology.
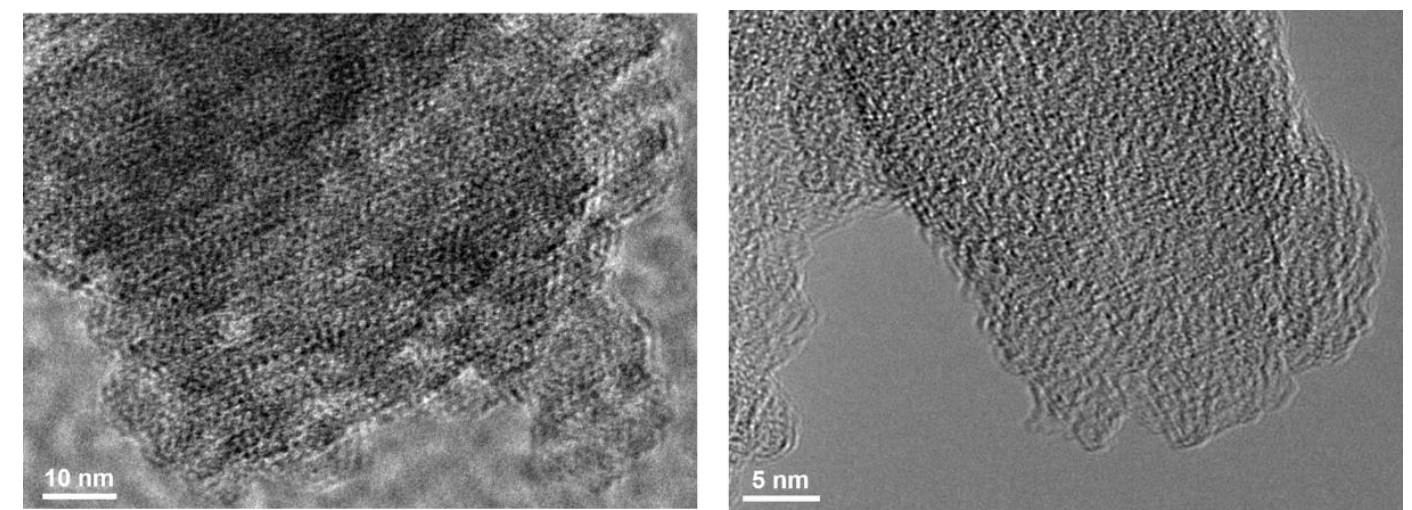

Figure S55. TEM images of LZU-76-Boc (left) and LZU-76 (right). 


\section{Structural modeling of $L Z U-76$}

The structural modeling process of LZU-76 was similar to that of LZU-70. The Pawley refined lattice parameters were $a=b=37.4089( \pm 0.0060) \AA$ and $c=5.0118( \pm 0.0011) \AA . R_{\mathrm{wp}}$ and $R_{\mathrm{p}}$ values converged to $4.59 \%$ and $2.90 \%$, respectively. Comparison of the observed and the simulated PXRD patterns (Figure S56) suggested that the preferable structure of LZU-76 is the eclipsed arrangement.
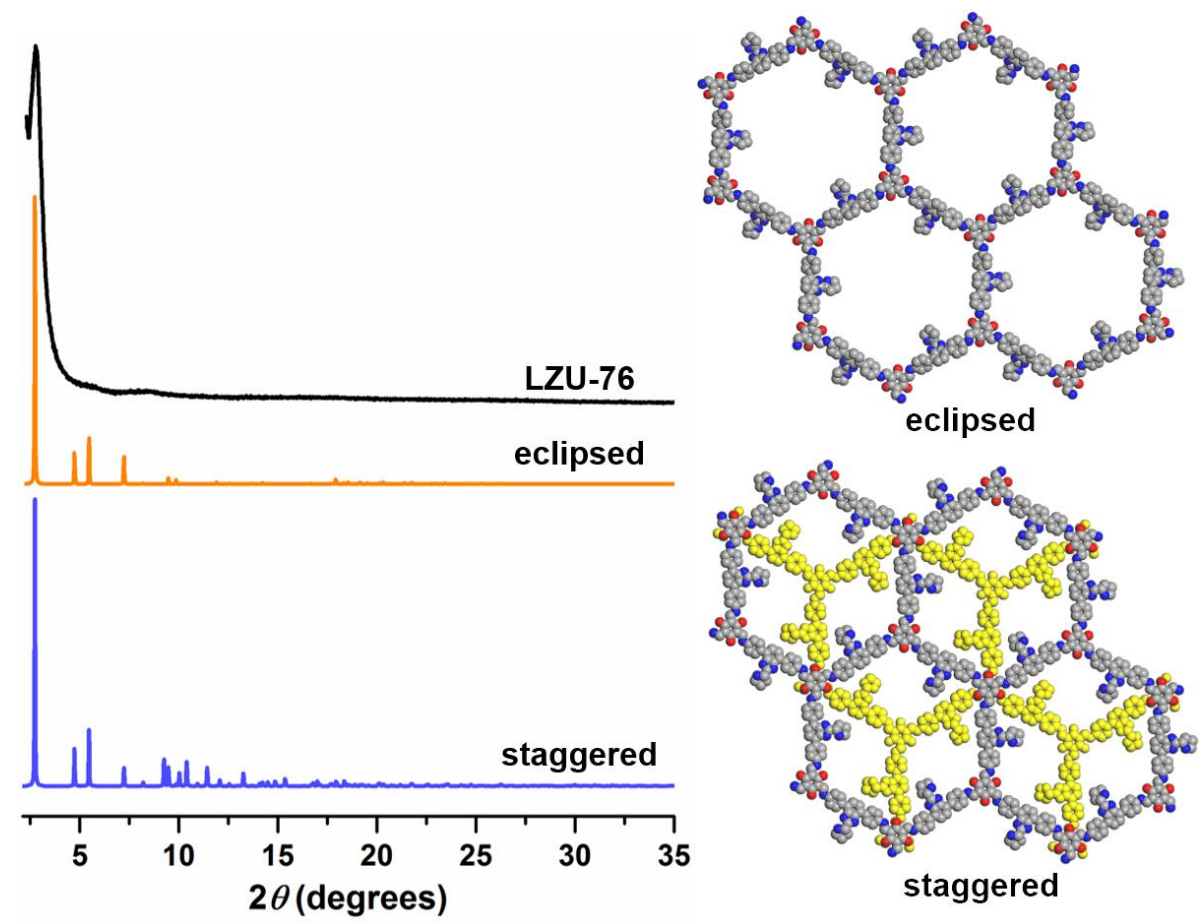

Figure S56. Left: PXRD patterns of LZU-76 observed (black) and calculated with the eclipsed (orange) or staggered (blue) stacking models. Right: Graphic views of eclipsed (top) or staggered (bottom) models. Comparison of the observed and the simulated PXRD patterns suggested that the preferable structure of LZU-76 is the eclipsed arrangement. 
Table S3. Fractional atomic coordinates for the unit cell of LZU-76.

\begin{tabular}{|c|c|c|c|c|c|c|c|}
\hline & & LZL & Space & inc & netry $P 3$ & & \\
\hline & & & $\cdots$ & & $110^{\circ} 1$ & & \\
\hline & & & $\alpha=\beta=$ & , & & & \\
\hline Atom & $x(\AA ̊)$ & y $(\AA ̊)$ & $z(\AA)$ & Atom & $x(\AA)$ & $\mathrm{y}(\AA)$ & $z(\AA)$ \\
\hline C1 & 2.31667 & 0.1362 & -0.3657 & $\mathrm{C} 31$ & 2.04359 & 0.02967 & -0.25727 \\
\hline $\mathrm{C} 2$ & 2.35992 & 0.1606 & -0.33512 & C32 & 2.61898 & 0.30583 & 0.12086 \\
\hline C3 & 2.37691 & 0.19311 & -0.1487 & C33 & 2.01378 & 0.04463 & -0.2248 \\
\hline C4 & 2.34955 & 0.19957 & 0.00467 & C34 & 2.64637 & 0.28804 & 0.15525 \\
\hline C5 & 2.30769 & 0.17566 & -0.02006 & O35 & 2.0263 & 0.08041 & -0.15827 \\
\hline C6 & 2.28945 & 0.14344 & -0.20764 & O36 & 2.63167 & 0.25198 & 0.22258 \\
\hline $\mathrm{C} 7$ & 2.2439 & 0.1184 & -0.24581 & $\mathrm{H} 37$ & 2.3047 & 0.11237 & -0.51747 \\
\hline C8 & 2.4218 & 0.21923 & -0.11665 & $\mathrm{H} 38$ & 2.37999 & 0.15451 & -0.45932 \\
\hline $\mathrm{C9}$ & 2.2189 & 0.13663 & -0.23191 & $\mathrm{H} 39$ & 2.23221 & 0.16936 & -0.19543 \\
\hline C10 & 2.17621 & 0.11302 & -0.27145 & $\mathrm{H} 40$ & 2.15855 & 0.12863 & -0.25892 \\
\hline $\mathrm{C} 11$ & 2.15751 & 0.07057 & -0.33071 & $\mathrm{H} 41$ & 2.16891 & 0.01987 & -0.39163 \\
\hline $\mathrm{C} 12$ & 2.18254 & 0.05249 & -0.34734 & $\mathrm{H} 42$ & 2.24329 & 0.06074 & -0.31334 \\
\hline $\mathrm{C} 13$ & 2.22512 & 0.07597 & -0.3 & $\mathrm{H} 43$ & 2.42758 & 0.17653 & 0.14625 \\
\hline C14 & 2.44367 & 0.20606 & 0.04492 & $\mathrm{H} 44$ & 2.50216 & 0.22066 & 0.2106 \\
\hline C15 & 2.48634 & 0.23118 & 0.079 & $\mathrm{H} 45$ & 2.50151 & 0.31223 & -0.3133 \\
\hline C16 & 2.50791 & 0.26951 & -0.05328 & $\mathrm{H} 46$ & 2.42633 & 0.26866 & -0.36389 \\
\hline $\mathrm{C} 17$ & 2.48567 & 0.28266 & -0.2 & $\mathrm{H} 47$ & 2.38735 & 0.25 & 0.24077 \\
\hline C18 & 2.44293 & 0.25781 & -0.2426 & $\mathrm{H} 48$ & 2.29196 & 0.22891 & 0.6386 \\
\hline N19 & 2.35866 & 0.23075 & 0.19623 & $\mathrm{H} 49$ & 2.35481 & 0.2754 & 0.76448 \\
\hline $\mathrm{C} 20$ & 2.31827 & 0.2223 & 0.27561 & $\mathrm{H} 50$ & 2.36879 & 0.34306 & 0.44262 \\
\hline N21 & 2.28809 & 0.19041 & 0.15709 & $\mathrm{H} 51$ & 2.35161 & 0.33287 & 0.78548 \\
\hline $\mathrm{C} 22$ & 2.3108 & 0.24861 & 0.46938 & $\mathrm{H} 52$ & 2.30232 & 0.33193 & 0.36139 \\
\hline $\mathrm{N} 23$ & 2.34992 & 0.28258 & 0.57076 & $\mathrm{H} 53$ & 2.28217 & 0.30204 & 0.66628 \\
\hline $\mathrm{C} 24$ & 2.34572 & 0.31952 & 0.58058 & $\mathrm{H} 54$ & 2.29654 & 0.27498 & 0.1242 \\
\hline $\mathrm{C} 25$ & 2.30235 & 0.30762 & 0.48946 & $\mathrm{H} 55$ & 2.25361 & 0.24736 & 0.3541 \\
\hline $\mathrm{C} 26$ & 2.28767 & 0.26781 & 0.33811 & $\mathrm{H} 56$ & 2.10348 & 0.0162 & -0.46336 \\
\hline $\mathrm{N} 27$ & 2.11367 & 0.04504 & -0.37493 & $\mathrm{H} 57$ & 2.5649 & 0.32571 & -0.10352 \\
\hline N28 & 2.5519 & 0.29586 & -0.0254 & $\mathrm{H} 58$ & 2.09293 & 0.08953 & -0.32149 \\
\hline C29 & 2.08365 & 0.05714 & -0.31115 & $\mathrm{H} 59$ & 2.56733 & 0.24779 & 0.04093 \\
\hline C30 & 2.5789 & 0.28072 & 0.05505 & & & & \\
\hline
\end{tabular}




\section{Catalytic Activity Test of LZU-76}

\section{Optimization of the reaction conditions of asymmetric aldol reaction}

Table S4. Optimization of the reaction conditions of asymmetric aldol reaction. ${ }^{a}$

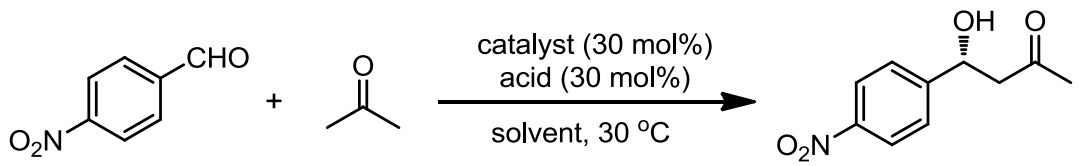

\begin{tabular}{ccccccc}
\hline entry & catalyst & solvent & acid & time $[\mathrm{h}]$ & yield [\% $]^{b}$ & e.r. $^{c}$ \\
\hline 1 & LZU-76 & THF $^{d}$ & TFA & 18 & 35 & $89.7: 10.3$ \\
2 & LZU-76 & CHCl $^{d}$ & TFA & 18 & 42 & $91.9: 8.1$ \\
3 & LZU-76 & EtOH $^{d}$ & TFA & 18 & 28 & $86.0: 14.0$ \\
4 & LZU-76 & Toluene $^{d}$ & TFA & 18 & 33 & $90.8: 9.2$ \\
5 & LZU-76 & Acetone & TFA & 18 & 73 & $94.0: 6.0$ \\
6 & LZU-76 & Acetone & CH ${ }_{3}$ COOH & 4.5 & 85 & $73.5: 26.5$ \\
7 & LZU-76 & Acetone & PhCOOH & 6 & 89 & $78.7: 21.3$ \\
8 & LZU-76 & Acetone & PTSA & 21 & 67 & $66.4: 33.6$ \\
9 & Amorphous LZU-76 & Acetone & TFA & 18 & 39 & $88.2: 11.8$ \\
\hline
\end{tabular}

aGeneral conditions: 4-nitrobenzaldehyde $(30.2 \mathrm{mg}, 0.20 \mathrm{mmol})$, catalyst $(0.06 \mathrm{mmol})$, acid $(0.06$ $\mathrm{mmol})$, and solvent $(1.0 \mathrm{~mL}) .{ }^{b}$ Isolated yield. ${ }^{c}$ Enantiomeric ratios (e.r.) were determined by chiral HPLC. ${ }^{d} 10.0$ equiv of acetone $(2.00 \mathrm{mmol})$ was used. TFA $=$ trifluoroacetic acid, PTSA $=$ p-toluenesulfonic acid. In comparison with that of amorphous LZU-76 (entry 9), the better catalytic performance of crystalline LZU-76 could be attributed to the evenly-distributed active sites which are easily accessable through the regular channels.

\section{Typical procedure for the asymmetric aldol reaction}

LZU-76 (28.4 mg, $0.06 \mathrm{mmol})$ and TFA (4.5 $\mu \mathrm{L}, 0.06 \mathrm{mmol})$ were mixed in acetone $(1.0 \mathrm{~mL})$, and the mixture was stirred for $10 \mathrm{~min}$ at $30^{\circ} \mathrm{C}$. Then 4-nitrobenzaldehyde $(30.2 \mathrm{mg}, 0.20 \mathrm{mmol})$ was added to the mixture. After the reaction (monitored by TLC) was completed, the catalyst was isolated by centrifugation and thoroughly washed with $\mathrm{CH}_{2} \mathrm{Cl}_{2}$ for three times. The combined organic phases were evaporated under vacuum to give the crude products. Purification by silica gel column chromatography (petroleum ether/EtOAc $=3 / 1$ ) afforded the corresponding aldol product. The enantiomeric ratio (e.r.) was determined by HPLC. 
4-hydroxy-4-(4-nitrophenyl)butan-2-one ${ }^{5}$<smiles>CC(=O)CC(O)c1ccc([N+](=O)[O-])cc1</smiles>

${ }^{1} \mathrm{H}$ NMR $\left(400 \mathrm{MHz}, \mathrm{CDCl}_{3}\right) \delta=8.18(\mathrm{~d}, J=8.7 \mathrm{~Hz}, 2 \mathrm{H}), 7.53(\mathrm{~d}, J=8.7 \mathrm{~Hz}, 2 \mathrm{H}), 5.25(\mathrm{~m}, 1 \mathrm{H}), 3.69$ (brs, $1 \mathrm{H}$ ), 2.85-2.84 (m, 2H), 2.21 (s, 3H). ${ }^{13} \mathrm{C}$ NMR $\left(100 \mathrm{MHz}, \mathrm{CDCl}_{3}\right) \delta=208.4,150.1,147.1$, 126.3, 123.6, 68.8, 51.4, 30.6. The enantiomeric ratio (94.0:6.0) was determined by HPLC with Daicel chiral AS-H column at $254 \mathrm{~nm}$ (hexane/ $\mathrm{i}-\mathrm{PrOH}=70 / 30$, flow rate $1.0 \mathrm{~mL} / \mathrm{min}$ ). $\mathrm{t}$ (major) $=$ $12.8 \mathrm{~min}, \mathrm{t}(\operatorname{minor})=16.3 \mathrm{~min}$.

4-hydroxy-4-(2-nitrophenyl)butan-2-one ${ }^{6}$<smiles>CC(=O)CC(O)c1ccccc1[N+](=O)[O-]</smiles>

${ }^{1} \mathrm{H} \mathrm{NMR}\left(400 \mathrm{MHz}, \mathrm{CDCl}_{3}\right) \delta=7.92(\mathrm{dd}, J=8.2,1.0 \mathrm{~Hz}, 1 \mathrm{H}), 7.87(\mathrm{~d}, J=7.3 \mathrm{~Hz}, 1 \mathrm{H}), 7.69-7.59(\mathrm{~m}$, $1 \mathrm{H})$, 7.48-7.36 (m, 1H), 5.66-5.63 (m, 1H), $3.84(\mathrm{brs}, 1 \mathrm{H}), 3.11-3.06(\mathrm{~m}, 1 \mathrm{H}), 2.76-2.69(\mathrm{~m}, 1 \mathrm{H})$, $2.21(\mathrm{~s}, 3 \mathrm{H}) .{ }^{13} \mathrm{C} \mathrm{NMR}\left(100 \mathrm{MHz}, \mathrm{CDCl}_{3}\right) \delta=208.6,147.0,138.4,133.7,128.2,128.1,124.3,65.5$, 51.0, 30.3. The enantiomeric ratio (93.7:6.3) was determined by HPLC with Daicel chiral AS-H column at $254 \mathrm{~nm}$ (hexane $/ i-\mathrm{PrOH}=70 / 30$, flow rate $1.0 \mathrm{~mL} / \mathrm{min}$ ). $\mathrm{t}$ (major) $=11.3 \mathrm{~min}, \mathrm{t}$ (minor) $=$ $8.2 \mathrm{~min}$.

4-(1-hydroxy-3-oxobutyl)benzonitrile ${ }^{5}$<smiles>CC(=O)CC(O)c1ccc(C#N)cc1</smiles>

${ }^{1} \mathrm{H}$ NMR $\left(400 \mathrm{MHz}, \mathrm{CDCl}_{3}\right) \delta=7.63(\mathrm{~d}, J=8.3 \mathrm{~Hz}, 2 \mathrm{H}), 7.47(\mathrm{~d}, J=8.2 \mathrm{~Hz}, 2 \mathrm{H}), 5.20(\mathrm{~m}, 1 \mathrm{H}), 3.64$ $(\mathrm{m}, 1 \mathrm{H}), 2.83(\mathrm{~m}, 2 \mathrm{H}), 2.21$ (s, 3H). ${ }^{13} \mathrm{C}$ NMR $\left(100 \mathrm{MHz}, \mathrm{CDCl}_{3}\right) \delta=208.5,148.0,132.3,126.3$, 118.7, 111.2, 69.0, 51.5, 30.7. The enantiomeric ratio (93.5:6.5) was determined by HPLC with Daicel chiral OD-H column at $240 \mathrm{~nm}$ (hexane $/ \mathrm{i}-\mathrm{PrOH}=90 / 10$, flow rate $1.0 \mathrm{~mL} / \mathrm{min}$ ). $\mathrm{t}$ (major) $=$ $17.1 \mathrm{~min}, \mathrm{t}($ minor $)=19.7 \mathrm{~min}$.

4-(4-bromophenyl)-4-hydroxybutan-2-one ${ }^{5}$<smiles>CC(=O)CC(O)c1ccc(Br)cc1</smiles>

${ }^{1} \mathrm{H}$ NMR $\left(400 \mathrm{MHz}, \mathrm{CDCl}_{3}\right) \delta=7.42(\mathrm{~d}, J=8.4 \mathrm{~Hz}, 2 \mathrm{H}), 7.18(\mathrm{~d}, J=8.4 \mathrm{~Hz}, 2 \mathrm{H}), 5.05(\mathrm{~m}, 1 \mathrm{H}), 3.73$ $(\mathrm{m}, 1 \mathrm{H}), 2.83-2.77(\mathrm{~m}, 1 \mathrm{H}), 2.74-2.69(\mathrm{~m}, 1 \mathrm{H}), 2.14(\mathrm{~s}, 3 \mathrm{H}) .{ }^{13} \mathrm{C} \mathrm{NMR}\left(100 \mathrm{MHz}, \mathrm{CDCl}_{3}\right) \delta=208.7$, $141.8,131.4,127.3,121.2,68.9,51.7,30.6$. The enantiomeric ratio $(88.4: 11.6)$ was determined by HPLC with Daicel chiral AS-H column at $262 \mathrm{~nm}$ (hexane $/ \mathrm{i} \mathrm{PrOH}=85 / 15$, flow rate $1.0 \mathrm{~mL} / \mathrm{min}$ ). $\mathrm{t}$ $($ major $)=11.0 \mathrm{~min}, \mathrm{t}(\operatorname{minor})=13.2 \mathrm{~min}$. 
4-hydroxy-4-(naphthalen-2-yl)butan-2-one ${ }^{5}$<smiles>CC(=O)CC(O)c1ccc2ccccc2c1</smiles>

${ }^{1} \mathrm{H}$ NMR $\left(400 \mathrm{MHz}, \mathrm{CDCl}_{3}\right) \delta=7.83(\mathrm{~m}, 4 \mathrm{H}), 7.57-7.40(\mathrm{~m}, 3 \mathrm{H}), 5.31(\mathrm{~m}, 1 \mathrm{H}), 3.61$ (brs, $\left.1 \mathrm{H}\right), 2.91$ $(\mathrm{m}, 2 \mathrm{H}), 2.19(\mathrm{~s}, 3 \mathrm{H}) .{ }^{13} \mathrm{C} \mathrm{NMR}\left(100 \mathrm{MHz}, \mathrm{CDCl}_{3}\right) \delta=209.0,140.1,133.2,132.8,128.2,127.9$, $127.6,126.1,125.8,124.3,123.7,69.8,51.8,30.7$. The enantiomeric ratio (91.4:8.6) was determined by HPLC with Daicel chiral AS-H column at $257 \mathrm{~nm}$ (hexane/ $\mathrm{i}-\mathrm{PrOH}=95 / 5$, flow rate $1.0 \mathrm{~mL} / \mathrm{min}) . \mathrm{t}$ (major) $=35.5 \mathrm{~min}, \mathrm{t}($ minor $)=40.4 \mathrm{~min}$.

\section{Recycle test of LZU-76}

The recyclability of LZU-76 was tested in the asymmetric aldol reaction by using acetone and 4-nitrobenzaldehyde as the substrates. After each cycle, LZU-76 was recovered by centrifugation, washed with $\mathrm{CH}_{2} \mathrm{Cl}_{2}(2 \times 6 \mathrm{~mL}), \mathrm{MeOH}$ (with $2 \%$ of $\left.\mathrm{Et}_{3} \mathrm{~N}\right)(2 \times 6 \mathrm{~mL}), \mathrm{H}_{2} \mathrm{O}(1 \times 6 \mathrm{~mL})$, THF $(1 \times 6$ $\mathrm{mL})$, and $\mathrm{Et}_{2} \mathrm{O}(1 \times 6 \mathrm{~mL})$. The resulting powder was dried at room temperature, and then used for the next cycle. The catalytic results were summarized in Table S5.

Table S5. Recycle test of LZU-76. ${ }^{a}$

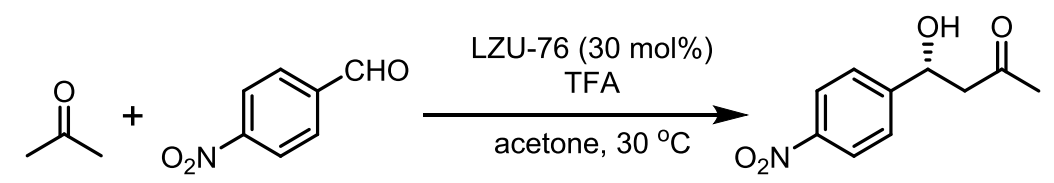

\begin{tabular}{cccc}
\hline entry & time $(\mathrm{h})$ & yield $(\%)^{b}$ & e.r. $^{c}$ \\
\hline Fresh & 18 & 73 & $94.0: 6.0$ \\
Cycle 1 & 18 & 64 & $93.1: 6.9$ \\
Cycle 2 & 18 & 62 & $92.9: 7.1$ \\
Cycle 3 & 18 & 55 & $93.3: 6.7$ \\
\hline
\end{tabular}

${ }^{a}$ General conditions: 4-nitrobenzaldehyde $(0.20 \mathrm{mmol}), \mathrm{LZU}-76(0.06 \mathrm{mmol})$, TFA (0.06 mmol), acetone $(1.0 \mathrm{~mL}) .{ }^{b}$ Isolated yield. ${ }^{\circ}$ Determined by chiral HPLC (Daicel chiral AS-H). 


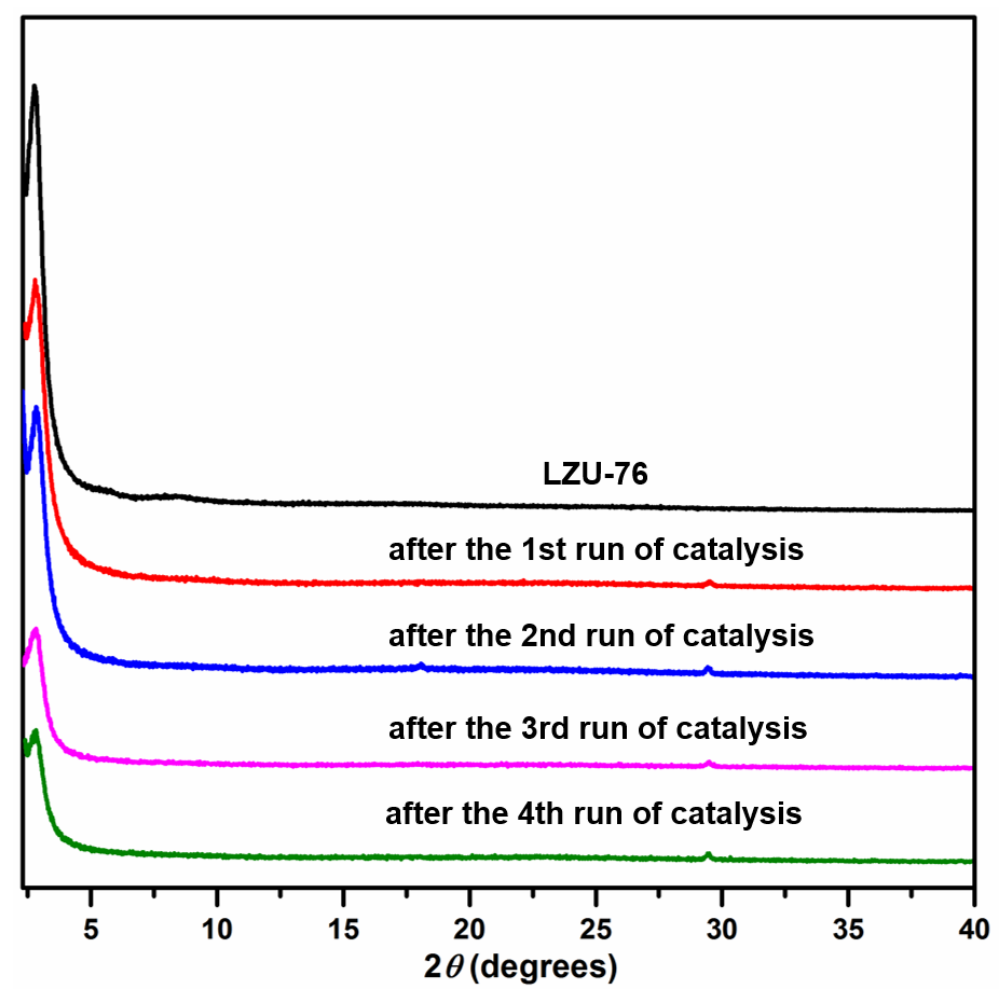

Figure S57. PXRD patterns of LZU-76 (black), LZU-76 after the first (red), second (blue), third (pink), and fourth (green) runs of catalysis. The comparison of the PXRD patterns after different reaction runs indicates that the crystallinity of LZU-76 was almost maintained, although the intensity of the PXRD patterns was gradually decreased. The decrease of the crystallinity could be attributed to the repetitive exposure of LZU-76 to the strong acid (TFA) during the catalytic process.

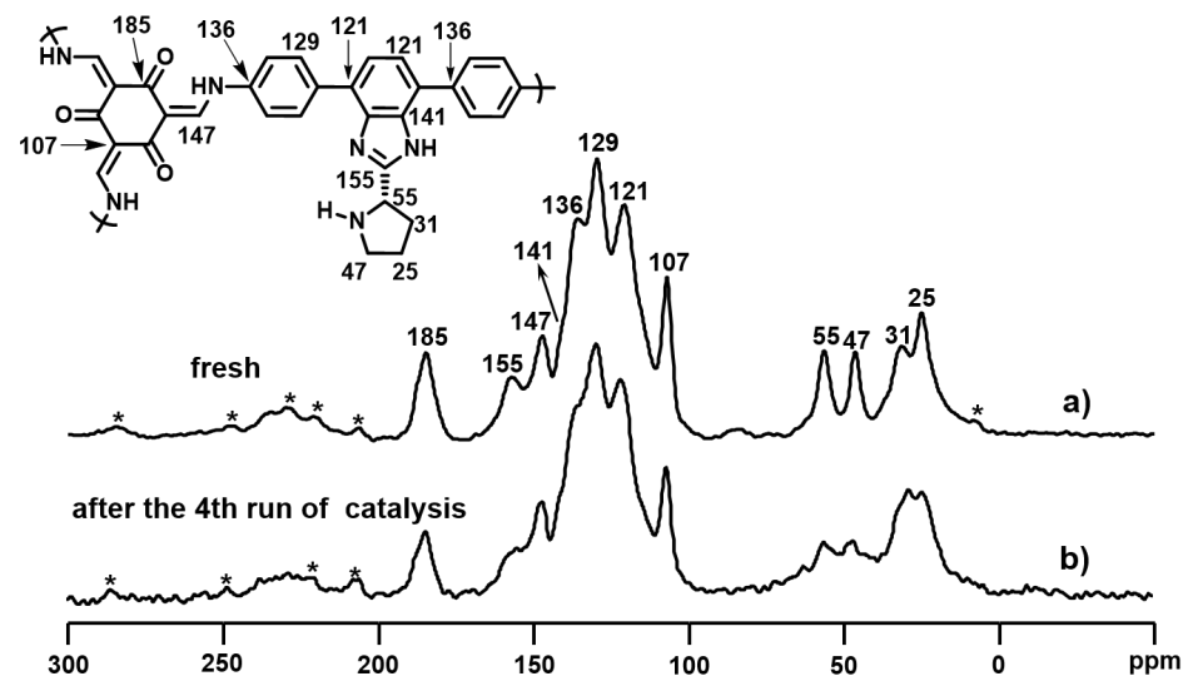

Figure S58. ${ }^{13} \mathrm{C}$ CP/MAS NMR spectra of LZU-76 (a) and LZU-76 after the 4th cycle use (b). The

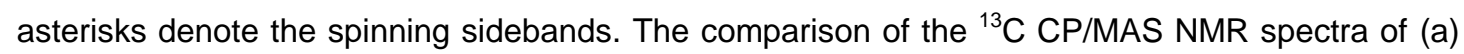
and (b) indicates that the molecular structure of LZU-76 was well maintained during the recycle use. 


\section{References}

1. Oisaki, K.; Li, Q.; Furukawa, H.; Czaja, A. U.; Yaghi, O. M. J. Am. Chem. Soc. 2010, 132, 9262.

2. Zhang, B.; Jiang, Z.; Zhou, X.; Lu, S.; Li, J.; Liu, Y.; Li, C. Angew. Chem., Int. Ed. 2012, 51, 13159.

3. Materials Studio v.7.0 (Accelrys Software, San Diego, 2013).

4. (a) Spitler, E. L.; Koo, B. T.; Novotney, J. L.; Colson, J. W.; Uribe-Romo, F. J.; Gutierrez, G. D.; Clancy, P.; Dichtel, W. R. J. Am. Chem. Soc. 2011, 133, 19416. (b) Dalapati, S.; Jin, E.; Addicoat, M.; Heine, T.; Jiang, D. J. Am. Chem. Soc. 2016, 138, 5797.

5. Gruttadauria, M.; Giacalone, F.; Marculescu, A. M.; Noto, R. Adv. Synth. Catal. 2008, 350, 1397.

6. Wang, B.; Liu, X.-w.; Liu, L.-y.; Chang, W.-x.; Li, J. Eur. J. Org. Chem. 2010, 5951. 
10. Liquid ${ }^{1} \mathrm{H}$ and ${ }^{13} \mathrm{C}$ NMR Spectra
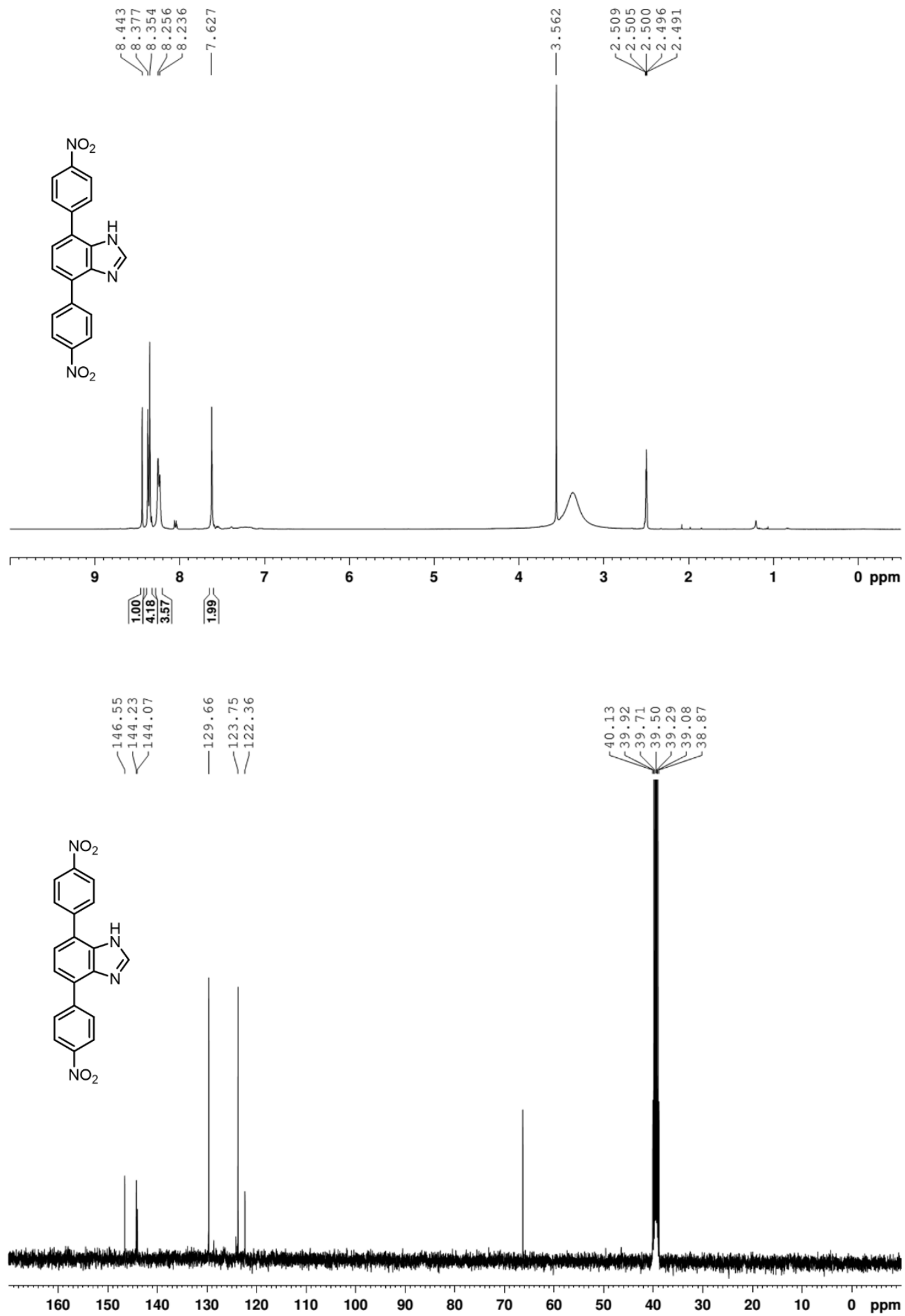

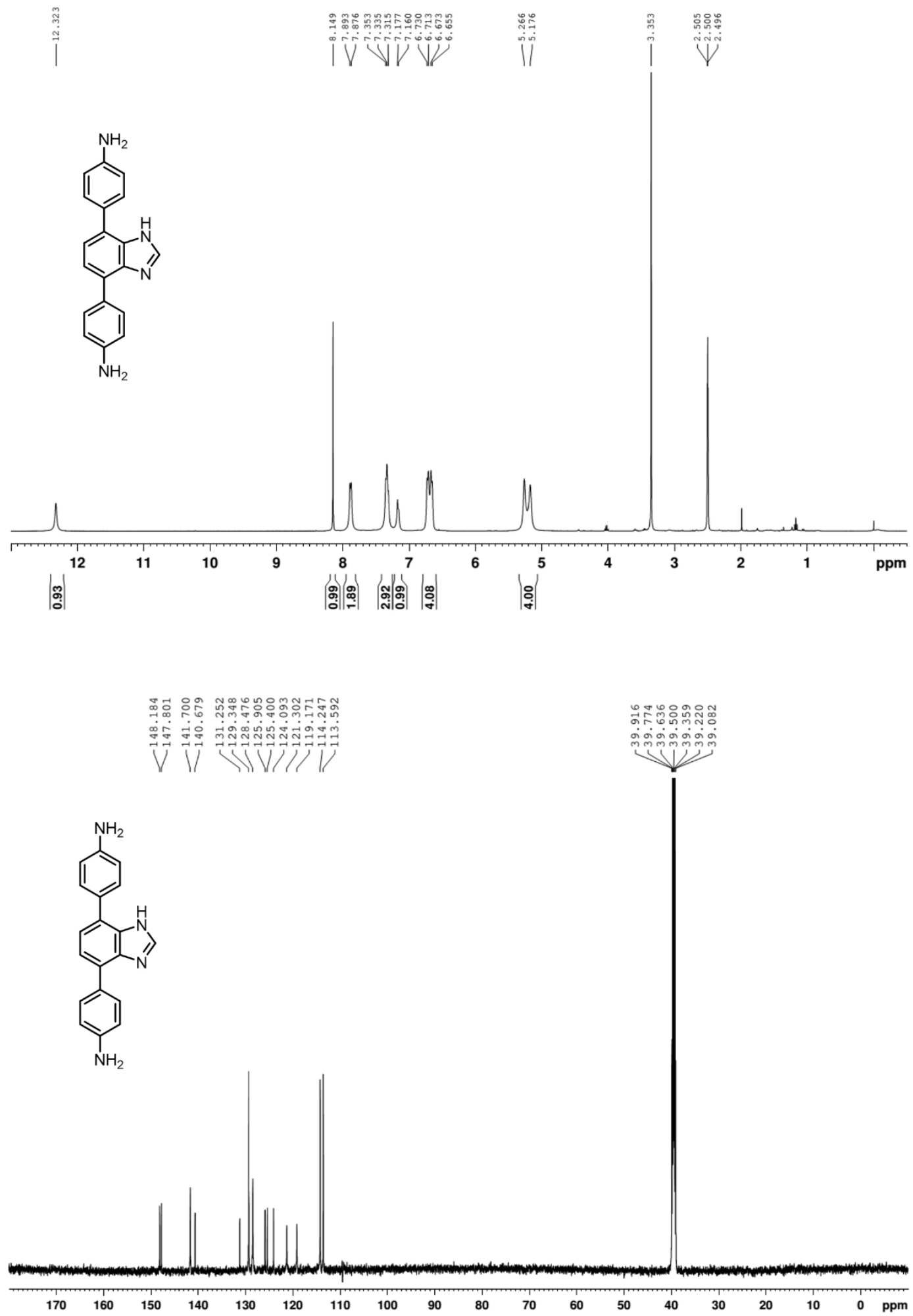


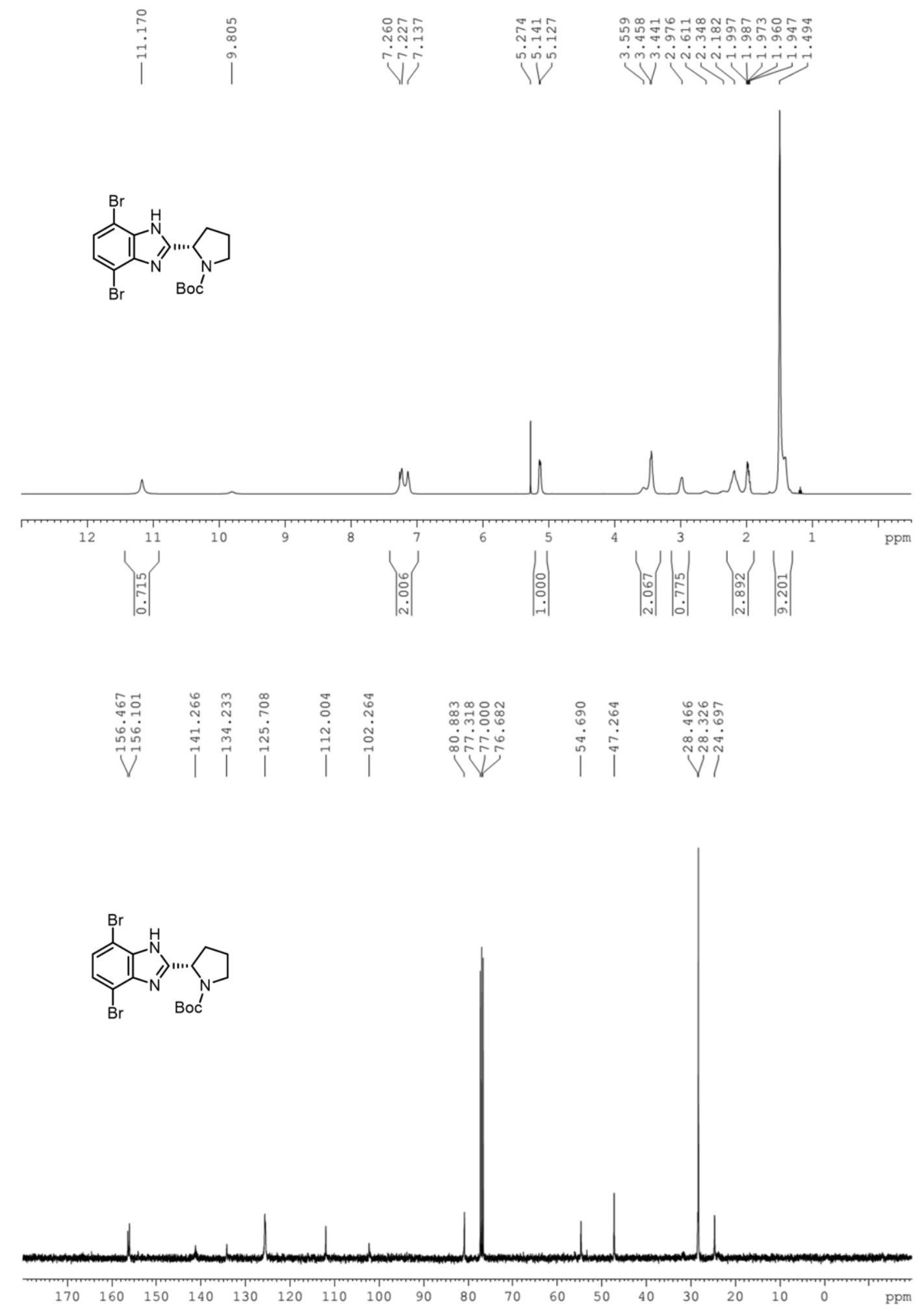




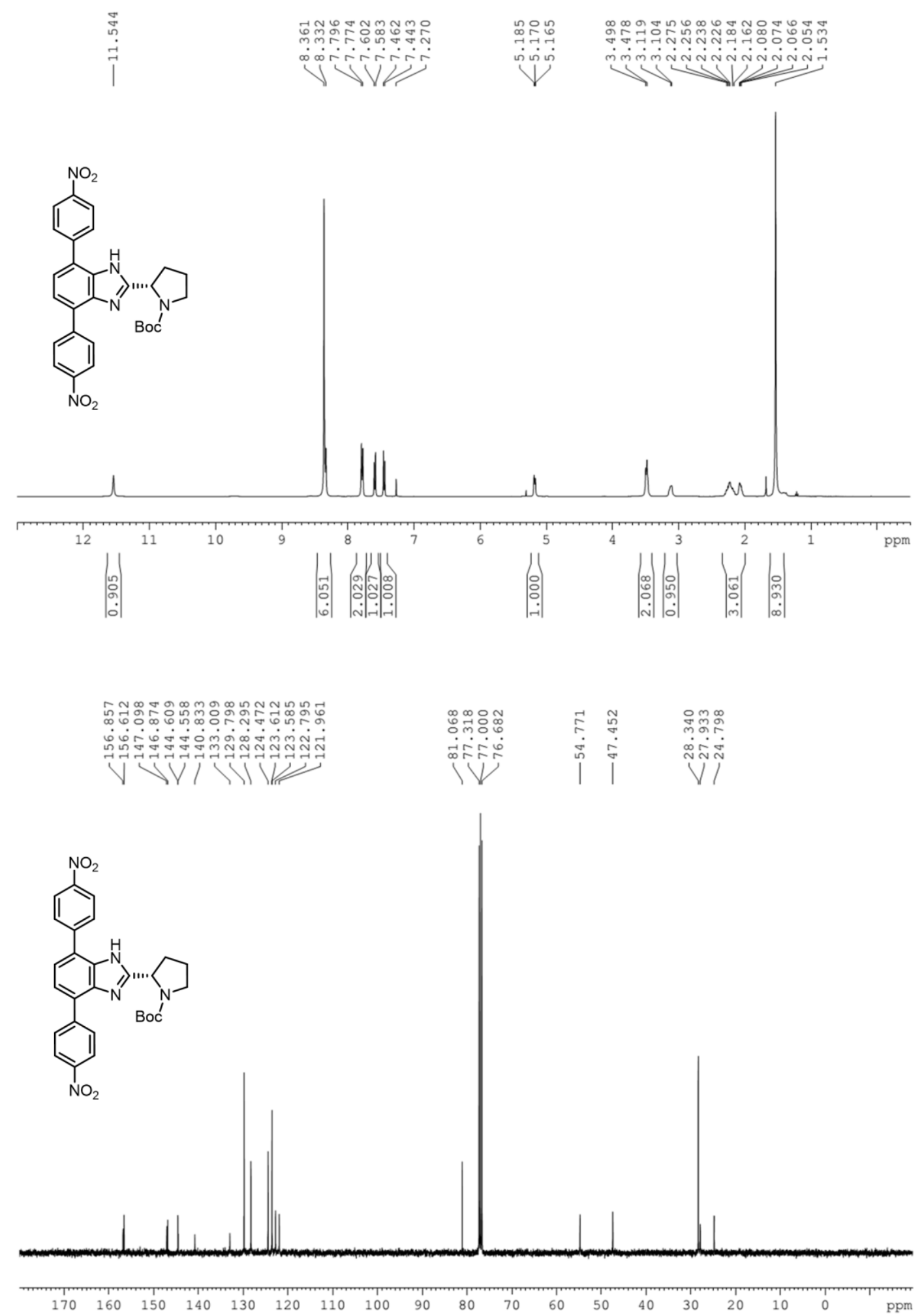


<smiles>Nc1ccc(-c2ccc(-c3ccc(N)cc3)c3[nH]c([C@H]4CCCN4C(=O)c4ccccc4)nc23)cc1</smiles>

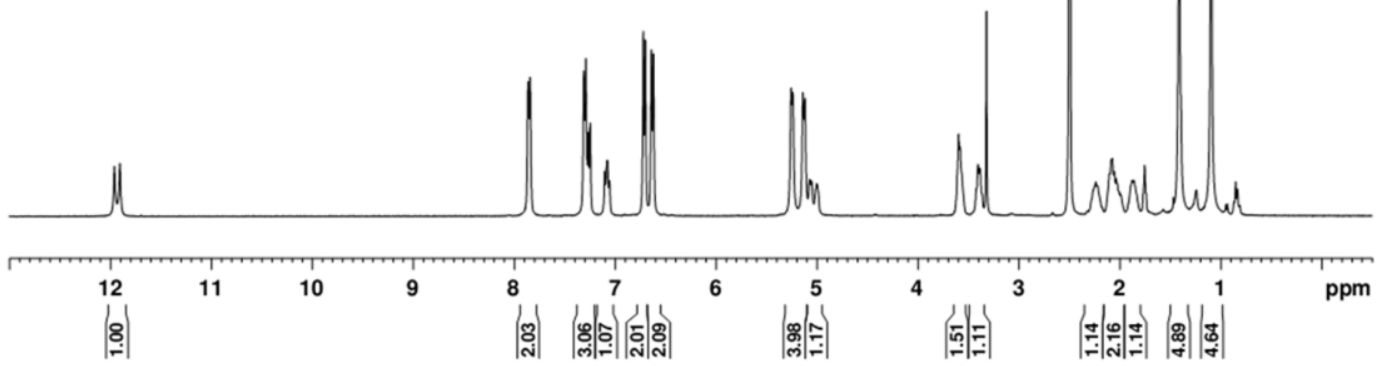

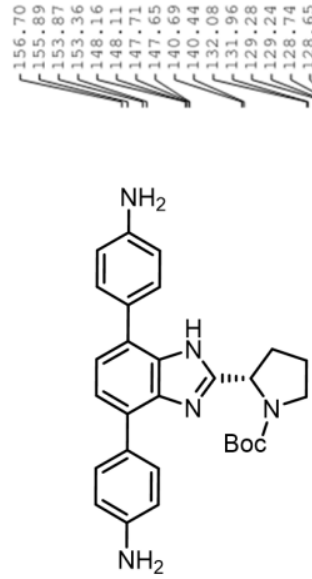

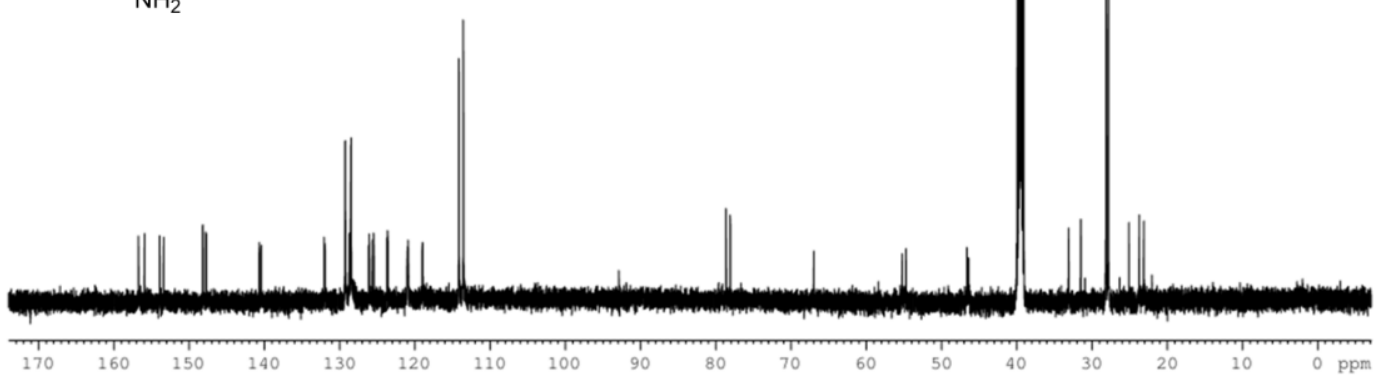




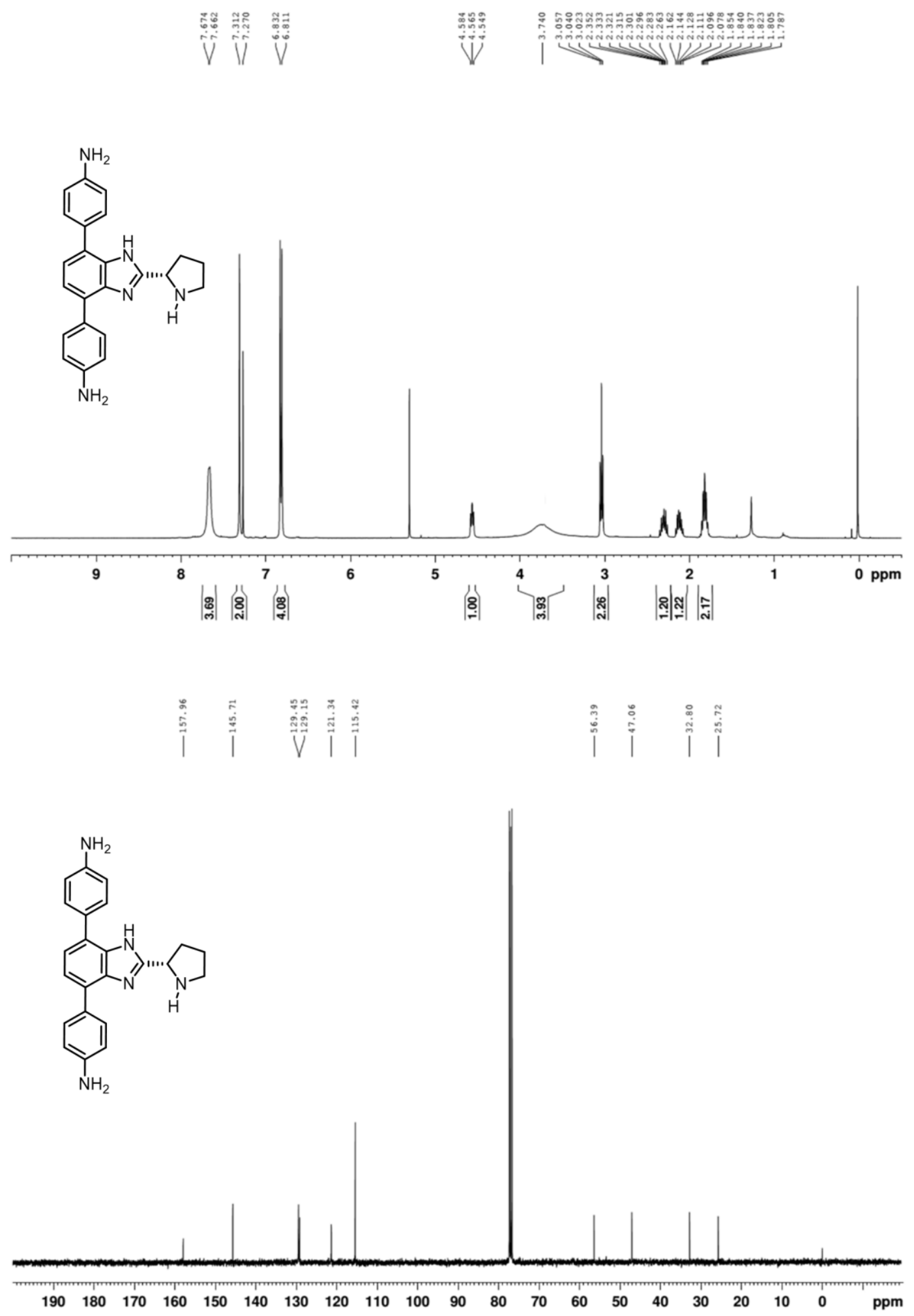




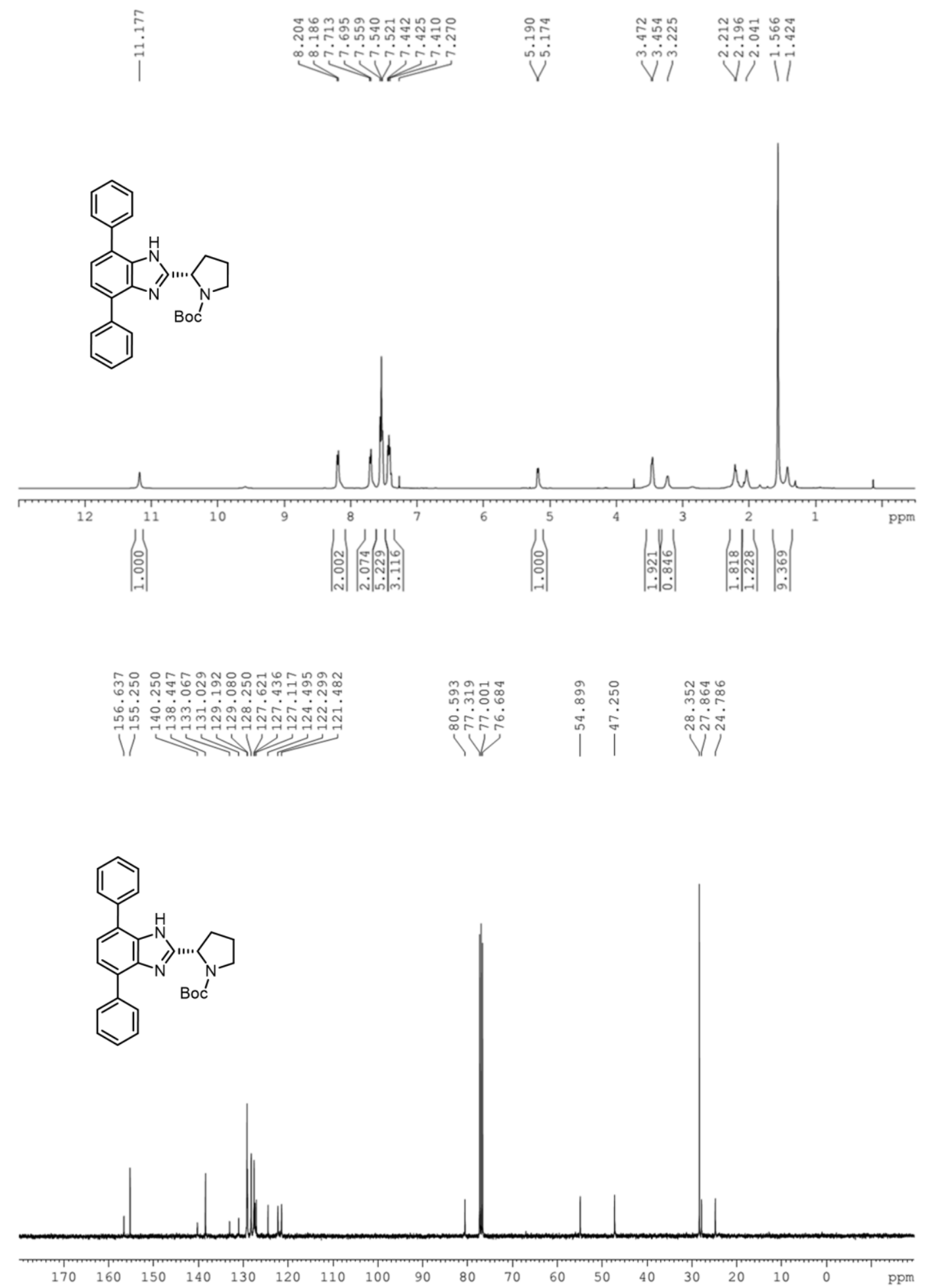




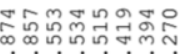

irriritin

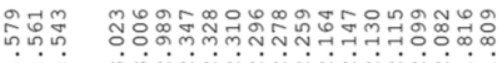

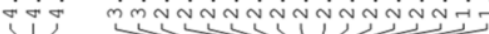<smiles>c1ccc(-c2ccc(-c3ccccc3)c3[nH]c([C@@H]4CCCN4)nc23)cc1</smiles>

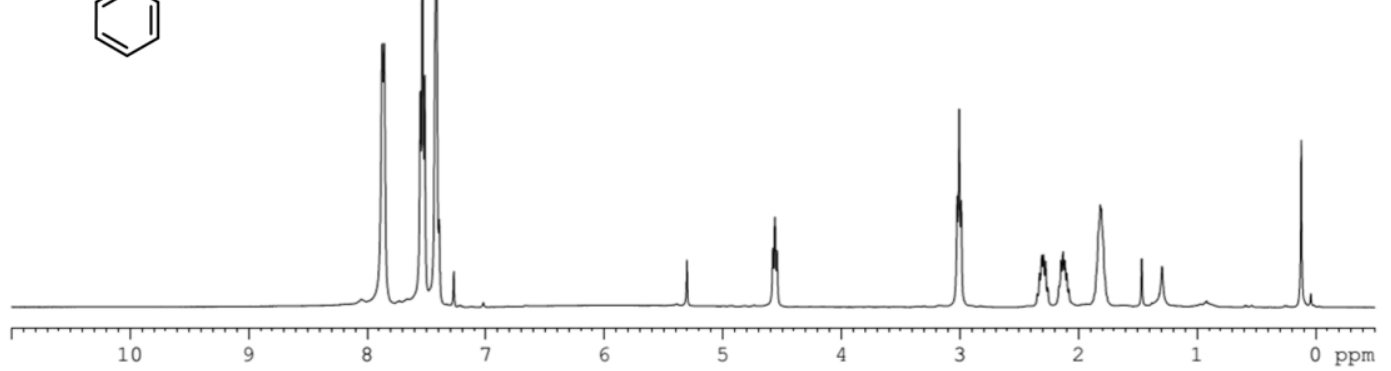

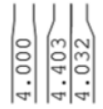

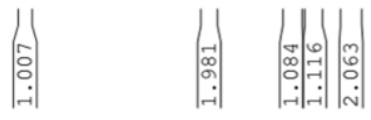

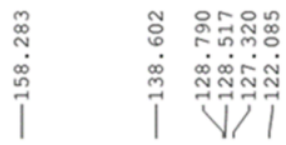

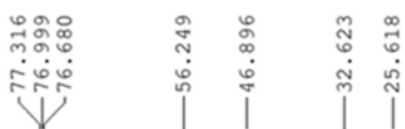

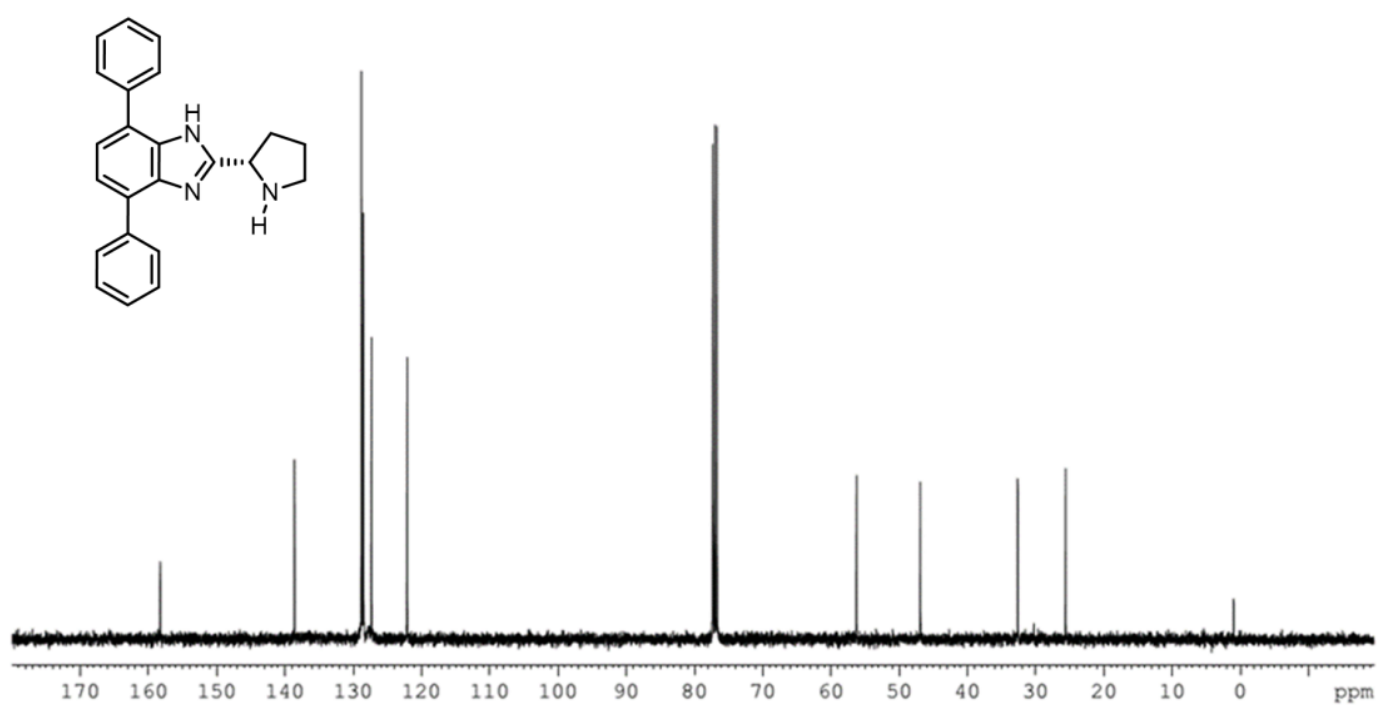




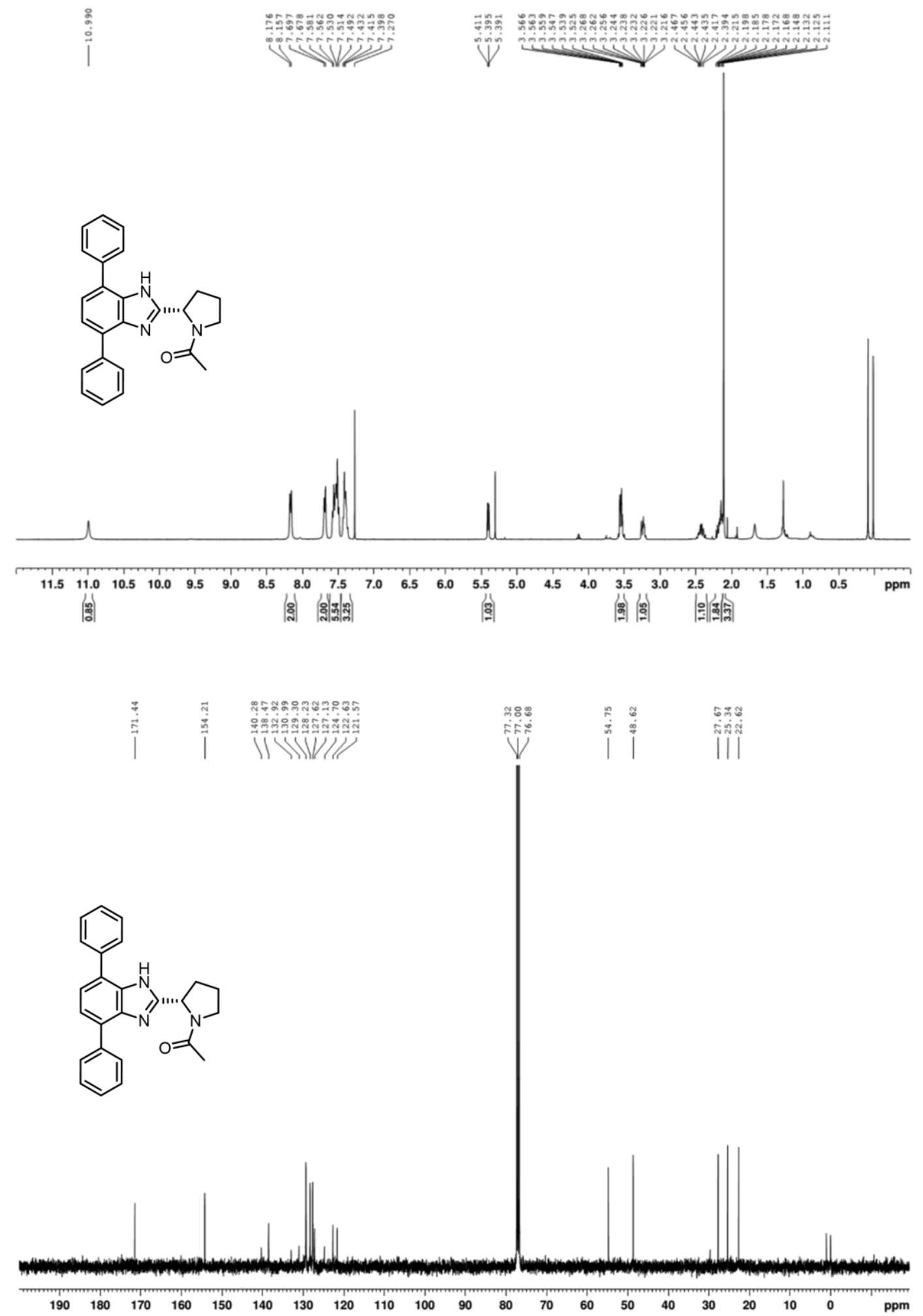




\section{HPLC Spectra}
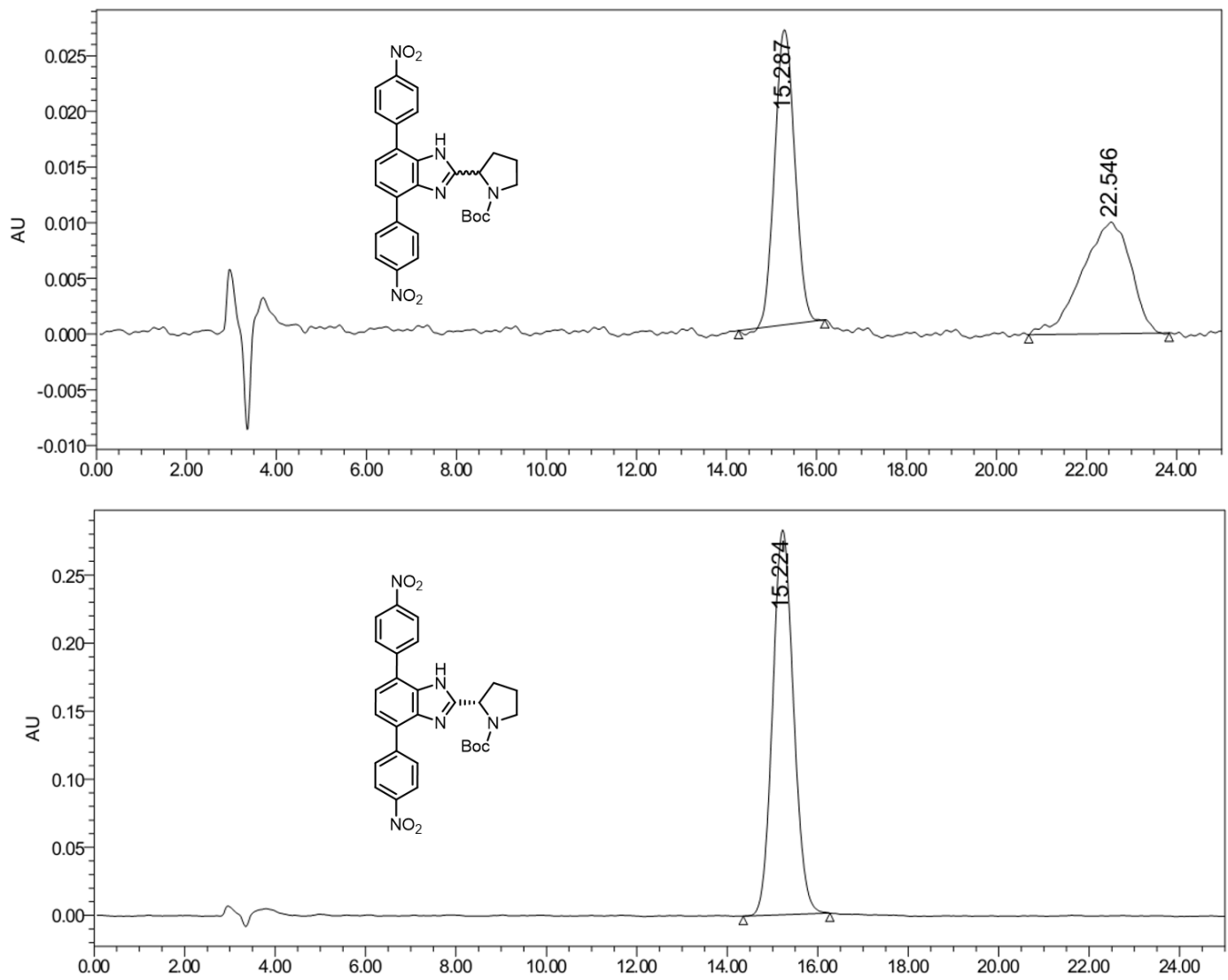

\begin{tabular}{|c|c|c|c|c|}
\hline & $\begin{array}{c}\text { Retention Time } \\
\text { (minute) }\end{array}$ & $\begin{array}{c}\text { Area } \\
\left.\text { (microvolt }{ }^{*} \text { sec. }\right)\end{array}$ & $\begin{array}{c}\text { Relative Area } \\
(\%)\end{array}$ & $\begin{array}{c}\text { Height } \\
\text { (microvolt) }\end{array}$ \\
\hline 1 & 15.224 & 9081557 & 100 & 282685 \\
\hline
\end{tabular}



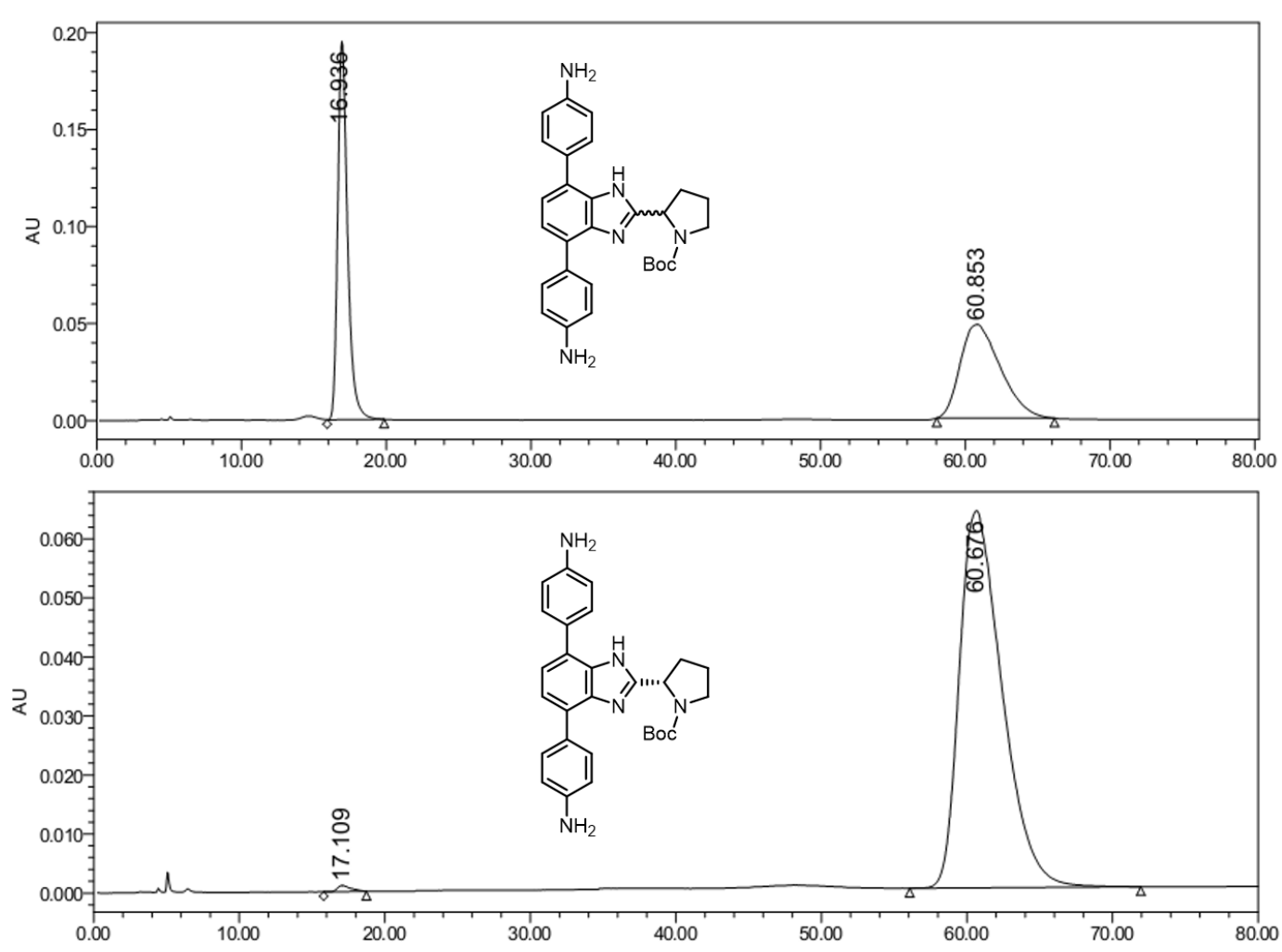

\begin{tabular}{|c|c|c|c|c|}
\hline & $\begin{array}{c}\text { Retention Time } \\
\text { (minute) }\end{array}$ & $\begin{array}{c}\text { Area } \\
\text { (microvolt*sec.) }\end{array}$ & $\begin{array}{c}\text { Relative Area } \\
(\%)\end{array}$ & $\begin{array}{c}\text { Height } \\
\text { (microvolt) }\end{array}$ \\
\hline 1 & 17.109 & 65601 & 0.50 & 1034 \\
\hline 2 & 60.676 & 13044677 & 99.50 & 63877 \\
\hline
\end{tabular}



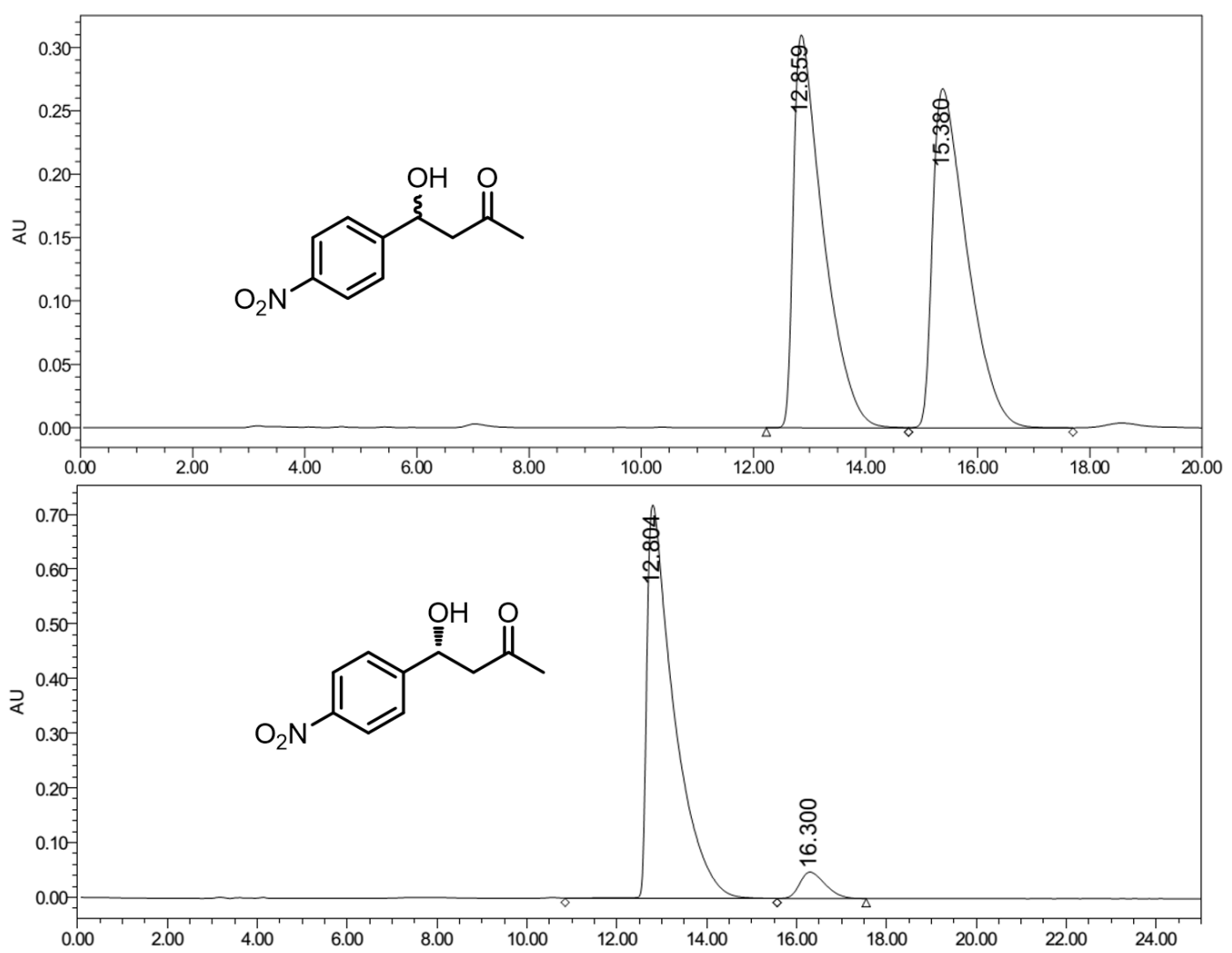

\begin{tabular}{|c|c|c|c|c|}
\hline & $\begin{array}{c}\text { Retention Time } \\
\text { (minute) }\end{array}$ & $\begin{array}{c}\text { Area } \\
\text { (microvolt*sec.) }\end{array}$ & $\begin{array}{c}\text { Relative Area } \\
(\%)\end{array}$ & $\begin{array}{c}\text { Height } \\
\text { (microvolt) }\end{array}$ \\
\hline 1 & 12.804 & 30117559 & 94.01 & 720149 \\
\hline 2 & 16.300 & 1919574 & 5.99 & 48419 \\
\hline
\end{tabular}



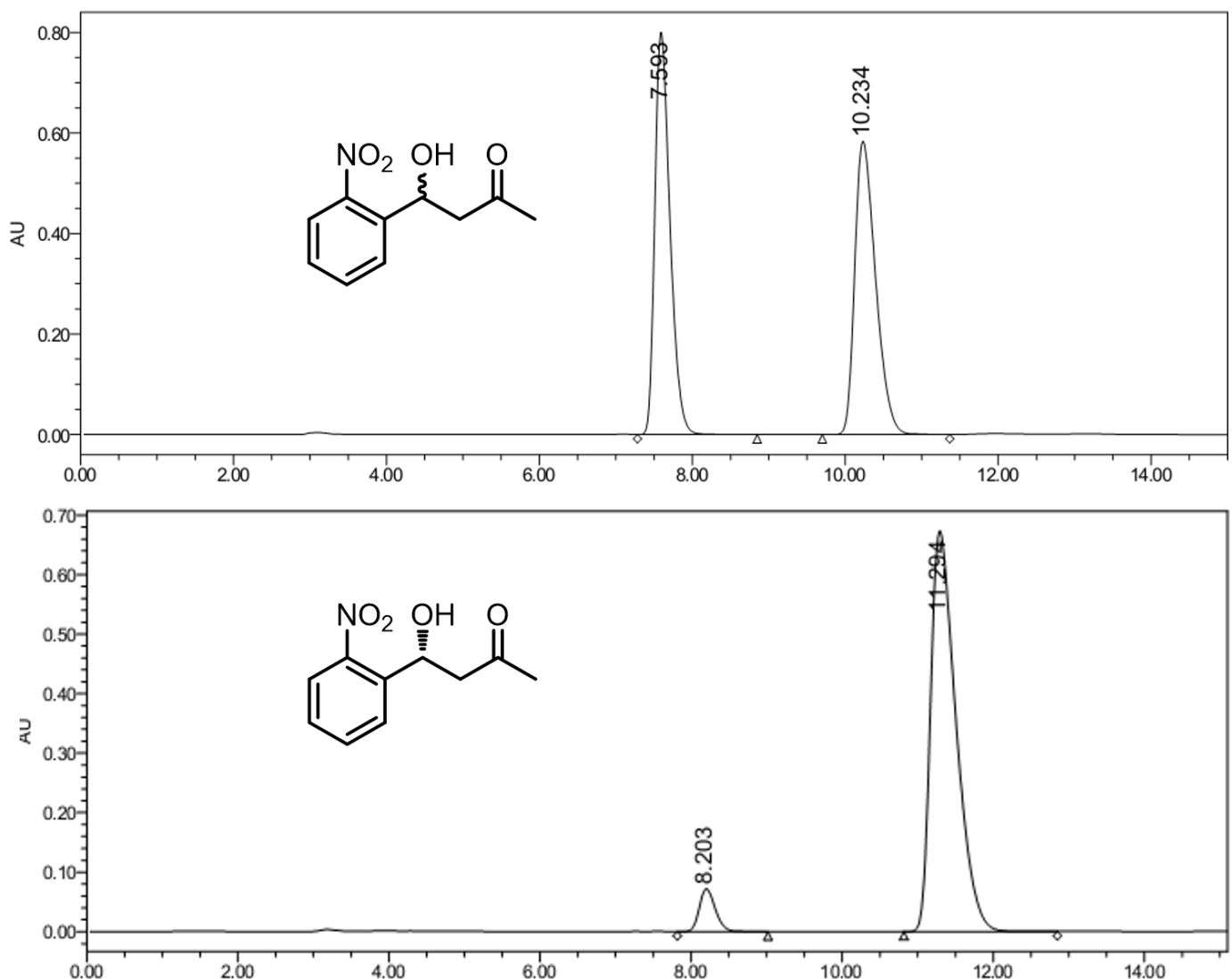

\begin{tabular}{|c|c|c|c|c|}
\hline & $\begin{array}{c}\text { Retention Time } \\
\text { (minute) }\end{array}$ & $\begin{array}{c}\text { Area } \\
\text { (microvolt*sec.) }\end{array}$ & $\begin{array}{c}\text { Relative Area } \\
(\%)\end{array}$ & $\begin{array}{c}\text { Height } \\
\text { (microvolt) }\end{array}$ \\
\hline 1 & 8.203 & 1062227 & 6.33 & 71897 \\
\hline 2 & 11.294 & 15714171 & 93.67 & 673665 \\
\hline
\end{tabular}



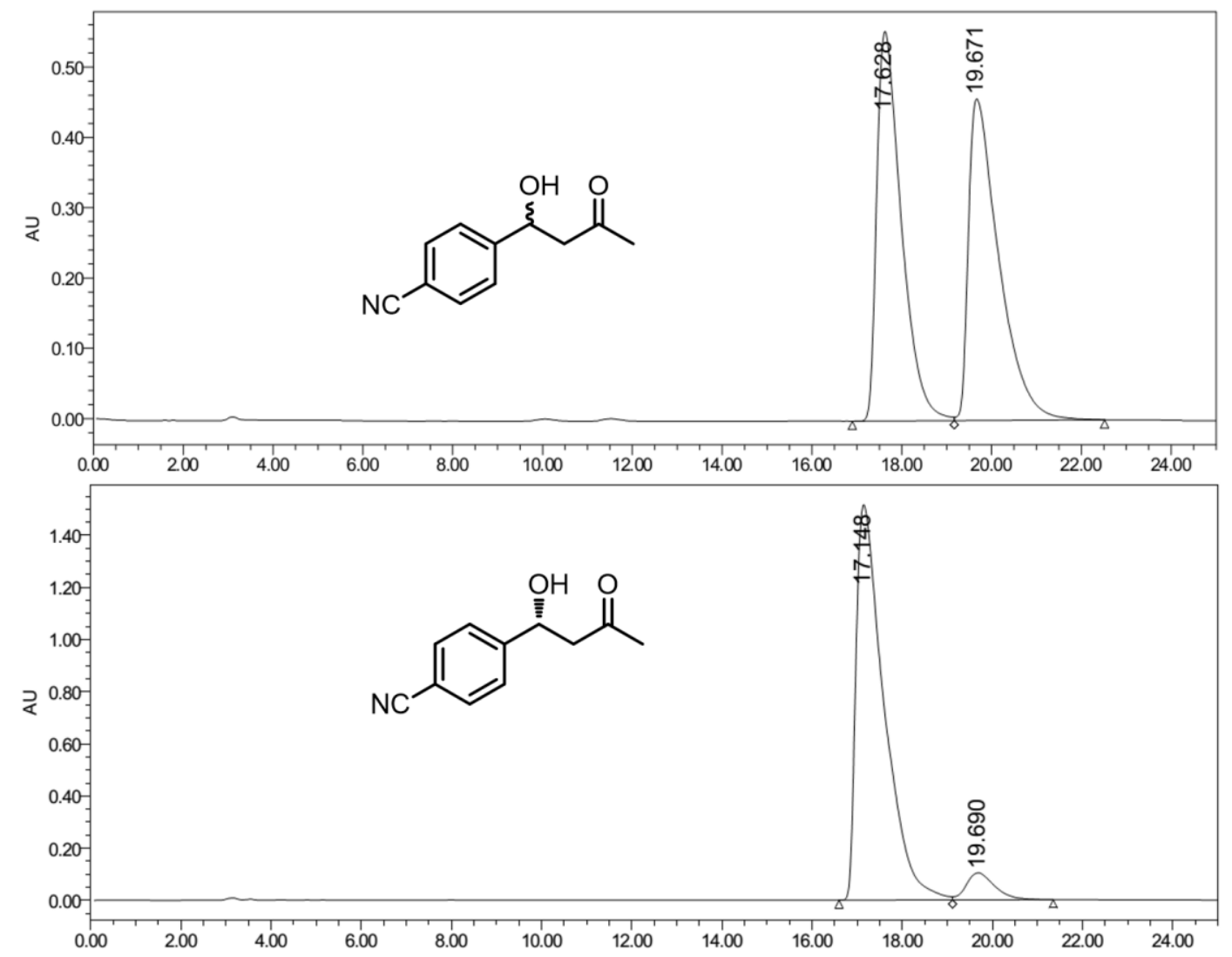

\begin{tabular}{|c|c|c|c|c|}
\hline & $\begin{array}{c}\text { Retention Time } \\
\text { (minute) }\end{array}$ & $\begin{array}{c}\text { Area } \\
\text { (microvolt*sec.) }\end{array}$ & $\begin{array}{c}\text { Relative Area } \\
(\%)\end{array}$ & $\begin{array}{c}\text { Height } \\
\text { (microvolt) }\end{array}$ \\
\hline 1 & 17.148 & 65444721 & 93.54 & 1516450 \\
\hline 2 & 19.690 & 4521411 & 6.46 & 103455 \\
\hline
\end{tabular}



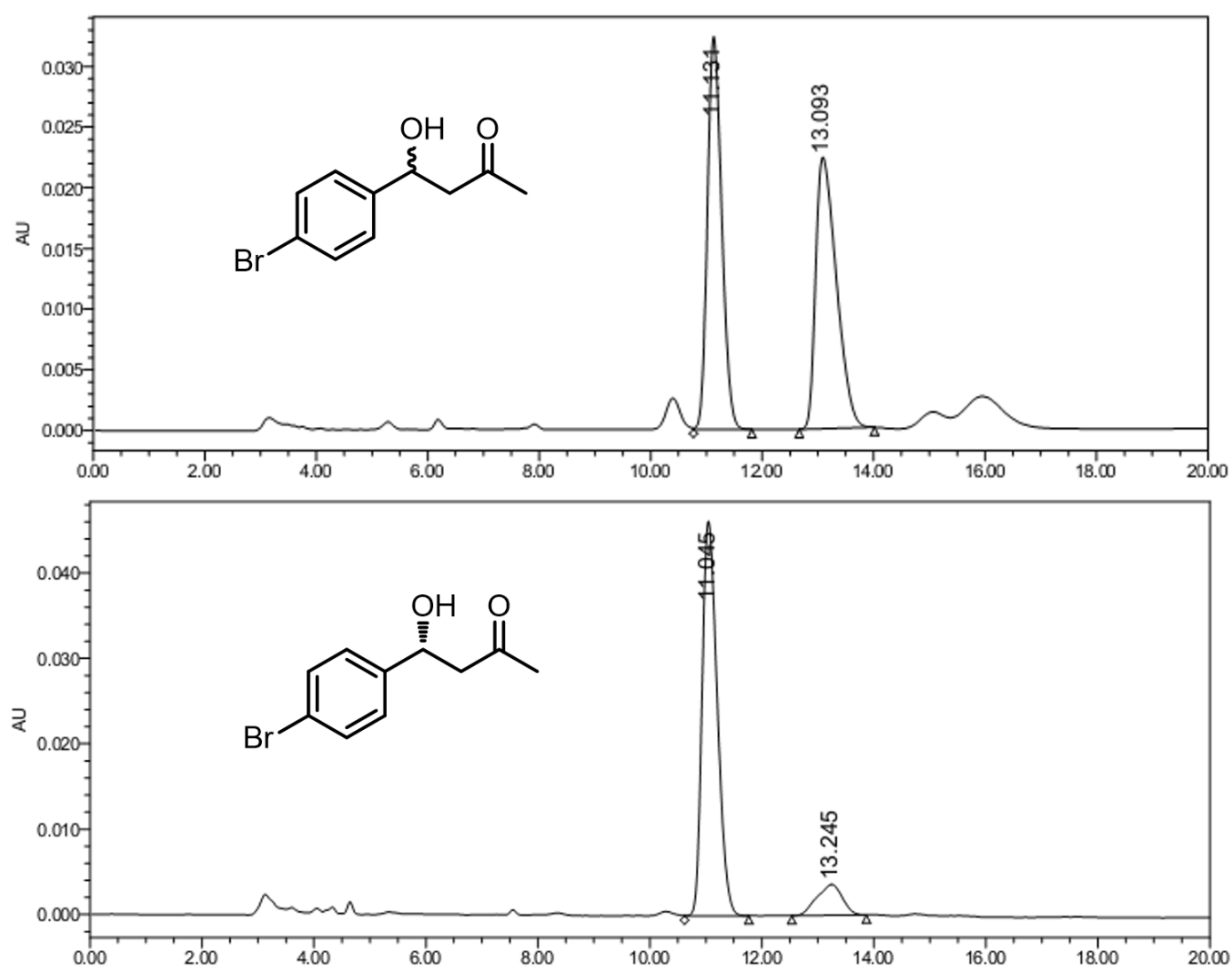

\begin{tabular}{|c|c|c|c|c|}
\hline & $\begin{array}{c}\text { Retention Time } \\
\text { (minute) }\end{array}$ & $\begin{array}{c}\text { Area } \\
\text { (microvolt*sec.) }\end{array}$ & $\begin{array}{c}\text { Relative Area } \\
(\%)\end{array}$ & $\begin{array}{c}\text { Height } \\
\text { (microvolt) }\end{array}$ \\
\hline 1 & 11.045 & 864568 & 88.37 & 46249 \\
\hline 2 & 13.245 & 113837 & 11.63 & 3606 \\
\hline
\end{tabular}



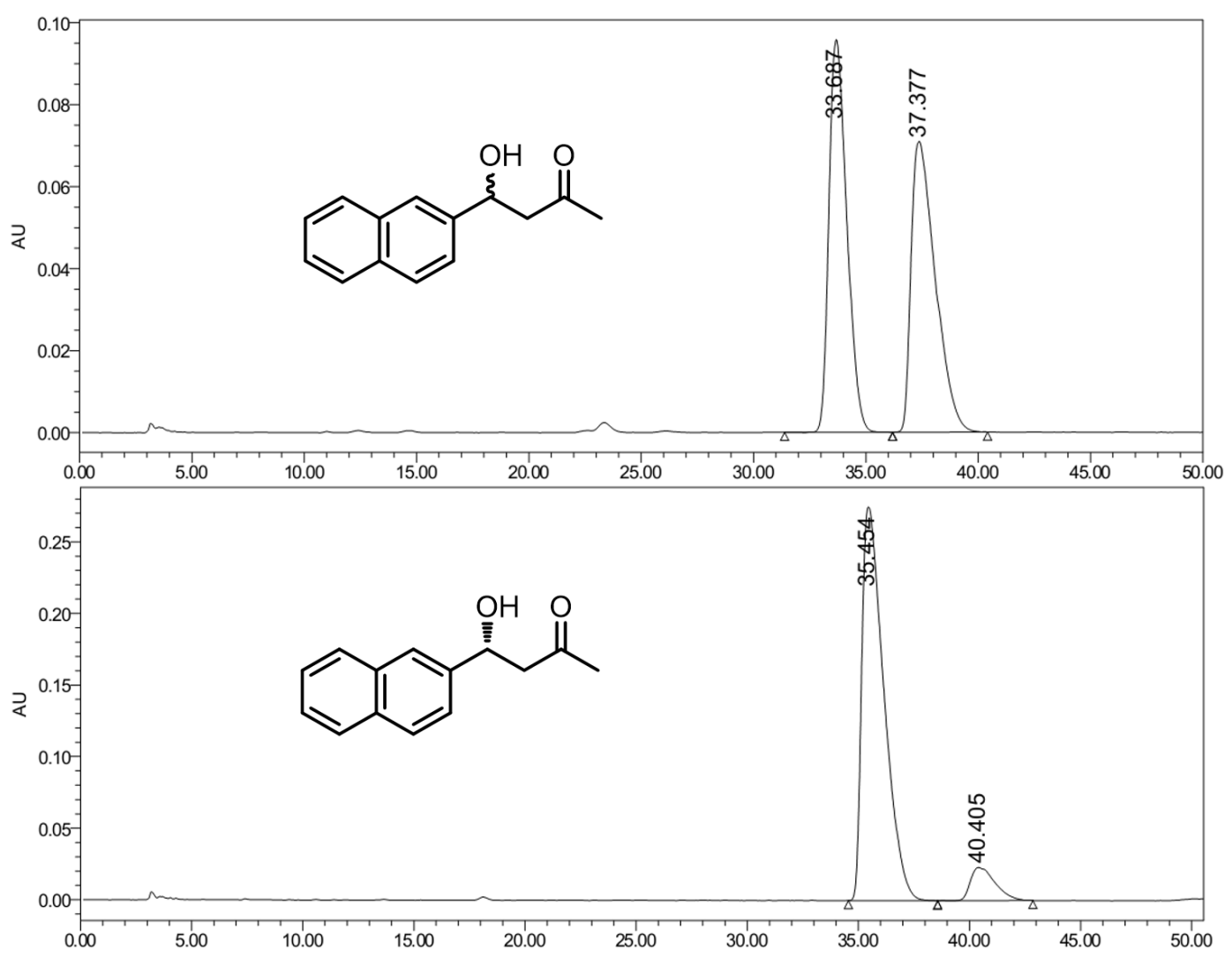

\begin{tabular}{|c|c|c|c|c|}
\hline & $\begin{array}{c}\text { Retention Time } \\
\text { (minute) }\end{array}$ & $\begin{array}{c}\text { Area } \\
\text { (microvolt*sec.) }\end{array}$ & $\begin{array}{c}\text { Relative Area } \\
(\%)\end{array}$ & $\begin{array}{c}\text { Height } \\
\text { (microvolt) }\end{array}$ \\
\hline 1 & 35.454 & 19007463 & 91.38 & 274952 \\
\hline 2 & 40.405 & 1793843 & 8.62 & 23151 \\
\hline
\end{tabular}

